\title{
大豆蛋白啠に就て (蛋白質の研究，第十三報）
}

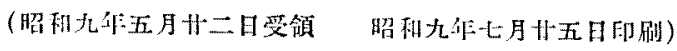

日比里正形有

\section{緒論}

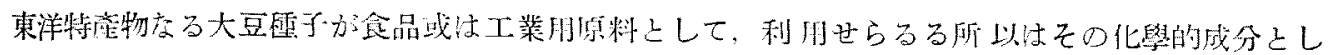

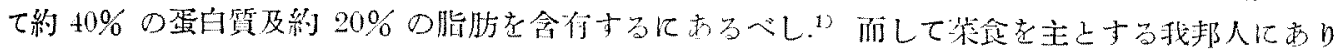

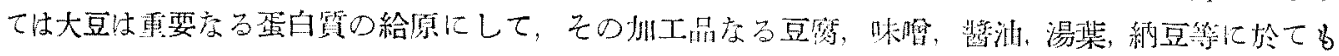

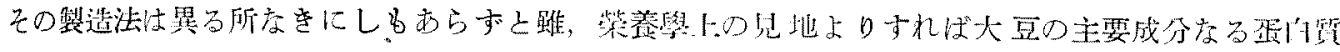

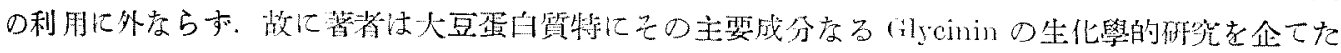
b.

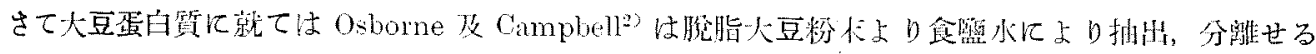

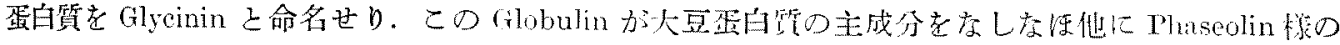

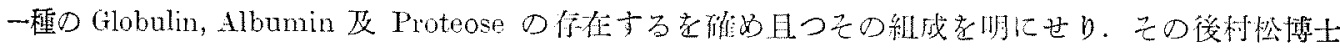

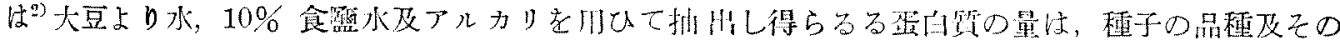

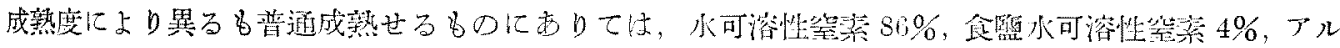

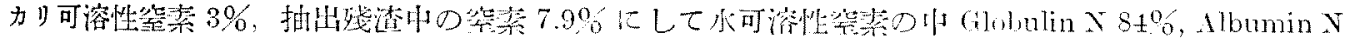

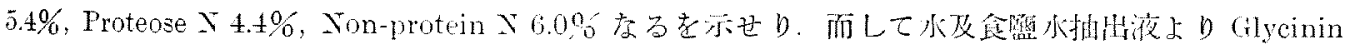
及 Phaseolin 庆る二種の Globulin, Lerumdin 及 Royluzumelin なる二掹の Albunin 及 Proteose を

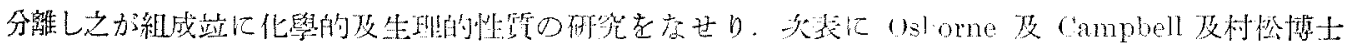
の研究成紹を示せり。

\begin{tabular}{|c|c|c|c|c|c|c|c|c|c|}
\hline & \multicolumn{4}{|c|}{ Osborne \& Campbell } & \multicolumn{3}{|c|}{ 朴 } & \multicolumn{2}{|l|}{ 松 } \\
\hline & Legunelin & Glycinin & Phaseolin & Proteose & Legrumelin & $\begin{array}{l}\text { Soylegn- } \\
\text { melin }\end{array}$ & Glyoinin & Phaseolin & Protense \\
\hline $\mathrm{C}$ & 53.06 & $\begin{array}{r}\% \\
52.12\end{array}$ & $\begin{array}{r}\% \\
51.94\end{array}$ & 48.76 & 53.12 & $\begin{array}{r}\% \\
5268\end{array}$ & 51.87 & $\begin{array}{r}\% \\
51.80\end{array}$ & $\begin{array}{r}\% \\
48.69\end{array}$ \\
\hline $\mathrm{H}$ & 6.94 & 6.93 & 6.88 & 6.28 & 6.73 & 6.79 & 6.81 & 6.94 & 6.10 \\
\hline $\mathrm{N}$ & 16.14 & 17.53 & 16.51 & 16.14 & 16.27 & 15.14 & 17.71 & 16.45 & 16.60 \\
\hline 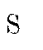 & 1.17 & 0.79 & 0.60 & - & 1.04 & 0.29 & 0.78 & 0.42 & - \\
\hline
\end{tabular}

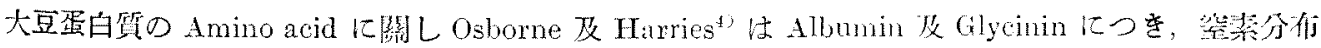

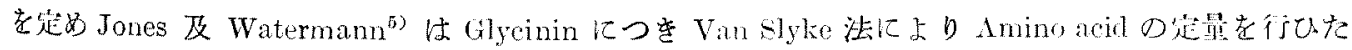

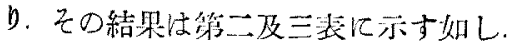

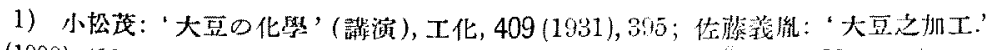
$20(1898), 419 . \quad 3)$ 本誌, 41 (1920), 311. 4) J. Am. Chem. Soce, 25 (1903), 823. (1921), 459 .
2) J. Am. Chem. Suc., 5) J. Biol. (hem., 46 
第二表等菜分杖

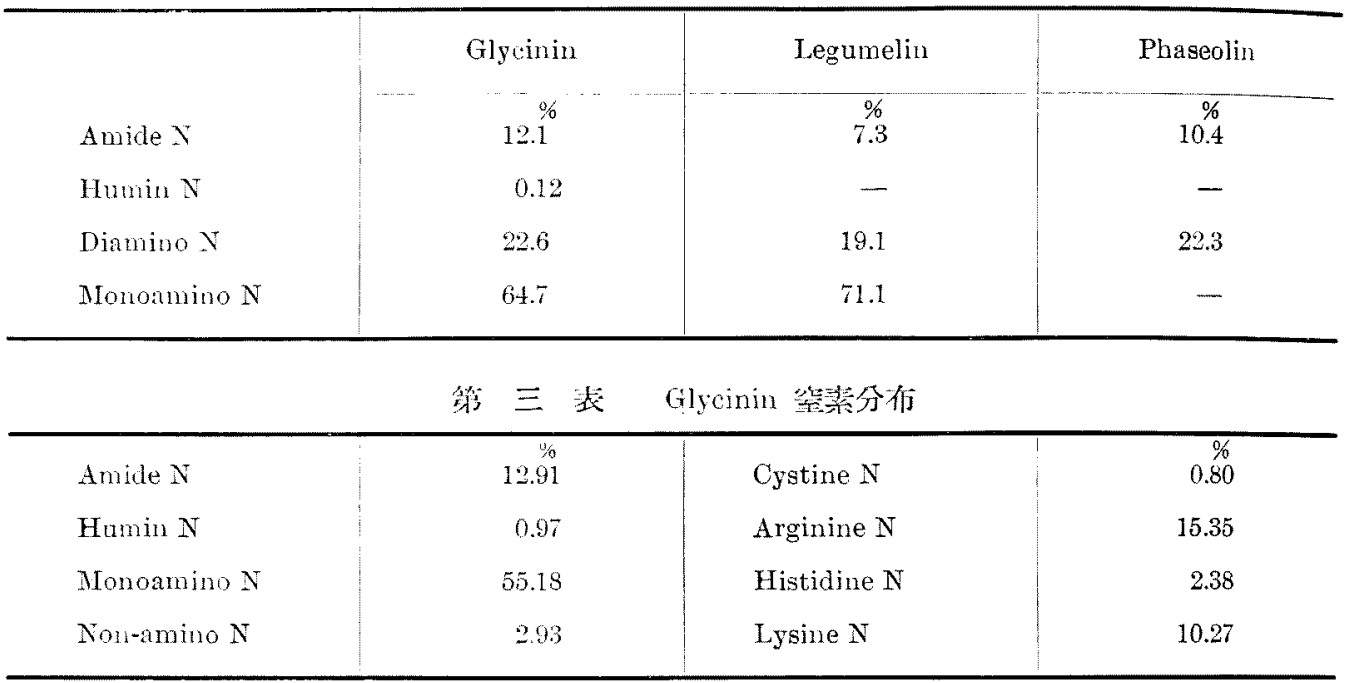

Osbome 及 Clapp は Glycinin の各 Amino acid の是量を行U May 及 Rose Tryptophan 会量を, Jones, Gersdorf 及 Moeller は Tryptophan 及 Cystin の量を定めたるがその結 果は己考第四表机示せり。

\begin{tabular}{|c|c|c|c|c|}
\hline \multirow[b]{2}{*}{ G]ycoroll } & \multicolumn{2}{|c|}{$\begin{array}{c}\text { Glycinin } \\
\text { (Osborne \& Clapp) }\end{array}$} & \multicolumn{2}{|c|}{ Casein** } \\
\hline & $1 . \%$ & ${ }_{2}$ 分子比 & $0^{\%}$ & 分子比 \\
\hline Alanine & - & - & 1.5 & 3 \\
\hline Taline & 0.68 & 1 & 7.2 & 11 \\
\hline Leucine & 8.45 & 11 & 9.4 & 12 \\
\hline Proline & 3.78 & 5 & 6.7 & 11 \\
\hline Phenglalauine & 3.83 & 4 & 3.2 & 4 \\
\hline Tyrosine & 1.85 & 2 & 4.5 & 4 \\
\hline Serine & - & - & 0.5 & - \\
\hline Aspartic acid & 3.85 & $\tilde{0}$ & 1.4 & 2 \\
\hline Glutamie acid & 19.46 & 22 & $1 \overline{0.6}$ & 20 \\
\hline Argiuine & 5.12 & $\tilde{5}$ & 3.8 & 4 \\
\hline Histidiue & 1.39 & 2 & 3.4 & 4 \\
\hline Lysine & 2.71 & 3 & 8.3 & 10 \\
\hline Cystiue & $1.12^{*}$ & 2 & - & - \\
\hline Trsptophave & $1.65^{*}$ & 2 & 2.0 & 2 \\
\hline Ammonia & 2.56 & & 1.6 & \\
\hline
\end{tabular}

* Jones, Gersdorf \& Moeller.

** Kestner: 'Chemie der Eiweiszkörper' (1925), 304.

分子比忙

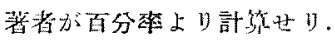

1) Z. Anatyt. Chem., 48 (1909), 623.

2) J. Biol. Chem , 54 (1922), 213.

3) J. Biol. Chem., 62 (1924), 183. 


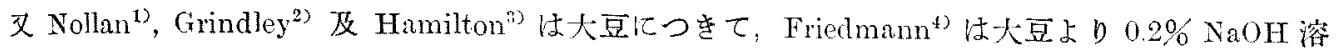

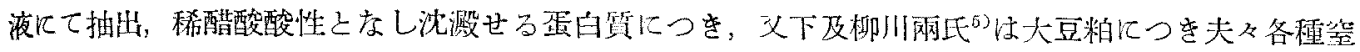
素の定量をなしたり，その絬果は己を欲五表に總括せり。

第 五表大豆及大豆粕空素分有

\begin{tabular}{|c|c|c|c|c|c|}
\hline & $\begin{array}{l}\text { Friedmann } \\
\text { (大至蛋白) }\end{array}$ & $\begin{array}{l}\text { Nollan } \\
\text { (大豆) }\end{array}$ & $\begin{array}{c}\text { Grindley } \\
\text { (大豆) }\end{array}$ & $\begin{array}{c}\text { Hamilton } \\
\text { (大豆) }\end{array}$ & $\begin{array}{l}\text { 下，柳川 } \\
\text { (大豆粕) }\end{array}$ \\
\hline Amide $\Sigma$ & $\begin{array}{r}\% \\
11.31\end{array}$ & 12.97 & $\begin{array}{r}\% \\
10.12\end{array}$ & $\begin{array}{r}\% \\
9.38\end{array}$ & 10.00 \\
\hline Humin 5 & 1.84 & 3.69 & 6.63 & 2.87 & 4.83 \\
\hline Diamino $N$ & : & & & 28.94 & 26.43 \\
\hline Cystine $\mathrm{N}$ & 1.04 & 1.52 & 0.67 & 1.46 & \\
\hline Arginine $\mathrm{N}$ & $14.5 \bar{i}$ & 15.52 & 12.67 & 15.70 & \\
\hline Histidine $\mathrm{X}$ & 5.92 & 2.60 & 5.77 & 5.60 & \\
\hline Lysine $\mathrm{N}$ & 8.26 & 7.02 & 6.14 & 6.18 & \\
\hline Monoamino $\mathrm{N}$ & 54.32 & 48.76 & 49.76 & 48.28 & 58.74 \\
\hline Non-amino $N$ & & 7.12 & 8.56 & & \\
\hline
\end{tabular}

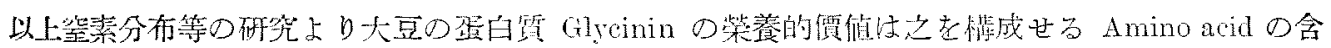

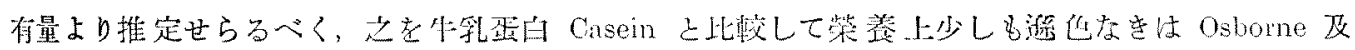

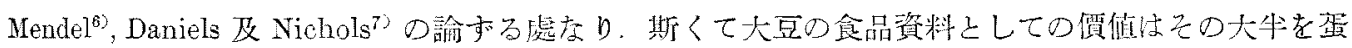

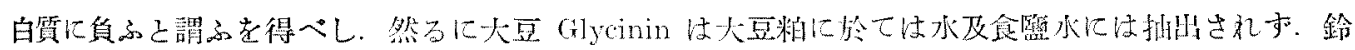

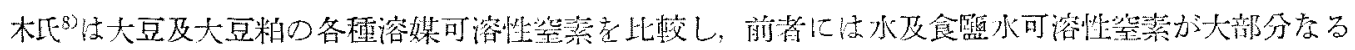

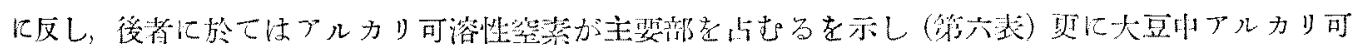

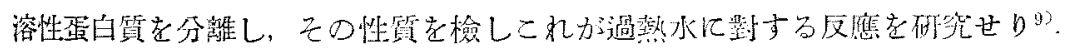

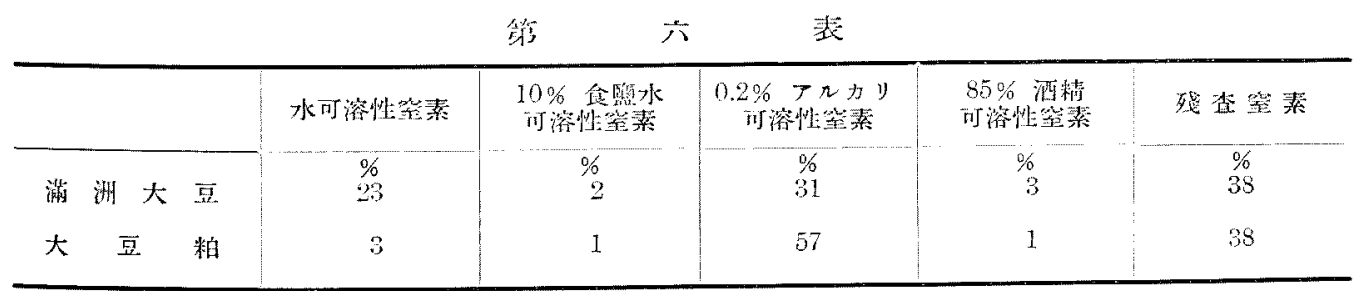

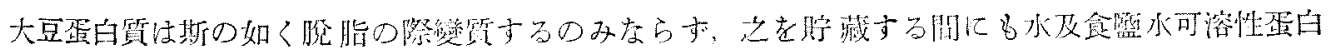

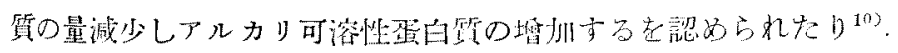

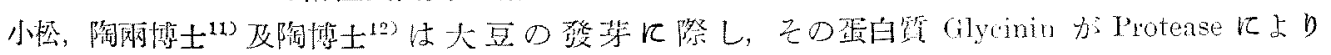

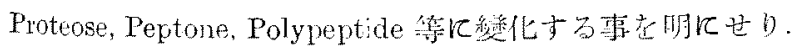

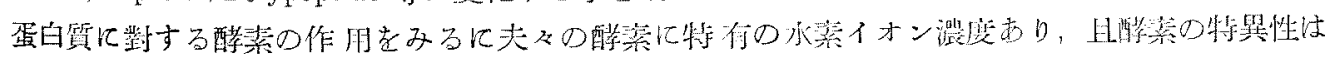

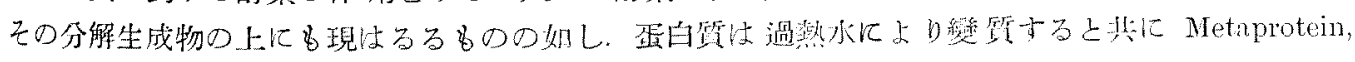

1) J. Biol. Chem., $20(1915), 611.2$ 2) J. Am. Chem. Soc., $37(1915), 276:$. $(1923), 810 . \quad 4) \quad$ J. Biol. Chem., $51(1922), 17$. 80 (1912), 30б; J. Biol. Chem., $32(1917), 369$. 5) 大邽工, $7(1926)$, 第, 9 喝.

3) J.Am. Chem. Soc., 45 7) J. Biol.Chem, 32 (1917), 91 8) 本誌, 51 (1930), 729.

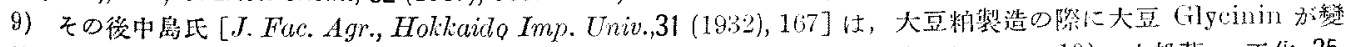

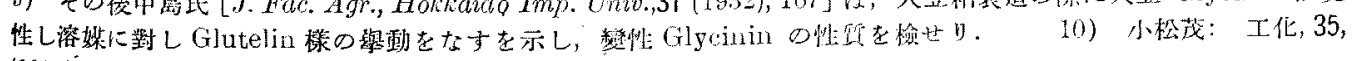
(1932), 397 .

11) 索理紀, A, 14(1931), 287.

12) 同上, 293. 


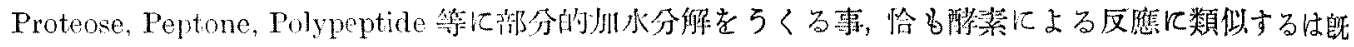
に明にせられたり

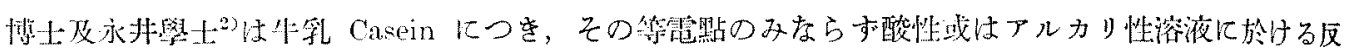

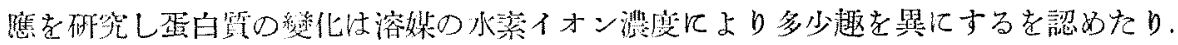

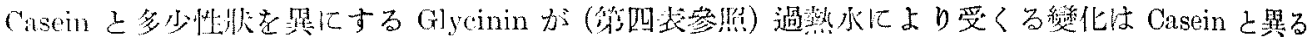

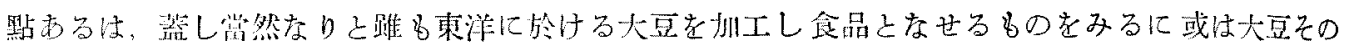

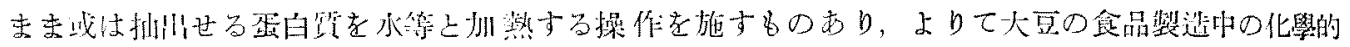

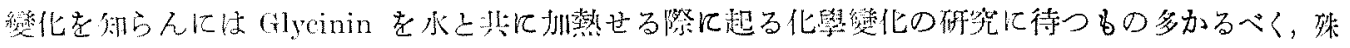

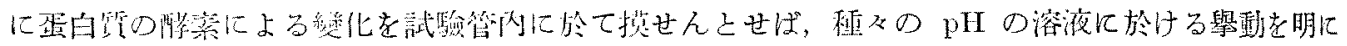
ナるにありこ存へたり。

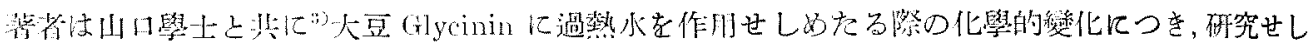

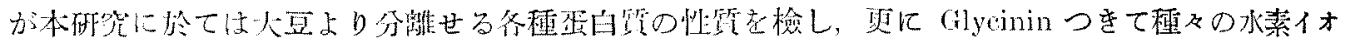

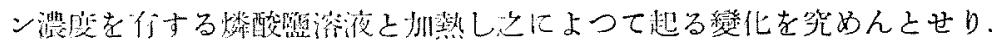

\section{I. 大 豆 蛋 白 質}

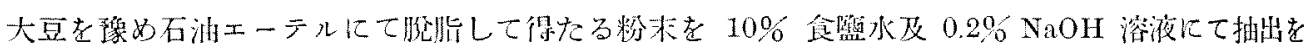

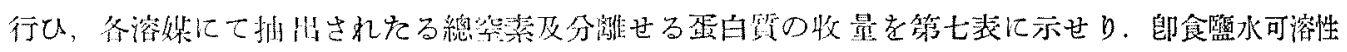

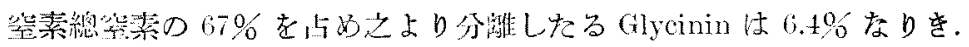

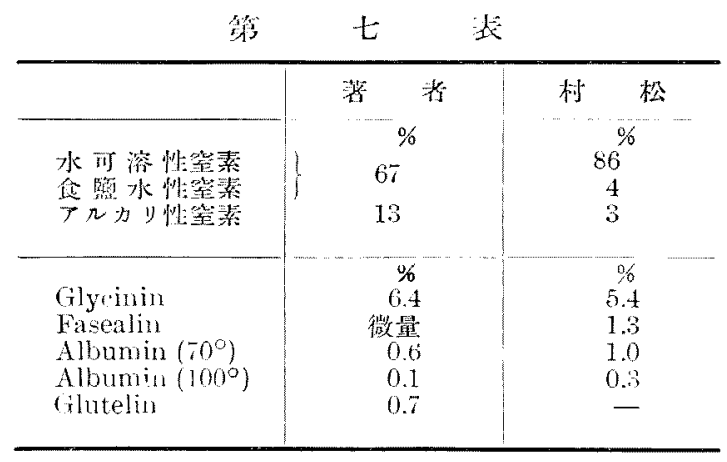

\begin{tabular}{|c|c|c|}
\hline & 諾 诰 & $\begin{array}{l}\text { Osborne \& } \\
\text { Campbell }\end{array}$ \\
\hline C & 52.75 & $52 \%$ \\
\hline $\mathrm{H}$ & 7.56 & 6.93 \\
\hline $\mathrm{N}$ & 17.08 & 17.53 \\
\hline $\mathrm{S}$ & 0.73 & 0.79 \\
\hline 灰 分 & 0.55 & - \\
\hline
\end{tabular}

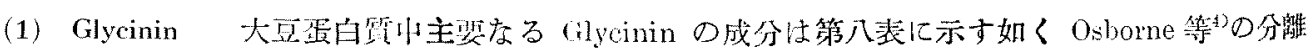
せるるのと一致せり。

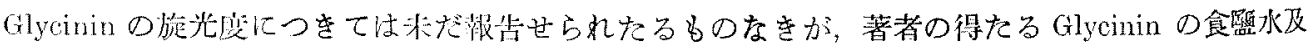

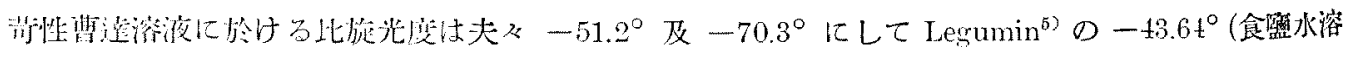
液) 及 Plinseolin ${ }^{5}$ の $-41.46^{\circ}$ (同) に比して高委值を示せり。

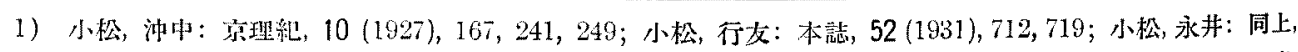
691 ; 小松, 林: 同上, 463 ; 小松, 木下: 同上, 696 ; 小松, 古武: 同上, 703 ; 鈴木, 同上, 51 (1930), 729.2 2) 前出.

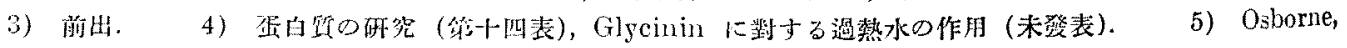
Harries: J. Am. Chem. Soc., 25 (1903), 842. 
第九 表 Glycinin 比旋光度

\begin{tabular}{l|c}
\hline$\alpha]_{\mathrm{D}} 10 \% \mathrm{NaCl}$ 溶液 & $-51.2^{\circ}$ \\
{$[\alpha]_{\mathrm{D}}{ }_{1}^{1} \mathrm{~N} \mathrm{NaOH}$ 溶液 } & $-70.3^{\circ}$ \\
\hline
\end{tabular}

第十表 Glycinin 䂏装分布

\begin{tabular}{|c|c|c|}
\hline & 著者 & $\begin{array}{c}\text { Osborne \& } \\
\text { Harries }\end{array}$ \\
\hline Amide $N$ & $\begin{array}{r}\% \\
13.69\end{array}$ & $\begin{array}{r}\% \\
12.06\end{array}$ \\
\hline Humin $N$ & 0.75 & 0.69 \\
\hline Diamino $N$ & 22.08 & 22.57 \\
\hline Monoamino $\mathrm{X}$ & 62.64 & 64.7 \\
\hline
\end{tabular}

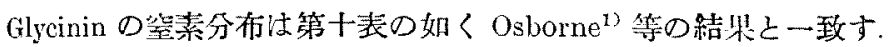

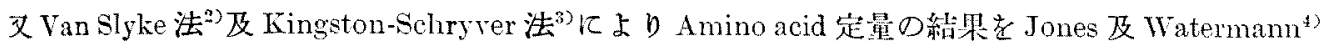
の結果と比較するに第十一表に示す如し.

第十 - 裴 Glycinin 分析

\begin{tabular}{|c|c|c|c|c|}
\hline \multirow[b]{2}{*}{ 分 } & \multirow[b]{2}{*}{ 析 } & \multicolumn{2}{|l|}{ 著 } & \multirow{2}{*}{$\frac{\text { Jones \& Waterman }}{\text { Van Slyke 法 }}$} \\
\hline & & Van Slyke 法 & Kingston \& Schryver 法 & \\
\hline \multicolumn{2}{|c|}{ Amide $\mathrm{N}$} & $\begin{array}{r}\% \\
11.9\end{array}$ & $\%$ & $\begin{array}{r}\% \\
12.91\end{array}$ \\
\hline \multicolumn{2}{|c|}{ Humin $\mathrm{N}$} & 1.7 & 0.7 & 2.97 \\
\hline \multicolumn{2}{|c|}{ Diamino $\mathrm{N}$} & 24.0 & 24.3 & 28.00 \\
\hline \multicolumn{2}{|c|}{ Arginine $\mathrm{N}$} & 13.9 & 12.6 & 15.35 \\
\hline \multicolumn{2}{|c|}{ Histidine $\mathrm{N}$} & 0.8 & 2.6 & 2.38 \\
\hline \multicolumn{2}{|c|}{ Lysine N } & 9.3 & 8.3 & 10.27 \\
\hline \multicolumn{2}{|c|}{ Dicarboxylic acid $N$} & - & 13.2 & - \\
\hline \multicolumn{2}{|c|}{ Tyrosine N } & - & 1.5 & - \\
\hline \multicolumn{2}{|c|}{ Monoamino $\mathrm{N}$} & 62.1 & $48.1^{*}$ & 58.12 \\
\hline
\end{tabular}

* Dicarboxylic acid $\mathrm{N}$ 及 Tyrosine $\mathrm{N}$ 老除く.

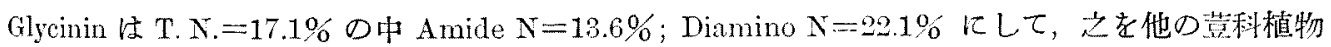
種子の Globulin と比較すれば第十二表に示す如く T. X. に於て Legumin より少く, Vicilin, Vignin

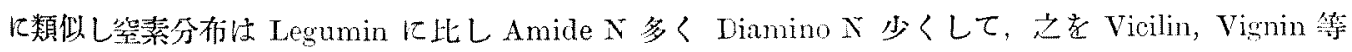
に比するす Diaminoエ少きがその差は主しして Arginine による党知るべし。

$$
\text { 第十二表市 }
$$

\begin{tabular}{|c|c|c|c|c|c|c|}
\hline & T. X. & Amide $\mathrm{N}$ & Diamino $\mathrm{N}$ & Histidine & Arginine & Lysine \\
\hline Glycinin & 17.45 & $\begin{array}{r}\% \\
12.1\end{array}$ & $\begin{array}{r}\% \\
22.6\end{array}$ & $\begin{array}{r}\% \\
2.10\end{array}$ & $\begin{array}{r}\% \\
7.69\end{array}$ & $\begin{array}{r}\% \\
3.59\end{array}$ \\
\hline Legumin & 1804 & 9.3 & 28.3 & 1.69 & 11.73 & 4.98 \\
\hline Vicilin & 17.05 & 10.0 & 28.8 & 2.17 & 8.91 & 5.40 \\
\hline Vignin & 17.55 & 11.1 & 24.8 & 3.08 & 7.20 & 4.31 \\
\hline Phaseolin & 16.20 & 10.4 & 22.5 & 2.62 & 4.87 & 4.58 \\
\hline
\end{tabular}

1) 前出. 2) Abderhalden: 'Handb. d. biol. Arbeitsmethoden, abt. I, T1. 7, S. 53

3) Biochem.
$J ., 18(1924), 1070$.
4) 前出.
5) Osborne: The Vegetable Proteins' (1924), 72. 
(2) Albumin 村松博士は1) Albumm はその水溶液より凝固する溫度により二種に分れ, $70^{\circ}$ に て凝固するものは Osborne 等の分雖せる Legumelin に一致するも，100\%て凝固するものは新 Albumin なりとし之衣 Soylegumelin と命名せり。畒者の得をる二種の Albumin はその凝固溫度を

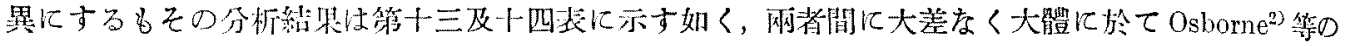
成䋩と一政せり。

$$
\text { 渻十三表 Albumin }
$$

\begin{tabular}{|c|c|c|c|c|c|}
\hline & 䕰 & 者 & 村 & 松 & Osborne \\
\hline & $70^{\circ}$ 凝图 & $100^{\circ}$ 淡因圆 & Legumelin & Soylegumelin & Legumelin \\
\hline $\mathrm{C}$ & $\begin{array}{r}\% \\
53.67\end{array}$ & $\begin{array}{r}\% \\
53.30\end{array}$ & 53.15 & $\begin{array}{r}\% \\
52.98\end{array}$ & $\begin{array}{r}\% \\
53.06\end{array}$ \\
\hline$H$ & 7.14 & 6.99 & 6.73 & 6.79 & 6.94 \\
\hline $\mathrm{N}$ & 15.74 & 15.60 & 16.27 & 15.14 & 16.14 \\
\hline
\end{tabular}

第十四表 Albumin 紫㨞分布

\begin{tabular}{|c|c|c|c|c|}
\hline & \multicolumn{2}{|l|}{ 畄 } & \multicolumn{2}{|c|}{ Osborne \& Harries } \\
\hline & $70^{\circ}$ 凝目 & $100^{\circ}$ 凝域 & I.egumelin & $\begin{array}{c}\text { 太豆 } \\
\text { Albumin }\end{array}$ \\
\hline Amide $N$ & $8 \%$ & 8.7 & $\begin{array}{l}\% \\
6.4\end{array}$ & $\begin{array}{r}\% \\
7.3\end{array}$ \\
\hline Humin N & 4.1 & 7.3 & 2.3 & - \\
\hline Diamiso $N$ & 20.4 & 19.7 & 24.1 & 19.1 \\
\hline Monoamino X & 66.3 & 68.0 & 67.1 & 71.1 \\
\hline
\end{tabular}

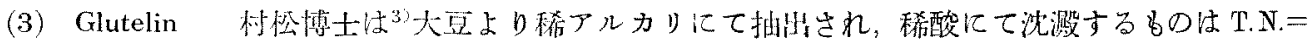

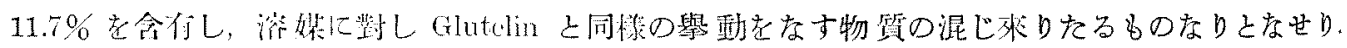
者者の得たる Glutelinの分析䋨果は符十五表に示高如く，一般蛋白筫の平均組成 $\mathrm{C}=51 \sim 53 \%, \mathrm{H}=$

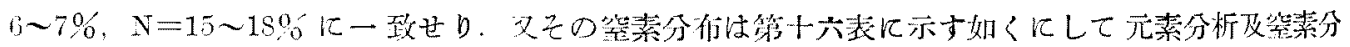

第十五斐 Glutelin

\begin{tabular}{|c|c|c|}
\hline & 智眚 & 䍅 水 \\
\hline $\mathrm{O}$ & $\begin{array}{r}\% \\
53.45\end{array}$ & $\begin{array}{r}\% \\
53.40\end{array}$ \\
\hline $\mathrm{H}$ & 7.10 & 6.91 \\
\hline 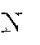 & 15.12 & 15.8 \\
\hline
\end{tabular}

符十六表 Glutelin 紫素分布

\begin{tabular}{|c|c|c|}
\hline & 著 倠 & 鈴 木 \\
\hline Amide $N$ & 9.7 & 9.7 \\
\hline Humin $\mathrm{N}$ & 3.9 & 1.9 \\
\hline Diamino $\mathrm{N}$ & 23.7 & 18.7 \\
\hline Monoamino $\mathrm{N}$ & 62.8 & 698 \\
\hline
\end{tabular}

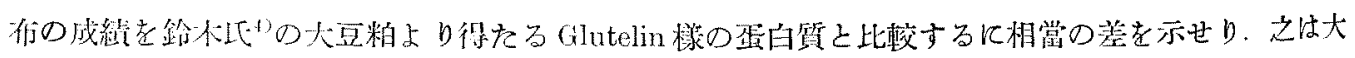
豆蛋白に於てはGlycinin の變化したるるのを合むためなり。
1) 前出.
2) 前出.
3) 前出.
4) 前出. 


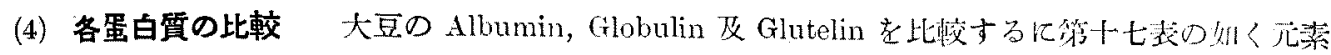

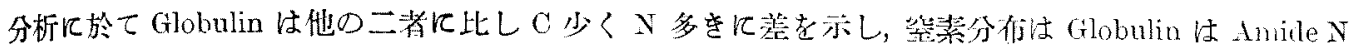
最子多くDiamino N は他蛋白の中間を占む。

\begin{tabular}{|c|c|c|c|c|}
\hline & Albumin & Globulin & Glutelin & 大豆粗策白 \\
\hline $\mathrm{C}$ & $\begin{array}{r}\% \\
53.5\end{array}$ & $\begin{array}{r}\% \\
52.8\end{array}$ & $\begin{array}{r}\% \% \\
53.4\end{array}$ & $\begin{array}{r}\% \\
53.4\end{array}$ \\
\hline $\mathrm{H}$ & 7.0 & 7.6 & 7.1 & 6.9 \\
\hline $\mathrm{N}$ & 15.7 & 17.7 & 10.1 & 15.8 \\
\hline Amide $\mathrm{N}$ & $\begin{array}{l}\% \\
8.6\end{array}$ & $\begin{array}{r}\% \\
13.7\end{array}$ & $\%$ & $\begin{array}{r}\% \\
9.7\end{array}$ \\
\hline Diamiuo $\mathrm{X}$ & 20.4 & 22.1 & 23.7 & 18.7 \\
\hline Monoamino $\mathrm{I}$ & $66 . .3$ & 62.6 & 62.8 & 69.8 \\
\hline $\begin{array}{c}\text { Uonoamino }{ }^{2} \text { : } \\
\text { Diamino } \mathrm{X}\end{array}$ & 3.3 & 2.9 & 2.6 & 3.7 \\
\hline
\end{tabular}

1) 鈴木 (前出).

ての䒕素分析站に空素分布より Globulin が變質し，その性快 Glutelin 栐のものとなりたる時之を

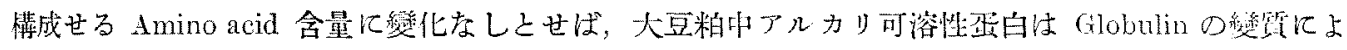

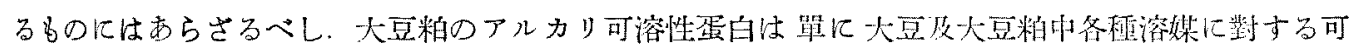

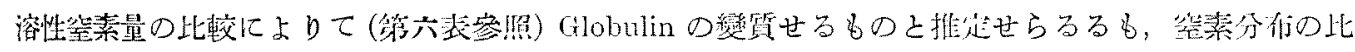

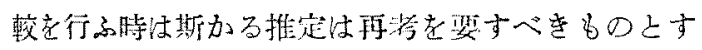

\section{Glycinin に對する過熱水の作用}

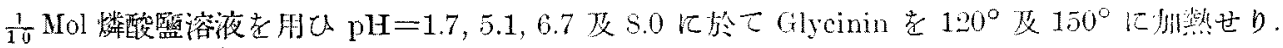

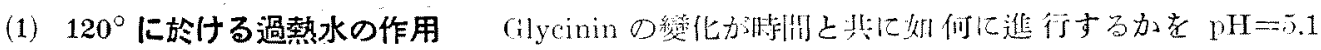

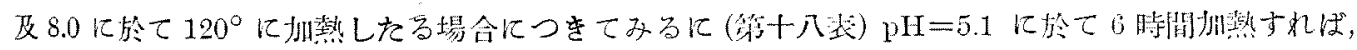

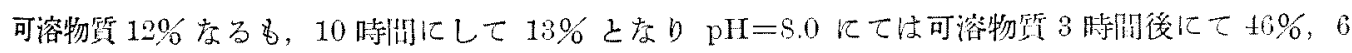

$$
\text { 第十八表 Glycinin }\left(120^{\circ}\right)
$$

\begin{tabular}{|c|c|c|c|c|c|c|}
\hline $\mathrm{pH}$ & & 5.1 & & & 8.0 & \\
\hline 時 閏 & 6 & 10 & 20 & 3 & 6 & 10 \\
\hline pH（反應後） & 5.5 & 5.6 & 5.6 & 7.1 & 7.0 & 6.9 \\
\hline $\begin{array}{l}\text { 可溶物留 } \\
\text { 可溶性空蒵 }\end{array}$ & $12 \%$ & $\begin{array}{l}13 \% \\
12\end{array}$ & $\begin{array}{l}19 \% \\
18\end{array}$ & $\begin{array}{l}46 \% \\
46\end{array}$ & $77 \%$ & $7 \%$ \\
\hline 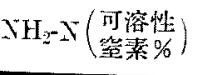 & 4.2 & 5.3 & 60 & 3.8 & 4.4 & 2.7 \\
\hline
\end{tabular}

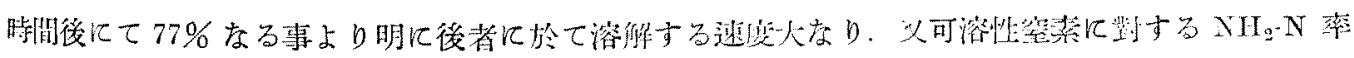

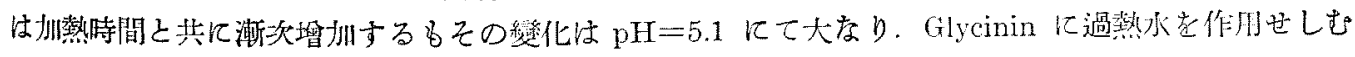

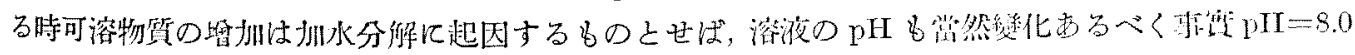
の場合には反應後 $\mathrm{pH}=7$ に, $\mathrm{pH}=5.1$ の場合には $\mathrm{pH}=5.6$ に移動与る事老䫏察せり。 
次に反應洔间 6 時間の場合につを，溶液の $\mathrm{pH}$ 己可溶物質との關係をみるに (第十九表, 第 1 圖)

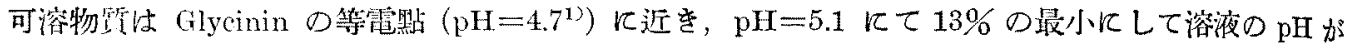
第十九 裉 Glycinin $\left(120^{\circ}, 6\right.$ 時間)

\begin{tabular}{|c|c|c|c|c|c|}
\hline $\mathrm{pH}$ (反䍐前) & 1.7 & 3.7 & 5.1 & 6.7 & 8.0 \\
\hline $\mathrm{pH}$ (反脽後) & 3.2 & 4.4 & 5.6 & 6.7 & 7.0 \\
\hline 可㴦物留 & $75 \%$ & $12 \%$ & $12 \%$ & $52 \%$ & $77 \%$ \\
\hline 不溶物質 & 23 & 90 & 87 & 43 & - \\
\hline
\end{tabular}

第 1 區

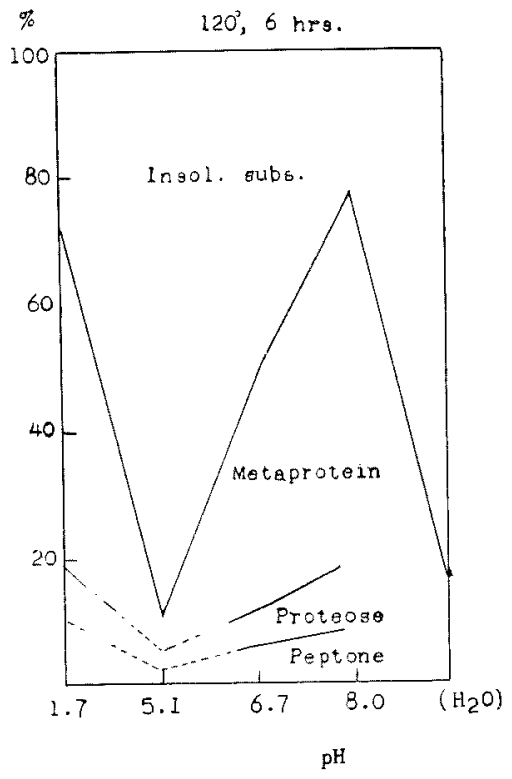

第 2 圆

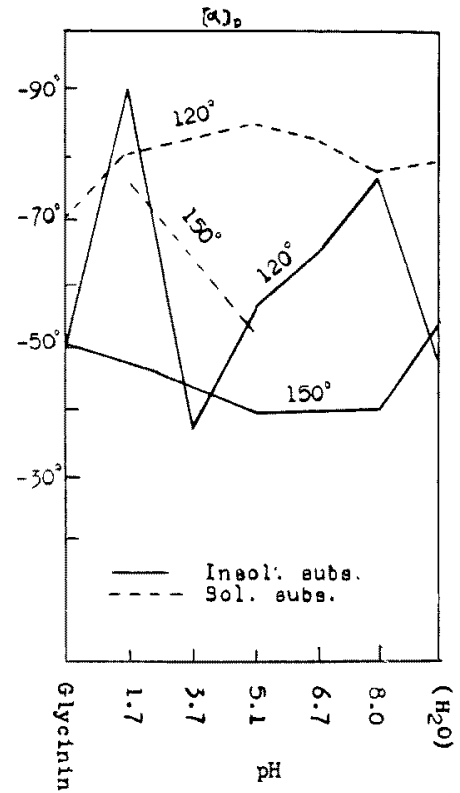

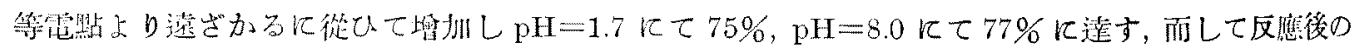
溶液の $\mathrm{pH}=6.7$ の場合には螨化なく，之上り酸性の溶液にて反應せしめし場合にはアルカリ性の方

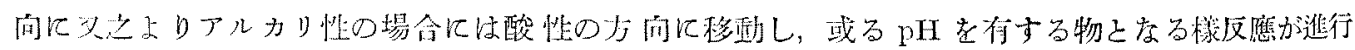

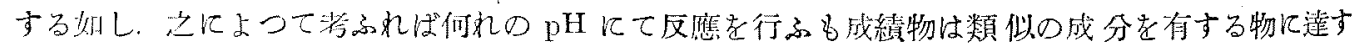
る力测し.

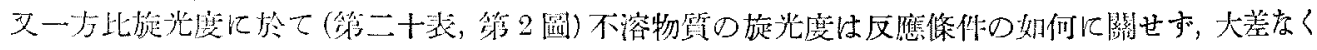

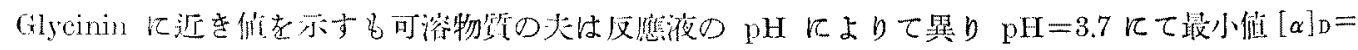
$-36^{\circ}$ Kして $\mathrm{pH}$ 己より大或は小となるによつて, 大となり $\mathrm{pH}=1.7$ にて $[\alpha]_{\mathrm{D}}=-91^{\circ}, \mathrm{pH}=8$ に

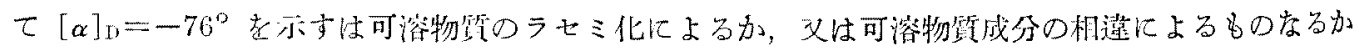
更に研究安慗寺。

1) Csonka, Murply, Jones: J. Am. Chem. Soc., 51 (1926), 763. 


\begin{tabular}{|c|c|c|c|c|c|c|}
\hline $\mathrm{pH}$ & Glycinin & 1.7 & 3.7 & 5.1 & 6.7 & 8.0 \\
\hline 可 溶物 貿 & $-51^{\circ}$ & $-91^{\circ}$ & $-36^{\circ}$ & $-56^{\circ}$ & $-63^{\circ}$ & $-i 6^{\circ}$ \\
\hline $\begin{array}{l}\text { 不 溶 物 留 } \\
\left(\frac{\mathrm{N}}{10} \mathrm{NaOH} \text { 溶腹 }\right)\end{array}$ & $-70^{\circ}$ & $-80^{\circ}$ & - & $-84^{\circ}$ & $-82^{\circ}$ & $-77^{\circ}$ \\
\hline
\end{tabular}

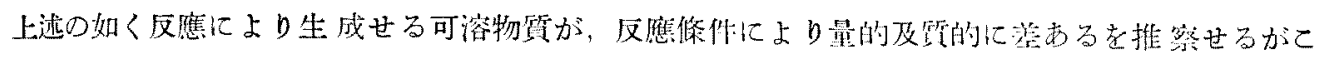

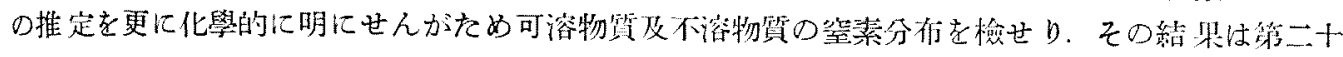

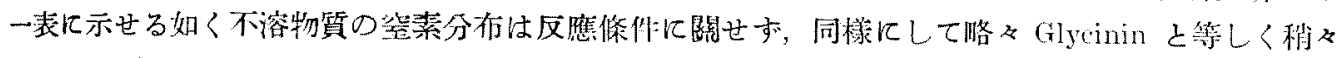

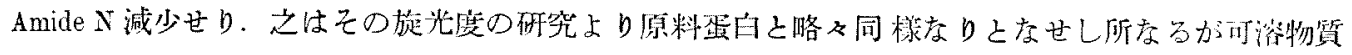
第二十一表 独素分们 $\left(120^{\circ}\right)$

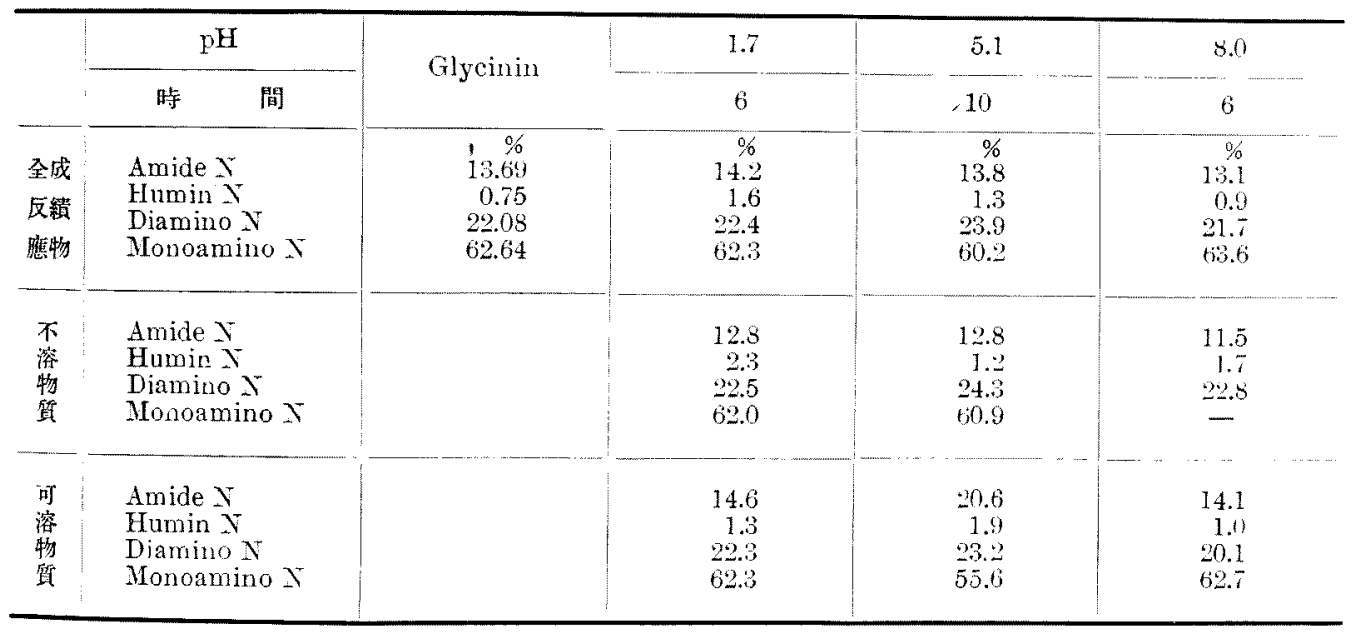

に於ては $\mathrm{pH}=5.1$ に於て他の場合に比し變化著しくAmide $\mathrm{x}$, Glycinin 上り約506增加L Mono-

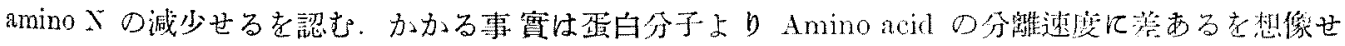
Lむるを以て次に Wasteneys 及 Borsook ${ }^{12}$ 亿從ひ, 可溶物筫中 Metaprotein, Proteose, Peptone 等の

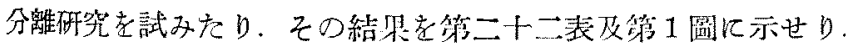

第二十二表 $\left(120^{\circ}, 6\right.$ 時䦌 $)$

\begin{tabular}{|c|c|c|c|c|}
\hline $\mathrm{pH}$ & 1.7 & 5.1 & 6.7 & 8.0 \\
\hline 可㴧性 空 素 & $71 \%$ & $13 \%$ & $45 \%$ & $78 \%$ \\
\hline Metaprotein $\mathrm{X}$ & 75 & 46 & 78 & 76 \\
\hline Proteose N & 11 & 28 & 11 & 14 \\
\hline Peptone 及 Subpeptone-N & 14 & 27 & 11 & 10 \\
\hline $\mathrm{NH}_{2} \cdot \mathrm{N}$ & 4.1 & 5.3 & 2.1 & 4.4 \\
\hline
\end{tabular}

1) J. Biol. Chem., 62 (1923), 1. 
即ち $\mathrm{pH}=1.7$ 及 8.0 に於て窒素率上り算定せる Metaprotein, Proteose, Peptone 等の量略々等し く, 然も Metaprotein ての75\%を占むるも $\mathrm{pH}=5.1$ に於ては獨り他の場合と異り Proteose 及夫以

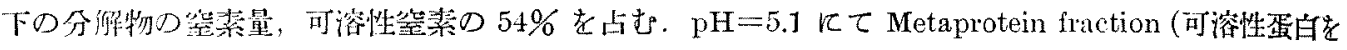

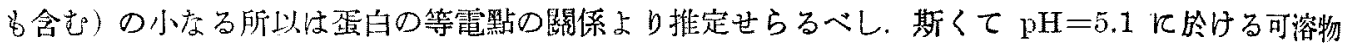

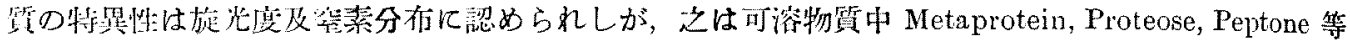
の比率の双にるるのなるか，或は义之等分解物の性質が他の場合の夫等上相湋あるものなるかを

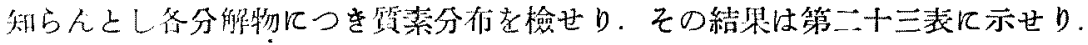

Metaprotein： $\mathrm{pH}$ の如何により跮筫分仍に差なく平均A mide $\mathrm{N}=12 \%$; Diamino $\mathrm{N}=21 \%$; Monoamino $N$ : Diamino $N=3.0 k し て$ Glycinin $の$ 倠に近し.

第二十三表 等芬们 $\left(120^{\circ}\right)$

\begin{tabular}{|c|c|c|c|c|c|}
\hline \multicolumn{2}{|r|}{$\mathrm{pH}$} & \multirow{2}{*}{ Glycinin } & 1.7 & 5.1 & 8.0 \\
\hline \multirow[b]{2}{*}{ 经 } & 呩 & & 6 & 10 & 6 \\
\hline & Amide $x$ & $\begin{array}{r}\% \\
13.69\end{array}$ & $\begin{array}{r}\% \\
12.8\end{array}$ & $\begin{array}{r}\% \\
12.8\end{array}$ & $\begin{array}{r}\% \\
11.5\end{array}$ \\
\hline \multirow{3}{*}{$\begin{array}{l}\text { 㳵 } \\
\text { 炽 }\end{array}$} & Humin $X$ & 0.75 & 2.3 & 1.2 & 1.7 \\
\hline & Diamino $\mathrm{N}$ & 22.08 & 22.5 & 24.3 & 22.8 \\
\hline & Monoamino N & 62.64 & 62.0 & 60.9 & - \\
\hline$k$ & $\begin{array}{l}\text { Monoamuno N: } \\
\text { Diamino }\end{array}$ & 2.9 & 2.8 & 2.5 & 2.9 \\
\hline \multirow{5}{*}{ 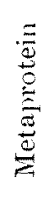 } & Anide $X$ & & 12.3 & 11.1 & 11.2 \\
\hline & Humin $N$ & & 2.4 & 5.2 & 2.0 \\
\hline & Damino $X$ & & 21.6 & 20.0 & 21.8 \\
\hline & Monoamino $\mathrm{y}$. & & 62.5 & 61.0 & 65.9 \\
\hline & $\begin{array}{c}\text { Monoamulu } \mathrm{A} \\
\text { Diamino }\end{array}$ & & 2.9 & 3.0 & 3.0 \\
\hline \multirow{5}{*}{$\begin{array}{l}0 \\
0 \\
0 \\
0 \\
0 \\
0\end{array}$} & Amide $\mathrm{X}$ & & 8.8 & 13.6 & 13.2 \\
\hline & Humin $x$ & & 0.8 & 3.9 & 0.9 \\
\hline & Diamino $\mathrm{N}$ & & 31.8 & 22.8 & 24.5 \\
\hline & Jonoamino $\mathrm{x}$. & & 57.4 & 61.3 & 58.7 \\
\hline & $\begin{array}{c}\text { Monoanmo A: } \\
\text { Diamino X }\end{array}$ & & 1.8 & 2.7 & 2.5 \\
\hline \multirow{5}{*}{ 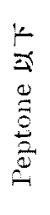 } & Amide $x$ & & 42.7 & 48.3 & 56.2 \\
\hline & Humin $X$ & & 1.2 & 0.8 & 0.8 \\
\hline & Tramino $\mathrm{X}$ & & 10.7 & 5.0 & 6.7 \\
\hline & Yonoamino $\mathrm{X}$ & & 43.1 & 46.4 & 34.1 \\
\hline & $\begin{array}{c}\text { Monoammo N: } \\
\text { Diamitio }\end{array}$ & & 4.0 & 9.3 & 5.1 \\
\hline
\end{tabular}

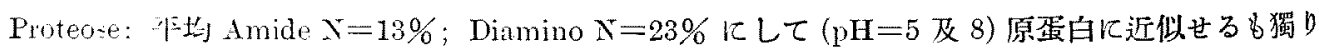
$\mathrm{pH}=1.7$ の場合に多少罢りたる成瞥を示し, Amide $\mathrm{N}=9 \%$ ； Diamino $\mathrm{N}=32 \%$; Monoamino $\mathrm{N}$ ： Diamino $N=1.8$ 店 $D$.

Peptone 以下: この Fraction は Polypeptide 等をも含むものにして, 原蛋白と著しく異りたる䇴

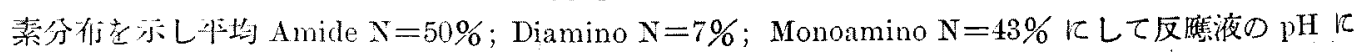

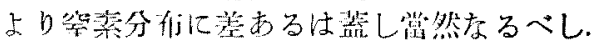


要するに Glycinin は過熱水により不溶物質と可溶物質走生成するが，反碓液の $\mathrm{pH}$ に關せす不溶

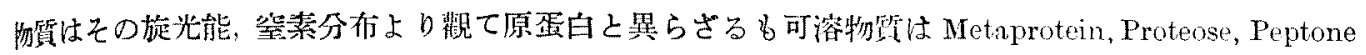
等の加水分解物よりなり $\mathrm{pH}=5$ に於ては Proteose 以下の分解物過牛を占め，他の場合には Metapro-

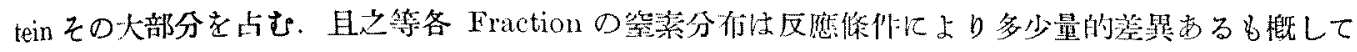

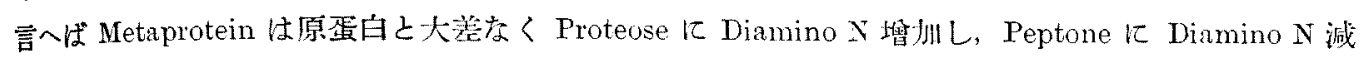

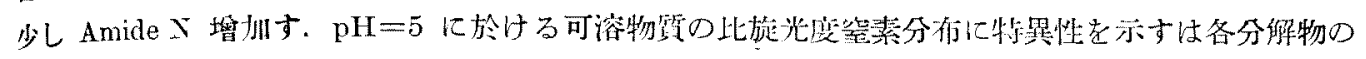
量的差買殊に Proteose 以下の下級分解物が比較的多を事に上り說明し得べし. 各分解生成物の成分

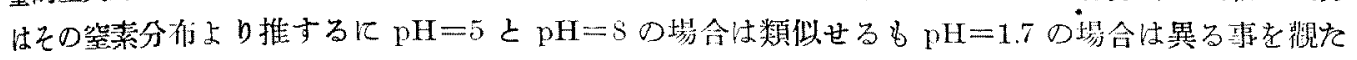
b.

\section{(2) $120^{\circ}$ と $150^{\circ}$ に於ける過熱水の比較}

夯に前記 $120^{\circ}$ に於けると同等の條件にて $150^{\circ}$ に於て 3 時間反應せしめをる結果を前者と比较せ んとす.

まつ $\mathrm{pH}=5.1$ の場合につきてみるに $150^{\circ}$ の場合に於ては $120^{\circ}$ の場合に比し，當然反應速度を傮

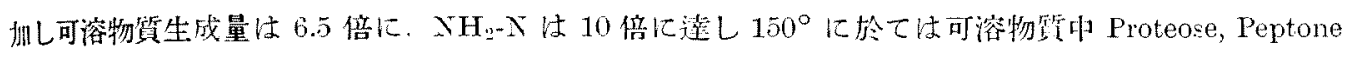
等の多を結果を示せり(第二十四及二十五装).

第二十四表 $\quad(\mathrm{pH}=5.1)$

\begin{tabular}{|c|c|c|}
\hline 反應條 件 & $120^{\circ}, 10$ 洔間 & $150^{\circ}, 3$ 洔消] \\
\hline $\mathrm{pH}$ (反應後) & 5.6 & 5.6 \\
\hline 可溶物 留 & $13 \%$ & $85 \%$ \\
\hline 不容物犋 & $s \bar{r}$ & 11 \\
\hline
\end{tabular}

第二十五. 表 $\quad(\mathrm{pH}=5.1)$

\begin{tabular}{|c|c|c|}
\hline 灰 鷹 低 件 & $1 \pm 0^{\circ}, 10$ 㭙洞 & $150^{\circ}, 3$ 㭙間 \\
\hline Soluble $\mathrm{N}$ & $12 \%$ & $83 \%$ \\
\hline $\begin{array}{l}\text { Metaprotein } \mathrm{N} \\
\text { Proteose } \mathrm{N} \\
\text { Peptone } \mathrm{N}\end{array}$ & $\begin{array}{l}42 \\
25 \\
33\end{array}$ & $\begin{array}{l}30 \\
31 \\
39\end{array}$ \\
\hline 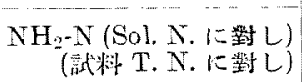 & $\begin{array}{l}5.3 \\
0.6\end{array}$ & $\begin{array}{l}7.7 \\
6.4\end{array}$ \\
\hline
\end{tabular}

\section{第二十六表}

䠛案分们 $(\mathrm{pH}=5.1)$

\begin{tabular}{|c|c|c|c|c|}
\hline & & Glyeinin & $1 \div 0^{\circ}, 10$ 時䦓 & $150^{\circ}, 3$ 時閒 \\
\hline 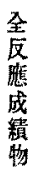 & $\begin{array}{l}\text { Amide } N \\
\text { Humin } N \\
\text { Diamino } N \\
\text { Monoamino } N\end{array}$ & $\begin{array}{l}13.69 \% \\
0.75 \\
22.08 \\
62.64\end{array}$ & $\begin{array}{l}13.8 \% \\
1.3 \\
23.9 \\
60.2\end{array}$ & $\begin{array}{l}15.5 \% \\
1.6 \\
22.5 \\
61.0\end{array}$ \\
\hline $\begin{array}{l}\text { 不 } \\
\text { 溶 } \\
\text { 物 } \\
\text { 筧 }\end{array}$ & $\begin{array}{l}\text { Amide } N \\
\text { Humin } N \\
\text { Diamino } N \\
\text { Monoamino } N\end{array}$ & & $\begin{array}{r}12.8 \\
1.2 \\
24.3 \\
60.9\end{array}$ & $\begin{array}{r}5.6 \\
3.2 \\
20.6 \\
68.5\end{array}$ \\
\hline $\begin{array}{l}\text { 可 } \\
\text { 洛 } \\
\text { 物 } \\
\text { 澌 }\end{array}$ & $\begin{array}{l}\text { Amide } N \\
\text { Humin } \mathrm{N} \\
\text { Diamino } N \\
\text { Monoamino } \mathrm{N}\end{array}$ & & $\begin{array}{r}20.8 \\
1.9 \\
23.2 \\
55.6\end{array}$ & $\begin{array}{r}17.3 \\
1.3 \\
22.6 \\
59.3\end{array}$ \\
\hline
\end{tabular}


次に反雇潈度の影響が反應速度のみならず, 反應生成物の上にも認めらるへしと考へ反應生成物 の䇪素分布考檢せり (第二十六及二十七表)，先づ反應生成物全體としての穻素分布をみるに $150^{\circ} に$ ては Amide $\mathrm{N}=15.5 \%$; Diamino $\mathrm{N}=23 \%$ にして Glycinin K比して Amide $\mathrm{N}$ 約 $2 \%$ の彁加を示せ り.之は $120^{\circ}$ に於ては認めさりし所なり.かかる變化は又獨り Glycininのみなら机既に Edestin Fibroin2 等に於ても認められたる所なり.

次に不溶物澌の空素分有についてみるに $150^{\circ}$ に於ける不溶物質は Amide $\mathrm{N}=6 \%$; Diamino $\mathrm{N}=$ 20\%； Monoamino N=69\%; Monoamino N : Diamino $N=3.3$ にして Amide N の減少著しく Monoamino N に則して Diamino N 減少し， $120^{\circ}$ の場合の不溶物筫が喵々原蛋白と近似せる窒素分布を

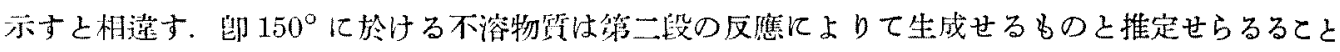
は更に徭章に論ずぺ。.

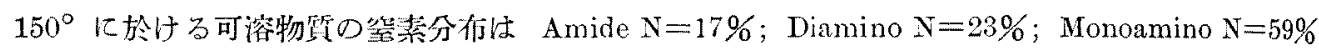

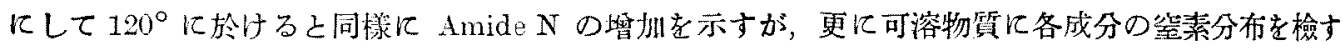

$$
\text { 第二十七表 空蓄分布 }(\mathrm{pH}=5.1)
$$

\begin{tabular}{|c|c|c|c|c|}
\hline & & Glycinin & $120^{\circ}, 10$ 時間 & $150^{\circ}, 3$ 時間 \\
\hline 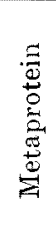 & $\begin{array}{l}\text { Amide } N \\
\text { Humin } \mathrm{N} \\
\text { Diamino } \mathrm{N} \\
\text { Monoamino } \mathrm{N} \\
\text { Monoamino N: Diamino } \mathrm{N}\end{array}$ & $\begin{array}{r}\% \\
13.7 \\
0.8 \\
22.1 \\
62.6 \\
2.9\end{array}$ & $\begin{array}{r}\% \\
11.1 \\
5.2 \\
20.0 \\
61.0 \\
3.0\end{array}$ & $\begin{array}{r}\% \\
6.9 \\
2.9 \\
23.4 \\
67.0 \\
2.9\end{array}$ \\
\hline 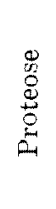 & $\begin{array}{l}\text { Amide } N \\
\text { Humin } N \\
\text { Diamino } N \\
\text { Monoamino N } \\
\text { Monoamino N: Diamino } N\end{array}$ & & $\begin{array}{r}13.6 \\
- \\
22.8 \\
61.3 \\
2.7\end{array}$ & $\begin{array}{r}8.4 \\
1.6 \\
24.4 \\
64.7 \\
2.6\end{array}$ \\
\hline$\frac{\mathfrak{\Xi}}{3}$ & $\begin{array}{l}\text { Amide } \mathrm{N} \\
\text { Humin } \mathrm{N} \\
\text { Diamino } \mathrm{N} \\
\text { Monoamino } \mathrm{N} \\
\text { Monoamino } \mathrm{N} \text { : Diamino } \mathrm{N}\end{array}$ & & $\begin{array}{r}48.3 \\
0.8 \\
5.0 \\
46.4 \\
9.3\end{array}$ & $\begin{array}{r}36.8 \\
1.1 \\
12.1 \\
48.7 \\
3.7\end{array}$ \\
\hline
\end{tabular}

るに(第二十七表) Metaprotein に於ては $120^{\circ}$ の場合に比し Amide N の減少著しき Monoamino

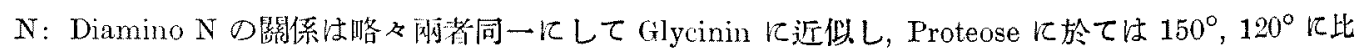

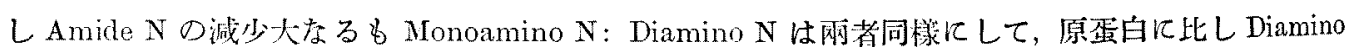
Nの增扠が認めらる. Peptone に於ては $120^{\circ}, 150^{\circ}$ いづれの場合も Amide N の增指 DiaminoNの 減少を示せり，勘ち $150^{\circ}$ に於ては $120^{\circ}$ の場合に比し AmideN の分解速なる b各 Fractionの Monoamino N: Diamino N の比は反應溫底の如何に關せ和同栐の仵を示すもの交り.

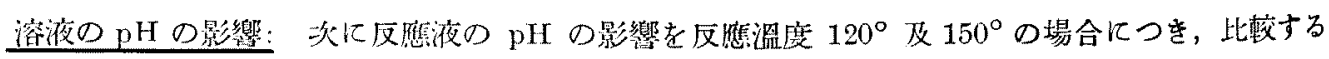

1) 小松, 沖中：前出. 2) 小松, 林: 前出. 


\section{第二十公表 $\left(150^{\circ}\right)$}

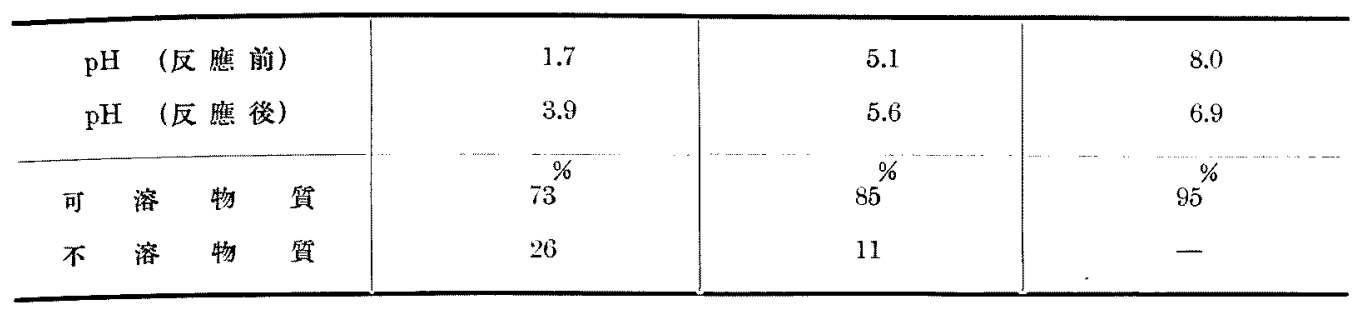

第二十九九素 $[\alpha]_{\mathrm{D}}\left(150^{\circ}, 3\right.$ 时間 $)$

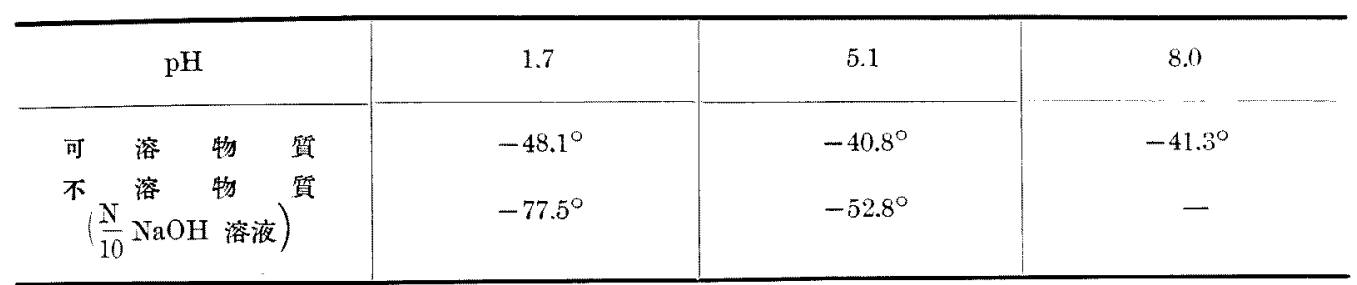

に $120^{\circ}$ にては蛋白質の溶解度は等電點に於て最小にして反應液 $\mathrm{pH}$ の之上り遠さかるに從ひ，大と古るも可溶物筫の加水分解度は逆に $\mathrm{pH}=5$ にて最大存る關係を示せしが， $150^{\circ}$ て於ては（第二十八表， 第 3 圆) 可溶物空生成量の反府液 $\mathrm{pH}$ 儿對する閣係は $120^{\circ}$ の場合之

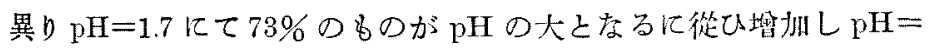
8.0 にて 95\% に逞し，反隹後溶液の $\mathrm{pH}$ は何れも $\mathrm{pH}=6$ に近づか んとする傾向を示きり。

比旋光庭 可溶物貿の旋光度は $120^{\circ}$ に於ける場合と異り $\mathrm{pH} の$ 如何几關せ和類似せる值を示し，不溶物質は反應保件により著しく 相違せる值を示す (第二十九表, 第 2 圖).

可溶性䇪素中 $\mathrm{NH}_{2}-\mathrm{N}$ は $\mathrm{pH}=1.7$ にて $14 \%$ の最大値を示し $\mathrm{pH}=$ $5.1 及 8.0$ にて $8 \%$ 或は $9 \%$ となり, 㨡水分解は溶解度と反對江 $\mathrm{pH}$ の小なる程大なるを示せるが可溶物質中各分据物の割合は企般老通 じ $120^{\circ}$ の場合に比し Proteose 以下が多く, 殊に Peptone 以下 35一 $55 \%$ 几達す、乙等下級分解物の生成量は $\mathrm{pH}=1.7$ にて坟大なり（第 三十表，第 3 圖)。

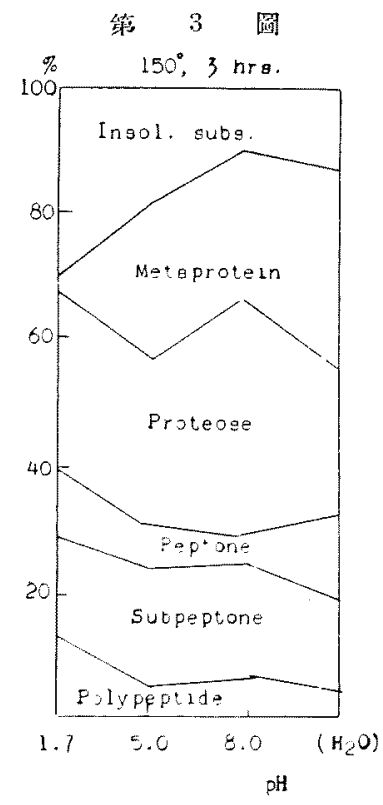




$$
\text { 第 三十表 }\left(150^{\circ}, 3 \text { 時間 }\right)
$$

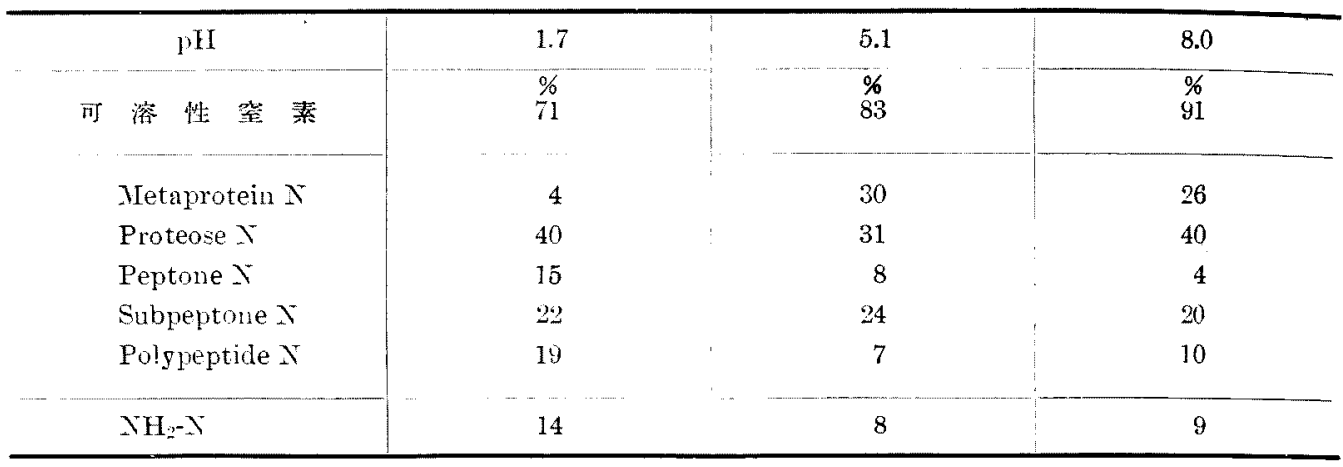

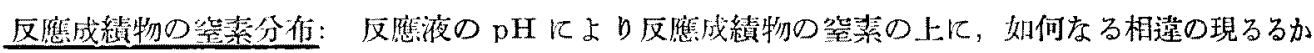

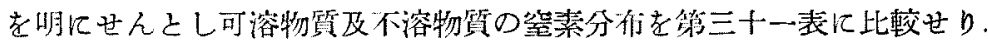

$$
\text { 第三十一表 空空窈分们 }\left(150^{\circ}, 3 \text { 時間 }\right)
$$

\begin{tabular}{|c|c|c|c|c|c|}
\hline & $\mathrm{pH}$ & Glycinin & 17 & 5.1 & 8.0 \\
\hline 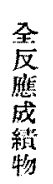 & $\begin{array}{l}\text { Amide } \mathrm{N} \\
\text { Humia } \mathrm{X} \\
\text { Diamino } \mathrm{N} \\
\text { Monoamino } \mathrm{X}\end{array}$ & $\begin{array}{r}\% \\
13.7 \\
08 \\
22.1 \\
62.6\end{array}$ & $\begin{array}{r}\% \\
16.4 \\
2.6 \\
20.5 \\
598\end{array}$ & $\begin{array}{r}\% \\
15.5 \\
1.6 \\
22.5 \\
61.0\end{array}$ & $\begin{array}{r}\% \\
17.3 \\
1.8 \\
20.5 \\
60.2\end{array}$ \\
\hline $\begin{array}{l}\text { 不 } \\
\text { 溶 } \\
\text { 物 } \\
\text { 貿 }\end{array}$ & $\begin{array}{l}\text { Amide } X \\
\text { Humin } X \\
\text { Diamino } X \\
\text { Monoamino } X\end{array}$ & & $\begin{array}{r}5.2 \\
5.8 \\
20.4 \\
68.7\end{array}$ & $\begin{array}{r}5.6 \\
3.2 \\
20.6 \\
68.5\end{array}$ & $\begin{array}{l}- \\
- \\
-\end{array}$ \\
\hline $\begin{array}{l}\text { 可 } \\
\text { 溶 } \\
\text { 物 } \\
\text { 县 }\end{array}$ & $\begin{array}{l}\text { Amide } X \\
\text { Humin } X \\
\text { Diamino } X \\
\text { Monoamino } X\end{array}$ & & $\begin{array}{r}20.7 \\
1.2 \\
20.7 \\
56.4\end{array}$ & $\begin{array}{r}17.3 \\
1.3 \\
22.6 \\
59.3\end{array}$ & $\begin{array}{r}17.1 \\
1.9 \\
20.3 \\
60.2\end{array}$ \\
\hline
\end{tabular}

全反應成績物つ学素分招はいづれの場合に於ても Glycinin より Amide $\mathrm{N}$ 增扣し, 之に相當し Diamino $\mathbf{X}$ 或は Monoamino $\mathrm{N}$ 減少せり。

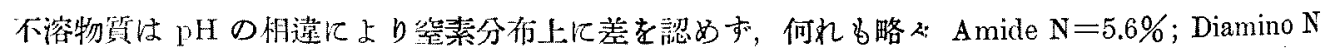
$=20 \%$; Monoanino $N=68 \%$ にして原蛋白に比し A mide N 減少し Monoamino N 增加せり.

可溶物質は原蛋白に比し Amide N (=17\%) の增州，Monoamino N (=60\%)の減少全般にみらる るも殊に $\mathrm{pH}=1.7$ にて著しく. Amide $\mathrm{N}=21 \%$ ； Diamino $\mathrm{N}=56 \%$ となる。

次江可溶物筫冬成分の空素分析を檢せし結果は第三十二表に示す如し. 


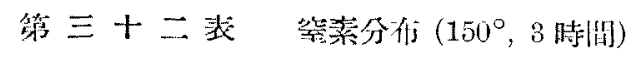

\begin{tabular}{|c|c|c|c|c|c|}
\hline & $\mathrm{pH}$ & Glycinin & 1.7 & 5.1 & 80 \\
\hline \multirow{5}{*}{ 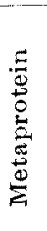 } & Amide $N$ & $\begin{array}{r}\% \\
13.7\end{array}$ & $\begin{array}{r}\% \\
7.0\end{array}$ & $\begin{array}{l}\% \\
6.3\end{array}$ & $\%$ \\
\hline & Humin $N$ & 0.8 & 4.6 & 2.9 & 3.3 \\
\hline & Diamino $\mathrm{N}$ & 22.1 & 19.9 & 23.4 & 22.4 \\
\hline & Nonoamino $\mathrm{X}$ & 62.6 & 67.6 & 67.0 & 66.2 \\
\hline & Nonoamino $\mathrm{N}$ : Diamino $\mathrm{N}$ & 2.9 & 3.4 & 2.9 & 3.0 \\
\hline \multirow{5}{*}{$\begin{array}{l}\stackrel{0}{0} \\
\stackrel{0}{0} \\
\stackrel{0}{0} \\
0\end{array}$} & Amide $\mathrm{N}$ & & 6.4 & 8.4 & 9.4 \\
\hline & Humin $x$ & & 1.5 & 1.6 & 1.5 \\
\hline & Diamino $\mathrm{N}$ & & 28.5 & 24.4 & 27.0 \\
\hline & Monoamino $x$ & & 63.5 & 64.7 & 65.5 \\
\hline & Monoamino $\mathrm{N}$ : Diamino $\mathrm{N}$ & & 2.2 & 2.6 & 2.5 \\
\hline \multirow{5}{*}{$\frac{\stackrel{0}{0}}{\stackrel{0}{0}}$} & Amide $\mathrm{N}$ & & 41.9 & 36.8 & 33.8 \\
\hline & Humin $\mathrm{X}$ & & 1.1 & 1.1 & 1.8 \\
\hline & Diamino $N$ & & 12.3 & 12.1 & 11.1 \\
\hline & Monoamino $\mathrm{N}$ & & 46.5 & 48.7 & 50.7 \\
\hline & Sonoamino $\mathrm{N}$ : Diamino $\mathrm{N}$ & & 3.7 & 4.0 & 4.6 \\
\hline
\end{tabular}

Metaprotein: $\quad \mathrm{pH}=1.7 \mathrm{k} \tau$ Amide $\mathrm{N}=7.0 \%$; Diamino $\mathrm{N}=20 \%$; Monoamino $\mathrm{N}$ : Diamino $\mathrm{N}=$ 3.4 Kして他の場合と異り Diamino $\mathrm{X}$ 少しく減少を示せるも $\mathrm{pH}=5$ 艾 $\mathrm{pH}=8$ にては略々等しく何

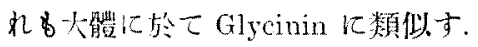

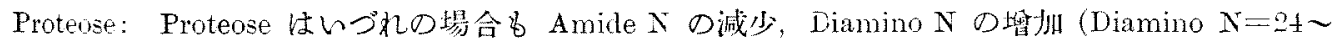
29\%; Monoamino X: Diamino N=2.5 2.2) 在示すbのなるが $\mathrm{pH}=1.7$ の場合他に比し如上の倾向 著し，この事注 $120^{\circ}$ の場合も同栐なり。

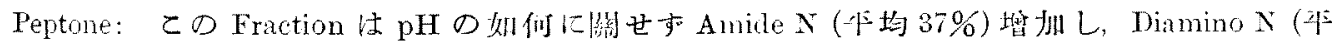
均 12\%: Monoamino $\mathrm{x}$ : Diamino $\mathrm{x}=3.7 \sim 4.6$ ) 減少するが $\mathrm{pH}$ によ差異は $\mathrm{pH}=1.7$ に於て認め らる.

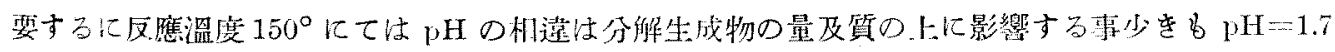

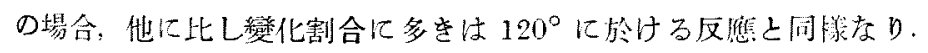

\section{(3) 燐酸鹽の影嵬}

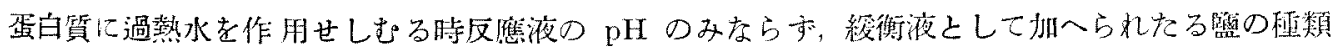

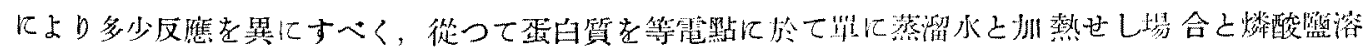

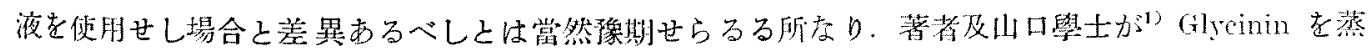

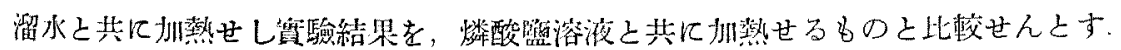

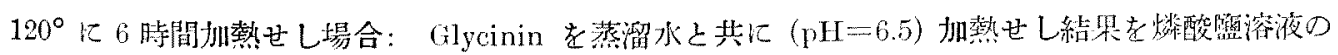

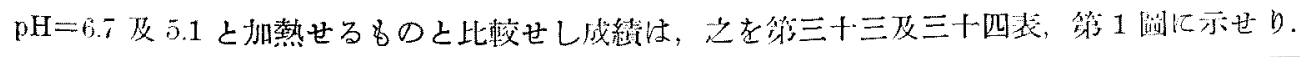

1) 前出. 
第三十三表 $\quad\left(120^{\circ}, 6\right.$ 時閏 $)$

\begin{tabular}{|c|c|c|c|c|c|c|c|c|}
\hline & & & & 燐 & 酸 & 㯺 & 溶 & 水 \\
\hline \multicolumn{4}{|c|}{$\mathrm{pH}$} & \multicolumn{2}{|l|}{5.1} & & 6.7 & 6.5 \\
\hline 耐 & 溶 & 物 & 筫 & $12^{\%}$ & & & $52^{\%}$ & $17^{\%}$ \\
\hline 不 & 溶 & 物 & 貿 & 88 & & & 43 & 83 \\
\hline $\mathrm{NH}_{2-}$ & (Sol & S. & L) & 4.2 & & & 2.1 & 6.3 \\
\hline & (試头 & $\therefore \mathrm{N}$ & 淑し) & 0.4 & & & 1.0 & 0.9 \\
\hline
\end{tabular}

第三十四表 $[\alpha]_{\mathrm{D}}\left(120^{\circ}, 6\right.$ 時闍 $)$

\begin{tabular}{|c|c|c|c|c|c|c|c|}
\hline & & & & 燐 & 樽 & 溶 & 水 \\
\hline \multicolumn{4}{|c|}{$\mathrm{pH}$} & 6.7 & & 5.1 & 6.5 \\
\hline 可 & 溶 & 物 & 質 & $-62.5^{\circ}$ & & $-56^{\circ}$ & $-48.1^{\circ}$ \\
\hline 不 & 溶 & 物 & 统 & $-82.4^{\circ}$ & & $-83.9^{\circ}$ & $-78.6^{\circ}$ \\
\hline
\end{tabular}

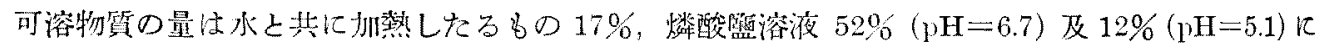

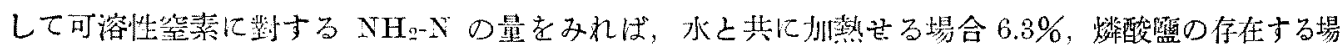
合 $2.1 \%(\mathrm{pH}=6.7)$ 及 $4.2 \%(\mathrm{pH}=5.1)$ にして水の場合は燐酸雨溶液 $\mathrm{pH}=6.7$ の場合に比し，可溶物

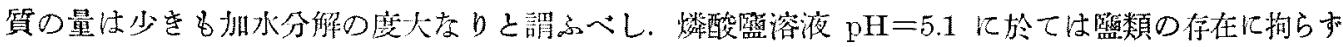
可塎物質の量, 水 $(\mathrm{pH}=6.5)$ の場合よりる小なるは Glycinin の等笔點 $(\mathrm{pH}=4.7)$ に近をによるへし.

不溶物質の比旋光度は三者略々等しを名可溶物質の夫は相常の差あり， $\mathrm{NH}_{2}-\mathrm{N}$ 率よりみて變化の 度大なる程小なる比旋光度を示せるは注慗すへし，

$150^{\circ}$ K3 洔间州熱せる場合：可溶物質の量は水已扎蓺せる時 $89 \%$ ，燐酸溶液已加熱せる時 $85 \%$

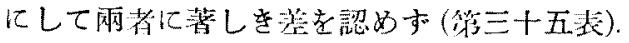

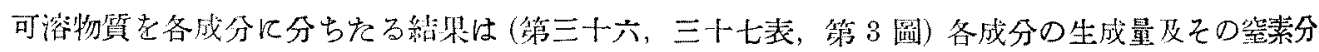

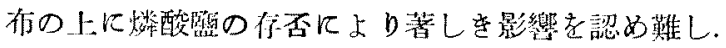

第三十五表 $\left(150^{\circ}, 3\right.$ 時間 $)$

\begin{tabular}{|c|c|c|}
\hline & 燐酸臨溶液 & 水 \\
\hline $\mathrm{pH}$ (反應前) & 5.1 & 6.5 \\
\hline pH (反胵㣞) & 5.6 & 6.5 \\
\hline 可溶物 啠 & $85 \%$ & $89 \%$ \\
\hline 不溶物 貿 & 11 & 8 \\
\hline
\end{tabular}

\begin{tabular}{|c|c|c|}
\hline & 燐酸繁溶液 & 水 \\
\hline $\mathrm{pH}$ & 5.1 & 6.5 \\
\hline Soluble $\mathrm{X}$ & $83^{\%}$ & $89^{\%}$ \\
\hline Metaprotein N & 30 & 36 \\
\hline Proteose $\mathrm{N}$ & 31 & 30 \\
\hline Peptone $\mathrm{N}$ & 8 & 13 \\
\hline Subpeptone N & 24 & 16 \\
\hline Polypeptide $\mathrm{N}$ & 7 & 5 \\
\hline
\end{tabular}


第三十七裴 然素分们 $\left(150^{\circ} ， 3\right.$ 㭙間 $)$

\begin{tabular}{|c|c|c|c|c|c|c|c|}
\hline & & 烧酸擥溶液 & 水 & & & 蝼酸菴溶液 & 水 \\
\hline & $p \mathrm{H}$ & 5.1 & 6.5 & & $\mathrm{pH}$ & 5.1 & 6.5 \\
\hline \multirow{4}{*}{ 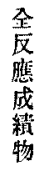 } & dmide $N$ & $15.5 \%$ & $15.7 \%$ & \multirow{4}{*}{ 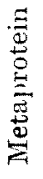 } & Amide $N$ & $6.3 \%$ & $7.0 \%$ \\
\hline & Humin $\mathrm{N}$ & 1.6 & 3.1 & & Humin $\mathrm{N}$ & 2.9 & 39 \\
\hline & Diamino $\mathrm{N}$ & 22.5 & 19.9 & & Diamino $\mathrm{N}$ & 23.4 & 22.5 \\
\hline & Monoamino $\mathrm{N}$ & 61.0 & 58.8 & & Monoamino $\mathrm{N}$ & 67.0 & 65.2 \\
\hline 不 & Amide $X$ & 5.6 & 5.6 & \multirow{4}{*}{ 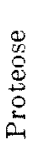 } & Amide $\mathrm{N}$ & 8.4 & 8.3 \\
\hline 溶 & Humin $\mathrm{X}$ & 3.2 & 6.1 & & Humin $\mathrm{N}$ & 1.6 & 1.7 \\
\hline 物 & Diamino $\mathrm{X}$ & $20 . \overline{5}$ & 19.9 & & Diamino $N$ & 24.4 & 24.7 \\
\hline 留 & Monoamino $\mathrm{X}$ & $68 . \overline{0}$ & 69.9 & & Monoamino $\mathrm{N}$ & 64.7 & 63.2 \\
\hline 可 & Amide X & 17.3 & 17.0 & \multirow{4}{*}{$\stackrel{\stackrel{g}{E}}{\stackrel{\Xi}{E}}$} & Amide $\mathrm{N}$ & 36.8 & 39.6 \\
\hline 爎 & Humin $\mathrm{Y}$ & 1.3 & 3.7 & & Humin N & 1.1 & 0.8 \\
\hline 物 & Diamino $Y$ & 22.6 & 19.9 & & Diamino $\mathrm{N}$ & 12.1 & 10.0 \\
\hline 筧 & Monoamino $\mathrm{X}$ & 59.3 & 57.4 & & Monoamino $\mathrm{N}$ & 48.7 & $\begin{array}{l}51.4 \\
57\end{array}$ \\
\hline
\end{tabular}

要するに燐酸盟の存否は反應溫度 $120^{\circ}$ に於て可浴物質生成量の上に，その影響老認むるる $150^{\circ}$

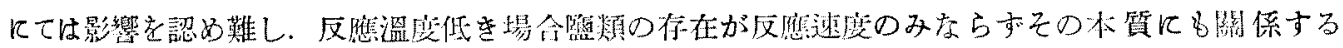
や否や唒研究を慗する處なり。

\section{（4）反應生成物の Amino acid}

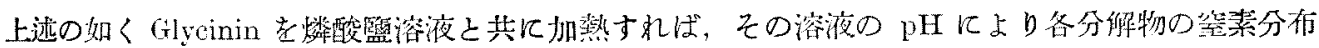

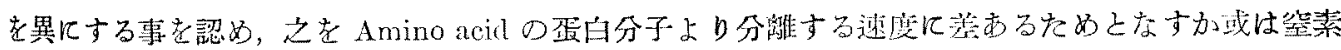
結合狀態に變化を來せしによるものとなすかいづれなるか子知らんとせり，且䣼素の作用が $\mathrm{pH}$

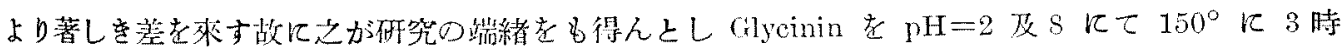

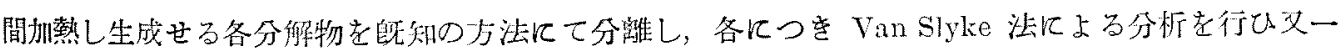

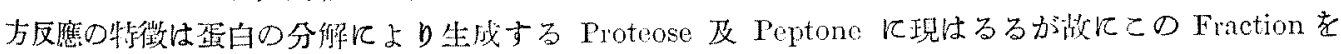
Kingston-Schryer 法によりAmino acid の分析を行ひたり，その絬果は第三十八及三十九表に示方 如L.

第三十八表 A. Van slyke 法长上分分析

\begin{tabular}{|c|c|c|c|c|c|c|}
\hline $\mathrm{pH}$ & \multirow{2}{*}{ Glycinin } & \multicolumn{2}{|c|}{2} & \multicolumn{3}{|c|}{8} \\
\hline Fraction & & Insol. sub. & Proteose & Metaprotein & Proteose & Peptone \\
\hline Amide $\mathrm{N}$ & 11.9 & $\begin{array}{r}\% \\
5.4\end{array}$ & $\begin{array}{r}\% \\
6.8\end{array}$ & $\begin{array}{c}\% \\
5.7\end{array}$ & $\begin{array}{c}\% \\
7.2\end{array}$ & $\begin{array}{r}\% \\
43.1\end{array}$ \\
\hline Humin $\triangle$ & 1.7 & 3.1 & 1.0 & 2.4 & 2.2 & - \\
\hline Diamino $\mathrm{N}$ & 24.0 & 23.1 & 29.9 & 22.5 & 25.6 & 9.7 \\
\hline Arginine $X$ & 13.95 & 12.9 & 16.9 & 13.1 & 14.4 & 3.5 \\
\hline Histidine 1 & 0.79 & 0.8 & 0.8 & 0.2 & 1.3 & 1.2 \\
\hline Lysine N & 9.26 & 9.3 & 12.2 & 9.2 & 9.9 & 5.0 \\
\hline Monoamino $\mathrm{N}$ & 62.1 & 65.0 & 61.1 & 69.0 & 64.8 & 47.2 \\
\hline
\end{tabular}


符三十八表 B. 同, Diamino acid の比

\begin{tabular}{l|c|c|c|c|c|c}
\hline \multicolumn{1}{c|}{$\mathrm{pH}$} & \multirow{2}{*}{ Glycinin } & \multicolumn{2}{|c|}{2} & \multicolumn{3}{c}{8} \\
\cline { 3 - 7 } Fraction & & Insol. sub. & Proteose & Metaprotein & Proteose & Peptone \\
\hline Mrginine $\mathrm{N}$ & $58 \%$ & $56 \%$ & $56 \%$ & $58 \%$ & $56 \%$ & $36 \%$ \\
Histidine $\mathrm{N}$ & 3 & 4 & 3 & 1 & 5 & 13 \\
Lysine $\mathrm{X}$ & 39 & 40 & 41 & 41 & 39 & 51 \\
\hline
\end{tabular}

籐三十九表 A. Kingston-Schryver 法による分析

\begin{tabular}{|c|c|c|c|c|c|}
\hline $\mathrm{pH}$ & \multirow{2}{*}{ Glycinin } & \multicolumn{2}{|c|}{2} & \multicolumn{2}{|c|}{8} \\
\hline Fraction & & Proteose & Pejotone & Proteose & Peptone \\
\hline Amide X & - & - & $38.1 \%$ & $6.5 \%$ & $35.0 \%$ \\
\hline Humin $\mathrm{N}$ & $0.7 \%$ & $0.3 \%$ & - & 0.3 & 0.3 \\
\hline Diamino $N$ & 24.3 & 30.9 & 9.5 & 25.5 & 15.9 \\
\hline Arginine $N$ & 12.6 & 13.5 & 3.0 & 11.6 & 6.5 \\
\hline Histiline $\mathrm{X}$ & 2.6 & 3.0 & 1.6 & 2.9 & 2.4 \\
\hline Lysine $N$ & 8.3 & 8.3 & 3.9 & 10.5 & 9.0 \\
\hline Diearboxylic acid $\mathrm{N}$ & 13.2 & 6.0 & 6.2 & 7.9 & 5.1 \\
\hline Tyrosine $N$ & 1.5 & 0.9 & 0 & 1.5 & 0 \\
\hline Monomino $\mathrm{X}$ & 43.1 & 51.4 & 37.5 & 52.8 & 40.7 \\
\hline
\end{tabular}

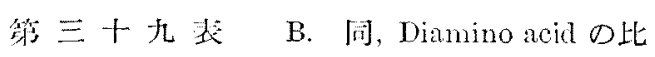

\begin{tabular}{|c|c|c|c|c|c|}
\hline $\mathrm{pH}$ & \multirow{2}{*}{ Glyeinin } & \multicolumn{2}{|c|}{2} & \multicolumn{2}{|c|}{8} \\
\hline Fraction & & Proteose & Peptone & Proteose & Peptone \\
\hline Arginine $\mathrm{N}$ & $\begin{array}{l}\% \\
53\end{array}$ & $\begin{array}{l}\% \\
54\end{array}$ & $\begin{array}{l}\% \\
36\end{array}$ & $\begin{array}{l}\% \\
47\end{array}$ & $\begin{array}{l}\% \\
\% \\
3 \bar{i}\end{array}$ \\
\hline Histidine $N$ & 12 & 12 & 18 & 11 & 13 \\
\hline Lysine $N$ & 35 & 34 & 46 & 40 & 50 \\
\hline
\end{tabular}

Diamino acid につぜてるに不溶物筫, Metaprotein, Proteose に於てはその總量には變化するも

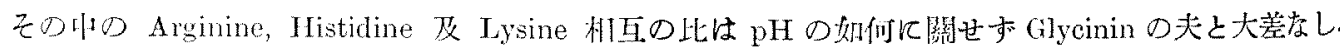
然るに Peptone に於ては pH の如何に拘ら禾 Diamino acid 總量の減少するのみならす，その三者の

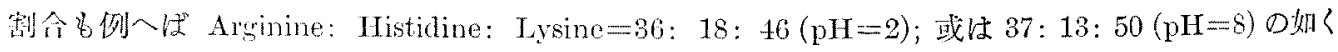

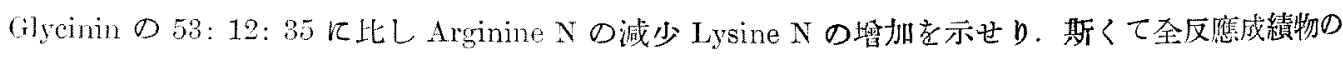

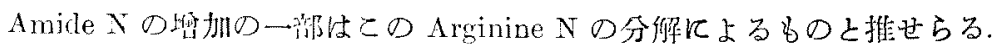

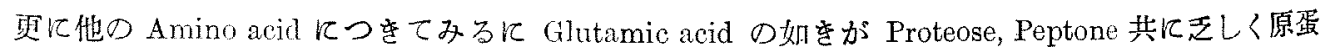

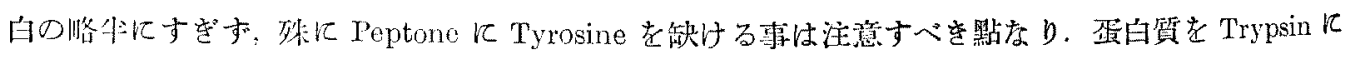

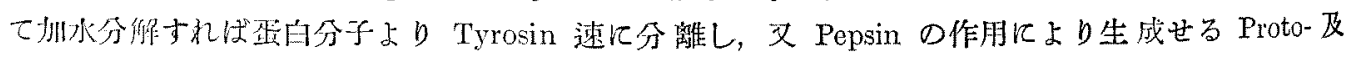




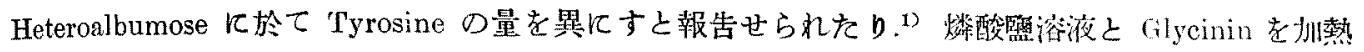
せし時㔻白分子よりのAmino acid の分踓が各段階に於て異り Tyrosine 及 Glutamic acid が特殊の 關係にあるは酵素の作用と對哭し興味あるものと謂ふへし.

(5) Metaprotein 及 Proteose に對する過熱水の作用

Glycinin は上述の如く過熱水の作用に上り扠水分解を弓け Metaprotein, Proteose, Peptone 等を生

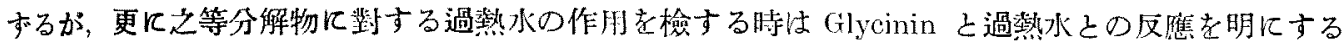
第 四十裴 Metaprotein $\left(150^{\circ}, 3\right.$ 時间)

\begin{tabular}{|c|c|c|c|c|c|c|}
\hline $\begin{array}{ll}\mathrm{pH} & \text { (反 } \\
\mathrm{pH} & \text { 仮 }\end{array}$ & 應 & $\begin{array}{l}\text { 前) } \\
\text { 後) }\end{array}$ & 糊) & $\begin{array}{l}2.0 \\
2.6\end{array}$ & $\begin{array}{l}5.1 \\
3.8\end{array}$ & $\begin{array}{l}8.0 \\
6.4\end{array}$ \\
\hline $\mathrm{NH}_{2}-\mathrm{N}$ & & & $3.0 \%$ & $21 \%$ & $14 \%$ & $11 \%$ \\
\hline
\end{tabular}

第四十一表 Metaprotein $\left(150^{\circ}, 3\right.$ 時阳 $)$

\begin{tabular}{c|c|c|c}
\hline \multicolumn{1}{c|}{$\mathrm{pH}$} & 2.0 & 5.1 & 8.0 \\
\hline Insol.-N & & & $5 \%$ \\
Metaprotein N & $17 \%$ & $20 \%$ & 35 \\
Proteose-N & 4 & 30 & 31 \\
Peptone N & 40 & 41 & 29 \\
\hline Proteose: Peptone & $50: 50$ & $40: 60$ & $51: 49$ \\
\hline
\end{tabular}

所あるへしと考へGlycinin を水之共に $150^{\circ}$ に 3 時间为熱して生成せ

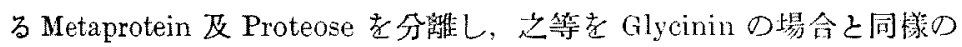

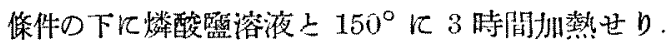

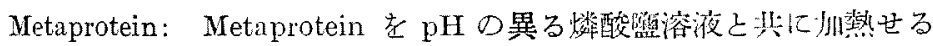

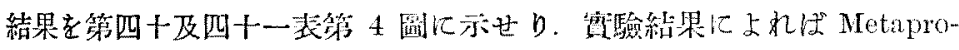
tein は過熱水に上り扣水分船を5け Proteose, Peptone 老生委る外不溶 物質を生成し，乙の變化の度壮 $\mathrm{pH}=2$ の睦汥大にして $96 \% ; \mathrm{pH}=5$,

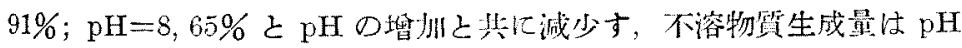
$=2$ の時 $17 \%, \mathrm{pH}=8$ にて 5\%; $\mathrm{NH}_{\mathrm{g}} \mathrm{N}$ は $\mathrm{pH}=2,21 \% ; \mathrm{pH}=5,14 \%$ ； $\mathrm{pH}=8,11 \%$ にして $\mathrm{pH}$ の小孝る程不溶物質生成及扠水分解大なり，又 Wasteneys 及 Borsook 法によりて可塎物筑を分别せる結果 \& Proteose 及 Peptone の生成 $\mathrm{pH}=2$ にて最大にして $\mathrm{pH}$ の增加に從し滅少せり.

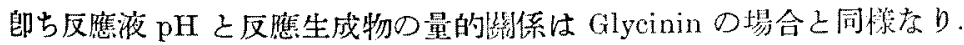

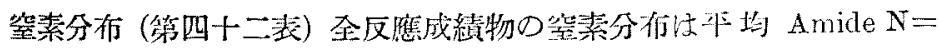
10\%; Diamino $\mathrm{N}=20 \%$; Monoamino $\mathrm{N}=66 \%$ にして原試料の Amide $\mathrm{N}=7 \%$; Diamino $\mathrm{N}=21 \%$; Monoamino $N=70 \%$ K比し, Amide ND

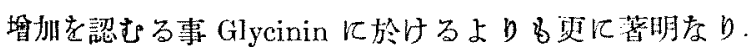

不溶物質に於てはいづれの場合子 Amide Xは原試料比比し減少し Monoamino $\mathrm{N}$ : Diamino $\mathrm{N}$ は $\mathrm{pH}=2$ にては 4.5 にして試料より著しく 大なる多 $\mathrm{pH}=5.1$ にては 3.1 にして原試料と大差なし.

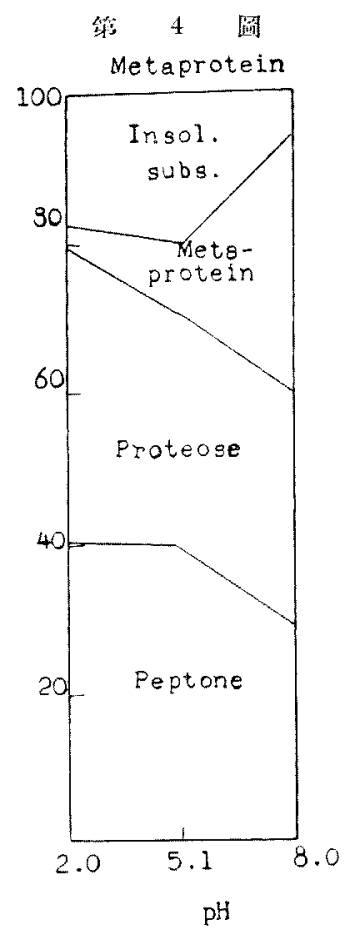

1) Mitchell, Hamilton: 'Biochemistry of amino acids' (1929), 214; Siegfried: 'Partielle Eiweisshydrolyse' (1916), 3. 
第四十二表䇪素分妳

\begin{tabular}{|c|c|c|c|c|c|c|c|c|c|c|}
\hline & $\mathrm{pH}$ & (Metaprotein) & 2.0 & 5.1 & 8.0 & & $\mathrm{pH}$ & 2.0 & 5.1 & 8.0 \\
\hline \multirow{5}{*}{ 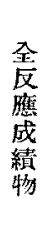 } & Amide $x$ & $\begin{array}{l}\% \\
\% 1.1\end{array}$ & $\begin{array}{r}\% \\
10.3\end{array}$ & $\%$ & $\begin{array}{r}\% \\
10.1\end{array}$ & \multirow{5}{*}{ 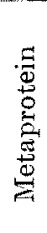 } & Amide $\mathrm{N}$ & $\begin{array}{c}\% \\
3.9 \\
\end{array}$ & $\begin{array}{l}9 \% \\
5.4\end{array}$ & $\begin{array}{l}\% \\
5.1\end{array}$ \\
\hline & Humin $N$ & 1.7 & 3.2 & 4.1 & 2.2 & & Humin $\mathrm{N}$ & 6.2 & 6.0 & - \\
\hline & Diamino $N$ & 21.2 & 21.3 & 20.0 & 19.3 & & Diamino $\mathrm{N}$ & 22.2 & 20.9 & 19.7 \\
\hline & Monoamino N & 70.5 & 64.4 & 64.8 & 67.9 & & Monoamino $\mathrm{N}$ & 70.0 & 65.0 & 70.7 \\
\hline & $\begin{array}{c}\text { Monoamino } N: \\
\text { Diamino }\end{array}$ & 5.3 & 3.0 & 3.2 & 3.5 & & $\begin{array}{l}\text { Monoamino } N \text { : } \\
\text { Diamino } N\end{array}$ & 3.2 & 3.1 & 3.5 \\
\hline \multirow{5}{*}{$\begin{array}{l}\text { 不 } \\
\text { 溶 } \\
\text { 物 } \\
\text { 澌 }\end{array}$} & A unide $Y$ & $\begin{array}{c}\text { (Glycinin) } \\
13.7\end{array}$ & 3.9 & 4.4 & - & \multirow{5}{*}{ 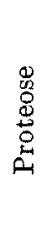 } & Amide $\mathrm{N}$ & 4.2 & 5.7 & 5.8 \\
\hline & Humin $\mathrm{N}$ & 0.8 & 6.6 & 6.1 & - & & Humin $N$ & 1.7 & 2.3 & 4.1 \\
\hline & Diamino $x$ & 22.1 & 15.7 & 21.8 & - & & Diamino $N$ & 30.3 & 29.5 & 26.7 \\
\hline & Monoamino $\mathrm{N}$ & 62.6 & 72.3 & 67.0 & - & & Monoamino $\mathrm{N}$ & 63.7 & 63.2 & 63.4 \\
\hline & $\begin{array}{l}\text { Monoamino N: } \\
\text { Diamino } N\end{array}$ & 2.9 & 4.5 & 3.1 & - & & $\begin{array}{c}\text { Monoamino N: } \\
\text { Diamino } N\end{array}$ & 2.1 & 2.2 & 2.4 \\
\hline \multirow{5}{*}{$\begin{array}{l}\text { 可 } \\
\text { 溶 } \\
\text { 物 } \\
\text { 䝷 }\end{array}$} & Amide $x$ & & 12.2 & 11.2 & 10.1 & \multirow{5}{*}{ 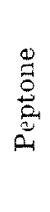 } & Amide $\mathrm{N}$ & 28.1 & 23.7 & - \\
\hline & Humin $N$ & & 2.2 & 3.4 & 2.2 & & Humin $\mathrm{N}$ & 1.3 & 1.2 & - \\
\hline & Diamino $x$ & & 22.9 & 19.3 & 19.3 & & Diamino $\mathrm{N}$ & 16.9 & 10.4 & - \\
\hline & Monoamino $N$ & & 62.1 & 64.0 & 67.9 & & Monoamino $\mathrm{N}$ & 52.7 & 61.9 & - \\
\hline & $\begin{array}{l}\text { Monoamino N: } \\
\text { Diamino }\end{array}$ & & 2.8 & 3.3 & 3.5 & & $\begin{array}{c}\text { Monoamine N: } \\
\text { Diamino N }\end{array}$ & 2.8 & 3.3 & - \\
\hline
\end{tabular}

可溶物質の紫菜分有は作均 Amide $\mathrm{N}=11 \%$ ；Diamino $\mathrm{N}=21 \%$ ；Monoamino $\mathrm{N}=65 \%$ にして常に Amide N の增州を認むるも Monoamino N：Diamino N は不溶物筫に於けると反對に $\mathrm{pH}=2$ の時娍 少し $\mathrm{pH}=8$ の時傗加せ $り$.

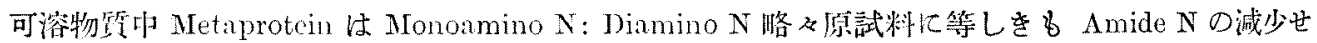
るは注億すへし.

Proteose は体詓 Amide $N=5.1 \%$; Diamino $N=30 \%$; Monoamino $N$ : Diamino $N=2.2$ Kして原

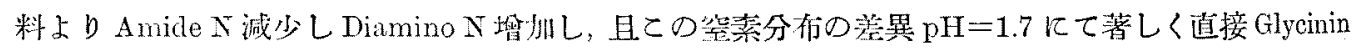

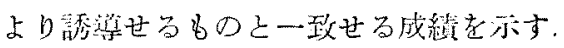

Peptone 以下に於て Amide $\mathrm{X}(=25 \%)$ 增版し, Diamino N $(=15 \%)$ 減少し $\mathrm{pH}=2$ の場合塋素分 们行督化孝示せり。

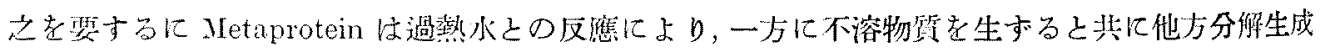

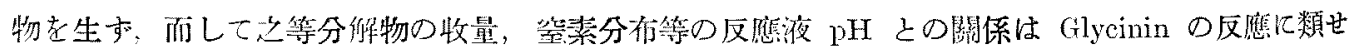
b.

第四十三表 Proteose $\left(150^{\circ}, 3\right.$ 時间)

\begin{tabular}{|c|c|c|c|c|c|c|c|}
\hline $\mathrm{pH}$ & （反 & 應 & 前) & \multirow{2}{*}{ 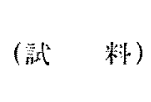 } & 1.8 & 4.8 & 8.4 \\
\hline $\mathrm{pH}$ & （反 & 殿 & 後) & & 2.6 & 5.1 & 6.5 \\
\hline \multicolumn{4}{|c|}{$\mathrm{NH}_{\underline{z}}-\mathrm{N}$} & $6.2 \%$ & $24.5 \%$ & $12.2 \%$ & $15.5 \%$ \\
\hline
\end{tabular}


第四十四表 Proteose $\left(150^{\circ}, 3\right.$ 時间)

\begin{tabular}{|c|c|c|c|}
\hline $\mathrm{pH}$ & 1.8 & 4.8 & 8.4 \\
\hline Proteose-N & $43 \%$ & $57 \%$ & $87 \%$ \\
\hline $\begin{array}{l}\text { Insol.-N } \\
\text { Metaprotein-N } \\
\text { Peptone-N }\end{array}$ & $\begin{array}{l}1.2 \% \\
0 \\
56\end{array}$ & $\begin{array}{l}0.6 \% \\
3.6 \\
39\end{array}$ & $\begin{array}{l}0.5 \% \\
1.6 \\
12\end{array}$ \\
\hline
\end{tabular}

Proteose: Proteose は過㷫水と作用し抈水分解をうけ, Peptone 等

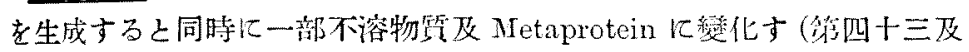
四十四表, 第5 國). 而して Proteose の變化してる量壮 $\mathrm{pH}=1.8$ の時 最大にして $57 \%, \mathrm{pH}=1.8$ 乙に次ざ $43 \%, \mathrm{pH}=8.1$ 最小にして $13 \%$ な るが $\mathrm{NH}_{2-\mathrm{N}}$ は $\mathrm{pH}=1.8,25 \% ; \mathrm{pH}=5,12 \% ; \mathrm{pH}=8.4,16 \%$, Peptone 生成量は $\mathrm{pH}=1.8,56 \% ; \mathrm{pH}=4.5,39 \% ; \mathrm{pH}=8.4,12 \%$ にして $\mathrm{pH} の$ 小なる程加水分解の度大なるを知る。

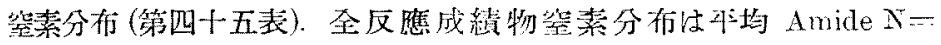
10\%; Liamino $\mathrm{X}=22 \%$; Monoamino $\mathrm{N}=62 \%$ にして pH の吙何なる 場合子 Amide $\mathrm{N}$ 菂加L Diamino $\mathrm{N}$ 及 Monoamino $\mathrm{N}$ 減少与. Amide $\mathrm{N}$ の增为仕 $\mathrm{pH}=1.8$ にて著しきがMonoamino $\mathrm{N}$ : Diamino $\mathrm{N}$ は $\mathrm{pH}=1.8$ にて 2.5, $\mathrm{pH}=4.8$ 及 8.4 にて 2.9 となり, $\mathrm{pH}$ により Amide $\mathrm{N}$ 墦扠の 原因索異にするを暗示す

次反應成績物中の Proteose 及 Amide $\mathrm{N}=6 \%$; Diamino $\mathrm{N}=23 \%$; Monoamino $X$ : Diamino $\mathrm{N}=2.8$ にして原料 Proteose ょり Amide $\mathrm{N}$ 及

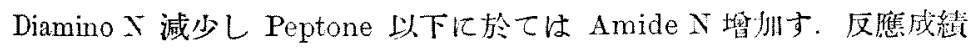
物中 Proteose 及 Peptone の垤菜分扔は Glycinin 或は Metaprotein より 誘導せるもの之多少の差あり．今之を比較するに第四十六表に示す如 くGlycinin, Metaprotein 及 Proteose を原料とするに從し，漸次兩者の 空素分布の差減少し Peptone 以下の分解物の Amide N は 42, 28, 18 $(\mathrm{pH}=2)$; 或は $34,24,23(\mathrm{pH}=8)$ と減少し, Diamino $\mathrm{N}$ 注 $12,17,23$ $(\mathrm{pH}=2)$; 或は $11,10,16(\mathrm{pH}=8)$ 乙增㧈す. 即 Amide $\mathrm{N}$ の分䠊法蛋白

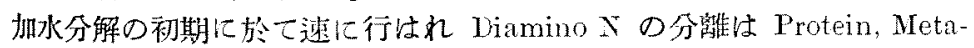

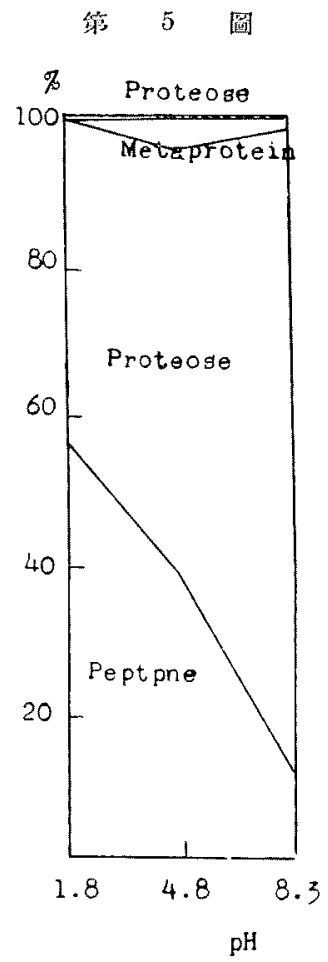
protein, Proteose と次第に容易となるを示すものなるへし。

\section{要 約}

1）大豆より蛋白質 Albumin, Glycinin (GJobulin) 及 Glutelin 老分離し且その性質を檢せり.

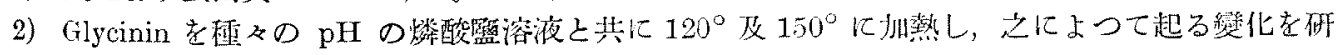
笁LGlycinin は過熱水に上り不溶物質之可溶物質を生じ, 可溶物筫は Metaprotein, Proteose, Peptone 等よりなり，之等成績物は反應液の $\mathrm{pH} に よ り$ 相違する明にせり。

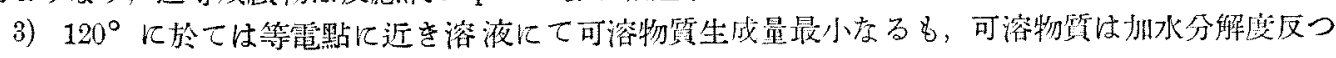
て大にして下級分解物多量なり。

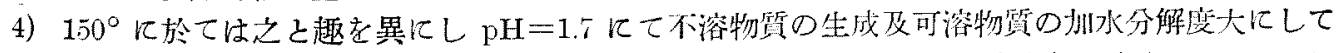

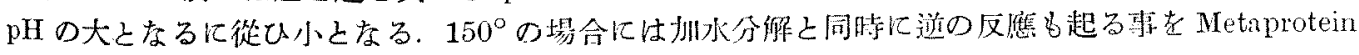
及 Proteose 江對する過熱水の作用により確めをり。 
第四十五表窒素分布 (Proteose, $150^{\circ}, 3$ 時間)

\begin{tabular}{|c|c|c|c|c|c|}
\hline & $\mathrm{pH}$ & Proteose & 1.8 & 4.8 & 8.4 \\
\hline 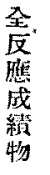 & $\begin{array}{l}\text { Amide-N } \\
\text { Humin-N } \\
\text { Diamino } N \\
\text { MonoaminoN } \\
\text { Monoamino-N: Diamino-N }\end{array}$ & $\begin{array}{l}8.7 \% \\
1.4 \\
25.0 \\
60.8 \\
2.4\end{array}$ & $\begin{array}{l}12.0 \% \\
23.7 \\
28.5 \\
2.5\end{array}$ & $\begin{array}{c}9.3 \% \\
21.7 \\
63.3 \\
2.9\end{array}$ & $\begin{array}{c}9.3 \% \\
21.7 \\
63.3 \\
2.9\end{array}$ \\
\hline 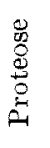 & $\begin{array}{l}\text { Amide } N \\
\text { Humin } N \\
\text { Diamino } N \\
\text { Monoamino } N \\
\text { Monoamino } N \text { :Diamino } N\end{array}$ & & $\begin{array}{r}4.7 \\
1.8 \\
24.4 \\
67.4 \\
2.8\end{array}$ & $\begin{array}{r}6.6 \\
2.5 \\
22.5 \\
62.7 \\
2.8\end{array}$ & $\begin{array}{r}7.7 \\
3.2 \\
22.9 \\
65.4 \\
2.8\end{array}$ \\
\hline 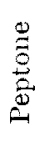 & $\begin{array}{l}\text { Amide N } \\
\text { Humin N } \\
\text { Diamino N } \\
\text { Monoamino N } \\
\text { Monoamino N: Diamino }\end{array}$ & & $\begin{array}{r}17.9 \\
2.2 \\
23.2 \\
51.5 \\
2.2\end{array}$ & $\begin{array}{r}20.7 \\
1.4 \\
20.6 \\
56.1 \\
2.7\end{array}$ & $\begin{array}{r}22.5 \\
1.6 \\
16.3 \\
58.5 \\
3.6\end{array}$ \\
\hline
\end{tabular}

第四十六斐 Proteose 己 Peptoneの空菜分布比洨

\begin{tabular}{|c|c|c|c|c|c|}
\hline \multirow{2}{*}{ 原䊅 } & $\mathrm{pH}$ & \multicolumn{2}{|c|}{1.8} & \multicolumn{2}{|c|}{8.0} \\
\hline & Fraction & Proteose & Peptone & Proteose & Peptone \\
\hline 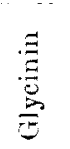 & $\begin{array}{l}\text { Amide } \mathrm{N} \\
\text { Diamino } \mathrm{N} \\
\text { Monoamino } \mathrm{N} \\
\text { Monoamino } \mathrm{N} \text { : Diamino } \mathrm{N}\end{array}$ & $\begin{array}{r}\% \\
6.4 \\
28.5 \\
63.5 \\
2.2\end{array}$ & $\begin{array}{l}41.9 \% \\
12.3 \\
46.5 \\
3.7\end{array}$ & $\begin{array}{l}9.4 \% \\
27.0 \\
65.5 \\
2.5\end{array}$ & $\begin{array}{l}33.8 \% \\
11.1 \\
50.7 \\
4.6\end{array}$ \\
\hline 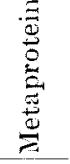 & $\begin{array}{l}\text { Amide } \mathrm{N} \\
\text { Diamino } \mathrm{N} \\
\text { Monoamino } \mathrm{N} \\
\text { Monoamino } \mathrm{N} \text { : Diamino } \mathrm{N}\end{array}$ & $\begin{array}{r}4.2 \\
30.3 \\
63.7 \\
2.1\end{array}$ & $\begin{array}{r}28.1 \\
16.9 \\
52.7 \\
3.1\end{array}$ & $\begin{array}{r}5.7^{*} \\
29.5^{*} \\
63.2^{*} \\
2.2^{*}\end{array}$ & $\begin{array}{r}23.7^{*} \\
10.4^{*} \\
61.9^{*} \\
6.0^{*}\end{array}$ \\
\hline 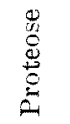 & $\begin{array}{l}\text { Amide } \mathrm{N} \\
\text { Diamino } \mathrm{N} \\
\text { Monoamino } \mathrm{N} \\
\text { Monoamino } \mathrm{N}: \text { Diamino } \mathrm{N}\end{array}$ & $\begin{array}{r}4.7 \\
24.4 \\
67.4 \\
2.8\end{array}$ & $\begin{array}{r}17.9 \\
23.2 \\
51.5 \\
2.2\end{array}$ & $\begin{array}{r}7.7 \\
22.9 \\
65.4 \\
2.8\end{array}$ & $\begin{array}{r}22.5 \\
16.3 \\
58.4 \\
3.6\end{array}$ \\
\hline
\end{tabular}

* $\mathrm{pH}=5.1$

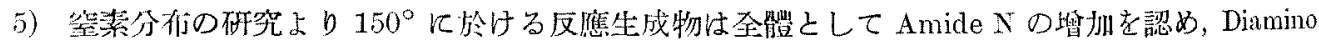

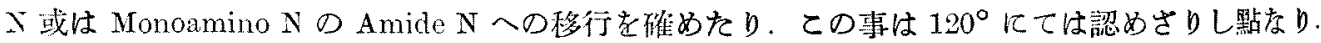

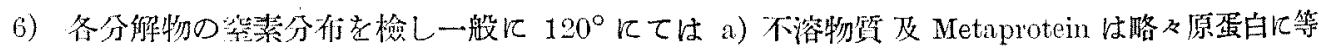
しく b) Proteose は Diamino N に富み c) Peptone は Amide N 及 Mononmino N 多く Diamino N 少

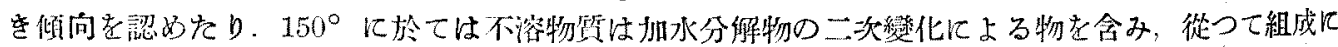

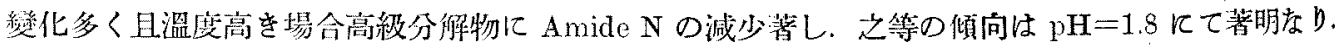

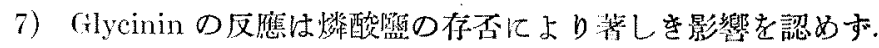

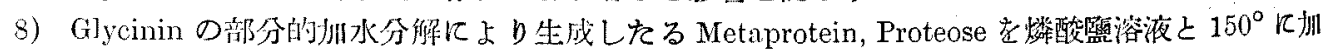

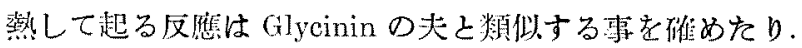

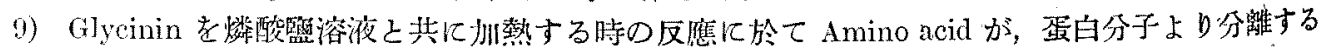

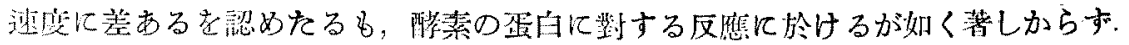




\section{實驗之部 \\ I 大豆蛋白質の調製}

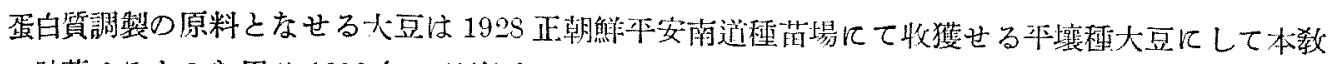

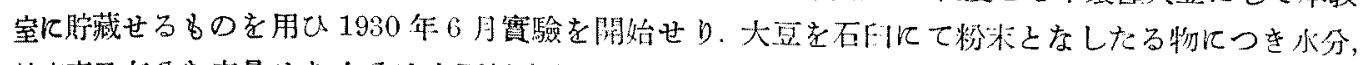

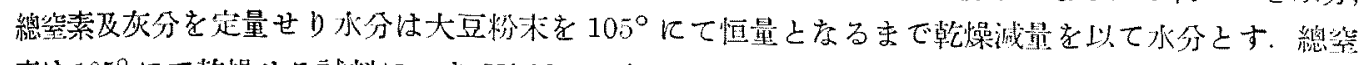

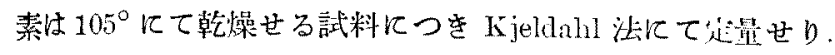

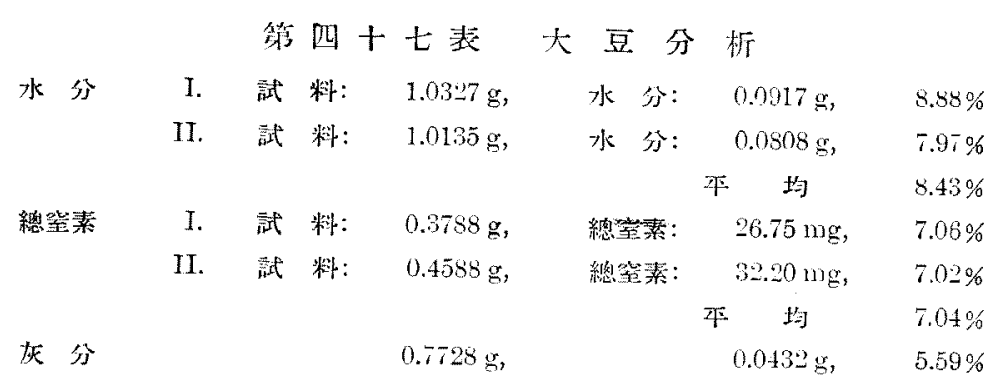

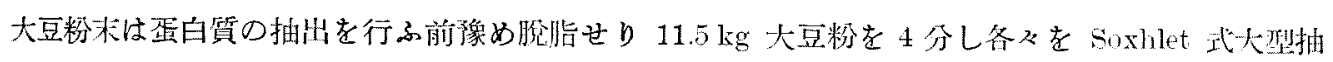

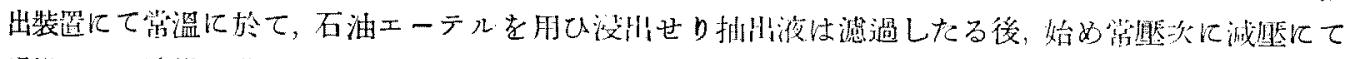

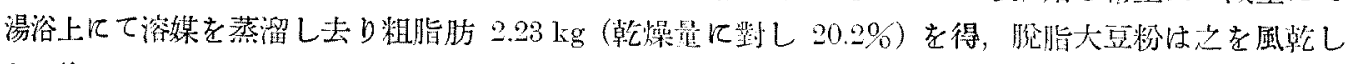
える後 $9.3 \mathrm{~kg}$ 得をり。

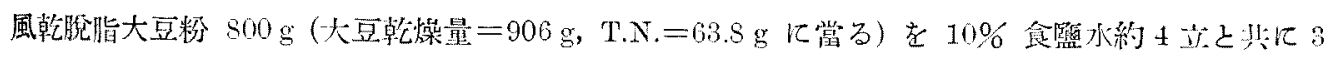

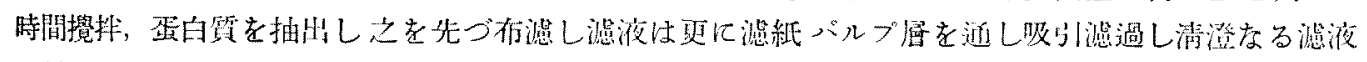

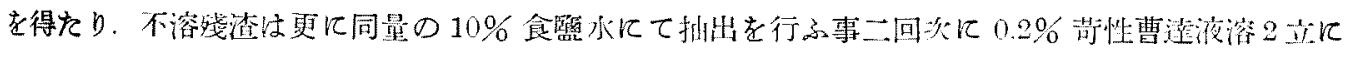

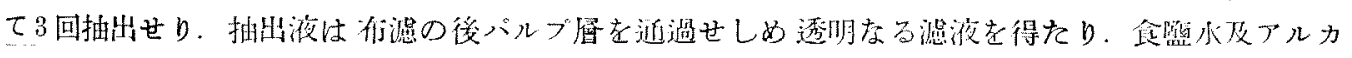

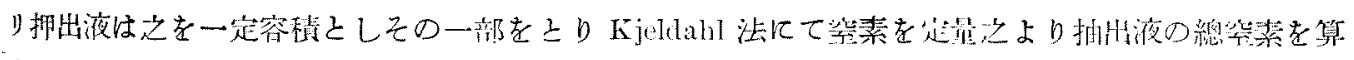
定せ り.

第四十八表

\begin{tabular}{|c|c|c|c|c|}
\hline$\ldots \ldots$ & I & II & III & 計 \\
\hline 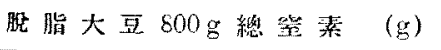 & & & & 906 \\
\hline 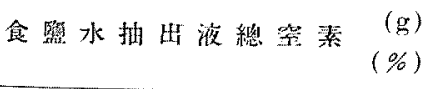 & $\begin{array}{l}29.3 \\
45.8\end{array}$ & $\begin{array}{l}10.8 \\
17.0\end{array}$ & $\begin{array}{r}66 \\
10.4\end{array}$ & $\begin{array}{l}46.7 \\
73.2\end{array}$ \\
\hline フルカy抽出液總䇺素 $(\mathrm{g})$ & $\begin{array}{l}3.7 \\
5.8\end{array}$ & $\begin{array}{l}2.2 \\
8.5\end{array}$ & $\begin{array}{l}1.5 \\
2.3\end{array}$ & $\begin{array}{r}7.4 \\
11.6\end{array}$ \\
\hline
\end{tabular}

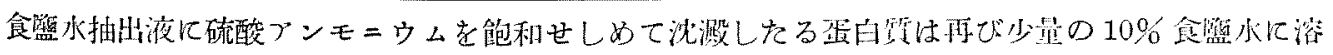

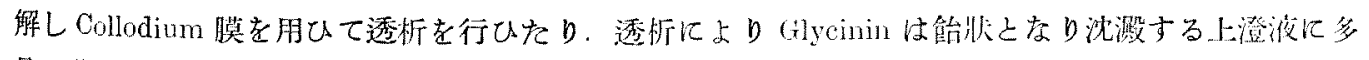

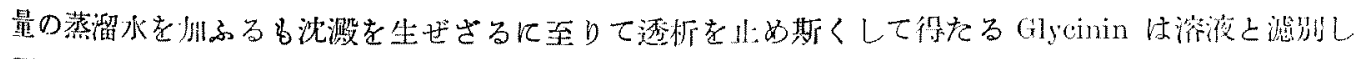

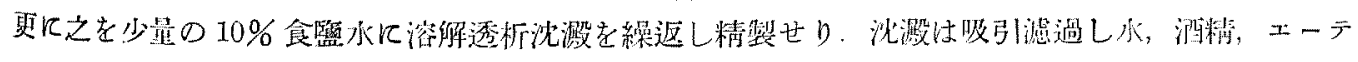
ルにて洗涤宾空乾燥器にて乾燥す

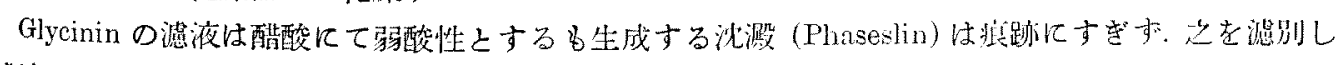

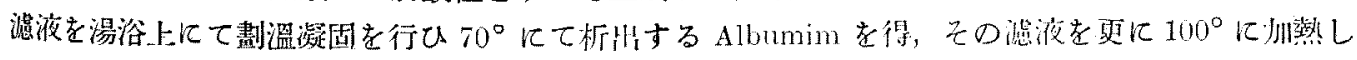




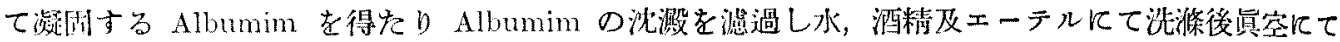
乾燥す。

Glutelin 在有するナルカリ扗出液は酢酸にて弱酸性とし沈澱せる蛋白質を $0.2 \mathrm{~N}$ アルカリに溶解,

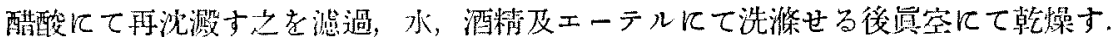

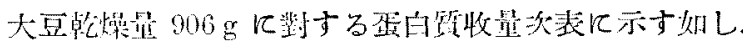

符四十九表

Glycinin

Phaseolin

Albumin ( $70^{\circ}$ 凝固)

Albumin ( $100^{\circ}$ 㠜园

Glutelin

$\begin{array}{rr}58 & \text { 牧 } \\ \begin{array}{r}\% \\ \text { 痕跡 }\end{array} & - \\ 4.5 & 0.5 \\ 1.0 & 0.1 \\ 5.0 & 0.6\end{array}$

\section{II 大豆蛋白質の性狀}

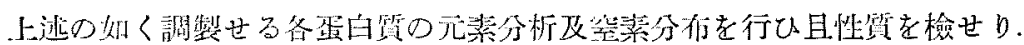

1) Albumim.

元素分析

你五十表 Albumin $\left(70^{\circ}\right.$ 倁间)

\begin{tabular}{|c|c|c|c|c|c|c|c|}
\hline & 試 糊 & $\mathrm{CO}_{2}$ & $\mathrm{H}_{2} \mathrm{O}$ & 灰 分 & $\mathrm{C}$ & $\mathrm{H}$ & 灰分 \\
\hline I & $0.187 \%$ & $0.371 \stackrel{g}{1}$ & 0.1210 & $g$ & $\begin{array}{r}\% \\
53.94\end{array}$ & $\begin{array}{r}\% \\
7.14\end{array}$ & $\%$ \\
\hline II & 0.1880 & 0.3683 & 0.1206 & 0.0008 & 53.40 & 7.13 & 0.42 \\
\hline 平均 & & & & & 53.67 & 7.14 & 0.42 \\
\hline
\end{tabular}

第五. + - 裴 $\quad$ Albunin $\left(100^{\circ}\right.$ 凝固 $)$

\begin{tabular}{|c|c|c|c|c|c|c|c|}
\hline & 試 料 & $\mathrm{CO}_{2}$ & $\mathrm{H}_{2} \mathrm{O}$ & 灰 分 & $\mathrm{C}$ & $\mathrm{H}$ & 灰分 \\
\hline I & $\begin{array}{r}\mathrm{g} \\
0.2090 \overline{5}\end{array}$ & 0.4120 & 0.1938 & $\underline{-}$ & $\begin{array}{r}\% \\
53.65\end{array}$ & $\begin{array}{r}\% \\
7.05\end{array}$ & $\%$ \\
\hline II & 0.2410 & 0.4690 & 0.1567 & - & 53.07 & 6.93 & - \\
\hline 平均 & & & & , & 53.36 & 6.99 & - \\
\hline
\end{tabular}

\section{總 架菜 Kjeldahl 法にて定量せり}

第五. 三表 Albumin

\begin{tabular}{|c|c|c|c|c|c|c|}
\hline & \multicolumn{3}{|c|}{ Albumin ( $70^{\circ}$ 㠜固) } & \multicolumn{3}{|c|}{ Albumin ( $100^{\circ}$ 㠜固) } \\
\hline & 普粹 & 篗 & 素 & 試料 & 䇪 & 素 \\
\hline I & 0.1281 & $\begin{array}{r}\text { ing } \\
20.30\end{array}$ & $\begin{array}{r}\% \\
15.72\end{array}$ & $0.1490 \overline{\mathbf{g}}$ & $\begin{array}{r}\mathrm{mg} \\
23.50\end{array}$ & $\begin{array}{r}\% \\
15.72\end{array}$ \\
\hline II & 1.1051 & 16.78 & 15.96 & 0.1698 & 26.70 & 15.72 \\
\hline 平均 & & & 15.84 & & & 15.72 \\
\hline
\end{tabular}




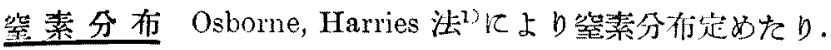

\begin{tabular}{|c|c|c|c|c|}
\hline \multirow[b]{2}{*}{ 試＼cjkstart料 } & \multicolumn{2}{|c|}{ Albumin ( $70^{\circ}$ 凝圆) } & \multicolumn{2}{|c|}{ Albumin $\left(100^{\circ}\right.$ 凝圆) } \\
\hline & $\operatorname{mg}_{596.6}$ & $\%$ & $\frac{\mathrm{mg}}{973.3}$ & $\%$ \\
\hline T. N. & 94.50 & - & 153.0 & - \\
\hline Amide & 8.22 & 8.7 & 13.15 & 8.6 \\
\hline Humin & 6.90 & 7.3 & 6.28 & 4.1 \\
\hline Diamino $\mathrm{N}$ & 18.58 & 19.7 & 31.15 & 20.4 \\
\hline Monoamino N & 59.5 & 63.0 & 101.5 & 66.3 \\
\hline
\end{tabular}

2) Glycinin.

元素分析

第五十四表 Glycinin

\begin{tabular}{|c|c|c|c|c|c|c|c|}
\hline & 試 料 & $\mathrm{CO}_{2}$ & $\mathrm{H}_{2} \mathrm{O}$ & 灰 分 & $\mathrm{C}$ & $\mathrm{H}$ & 灰 分 \\
\hline I & $\begin{array}{r}g \\
0.1888\end{array}$ & $\begin{array}{r}\mathrm{g} \\
0.3655\end{array}$ & $0.12 ; 7^{g}$ & 0.0010 & $\begin{array}{r}\% \\
52.80\end{array}$ & $\begin{array}{r}\% \\
7.57\end{array}$ & $\begin{array}{r}\% \\
0.53\end{array}$ \\
\hline II & 0.2065 & 0.4005 & 0.1414 & 0.0012 & 52.89 & 7.66 & 0.58 \\
\hline III & 0.1855 & 0.3587 & 0.1253 & 0.0008 & 52.71 & 7.56 & 0.43 \\
\hline IV & 0.1847 & 0.3569 & 0.1230 & 0.0012 & 52.70 & 7.45 & 0.65 \\
\hline 平 均 & & & & & 52.75 & 7.56 & 0.55 \\
\hline
\end{tabular}

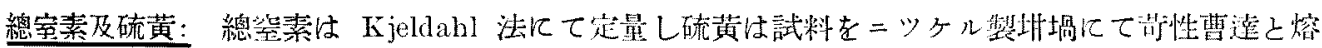

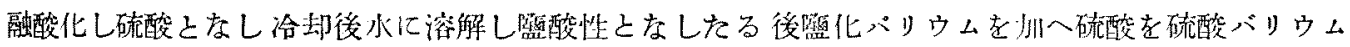
として科量之より硫黄の量を求めたり。

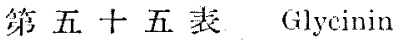

\begin{tabular}{|c|c|c|c|c|c|}
\hline & 試 科 & \multicolumn{2}{|c|}{$N$} & $\mathrm{BaSO}_{4}$ & $\mathrm{~S}$ \\
\hline I & 0.2013 & $\begin{array}{r}\mathrm{mg} \\
34.46^{\circ}\end{array}$ & $\begin{array}{r}\% \\
17.12\end{array}$ & & \\
\hline II & 0.0968 & 17.03 & 17.03 & & \\
\hline III & 0.7999 & & & 0.0438 & $\begin{array}{r}\% \\
0.75\end{array}$ \\
\hline IV & 0.6866 & & & 0.0358 & 0.71 \\
\hline 平 均 & & & 17.08 & & 0.73 \\
\hline
\end{tabular}

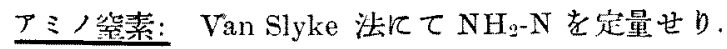

第五十六表 Glycinin

\begin{tabular}{|c|c|c|c|}
\hline T.N. & $\mathrm{N}_{2}$ & \multicolumn{2}{|c|}{$\mathrm{NH}_{2}-\mathrm{N}$} \\
\hline $20.81 \mathrm{mg}$ & $0.94 \mathrm{cc}\left(23^{\circ}, 761 \mathrm{~mm}\right)$ & $0.53 \mathrm{rng}$ & $2.6 \%$ \\
\hline
\end{tabular}

1) 前出; Hoppe-Syler, Thierfelder: 'Handbuch der physiol.- u. path.-chemischen Analyse' (9. Aufl., 1924) 587. 


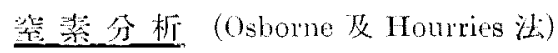

第五十七表 Glycinin

\begin{tabular}{|c|c|c|c|c|c|c|c|c|c|c|}
\hline & 試 & T.N. & \multicolumn{2}{|c|}{ Amide $N$} & \multicolumn{2}{|c|}{ Humino $N$} & \multicolumn{2}{|c|}{ Diemino $N$} & \multicolumn{2}{|c|}{ Monoemin N } \\
\hline $\mathrm{I}$ & 0.8007 & $\begin{array}{r}\mathrm{mg} \\
153.9\end{array}$ & $\begin{array}{r}\mathrm{mg} \\
20.64\end{array}$ & $\begin{array}{r}\% \\
13.41\end{array}$ & $\begin{array}{l}m g \\
0.88\end{array}$ & 0.57 & $\begin{array}{r}\mathrm{mg} \\
33.70\end{array}$ & $\begin{array}{r}\% \\
21.90\end{array}$ & $\underline{\mathrm{mg}}$ & $\%$ \\
\hline TI & 1.0583 & 180.8 & 25.28 & 13.96 & 1.66 & 092 & 40.05 & $2: 16$ & 113.2 & 62.64 \\
\hline 平 & & & & 13.69 & & 0.75 & & 22.08 & & 62.64 \\
\hline
\end{tabular}

Animo acid 分析: Amimo acide の分析を $18 \mathrm{~g}$ の試料につを Van Slyke 法尚にて又 $65 \mathrm{~g}$ の陚料

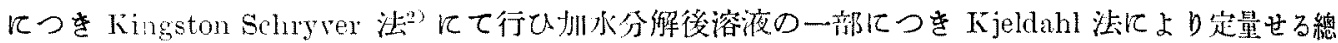

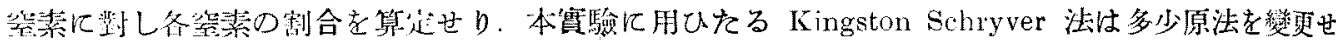

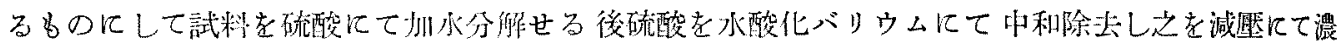

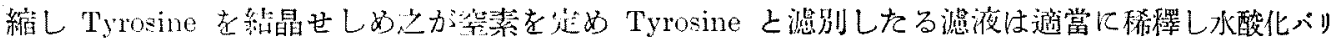

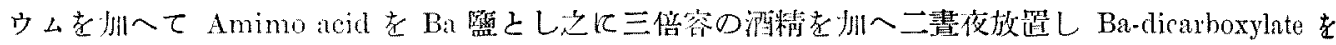

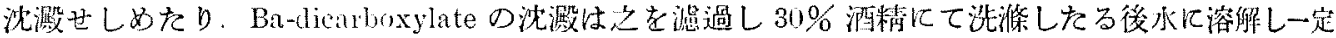

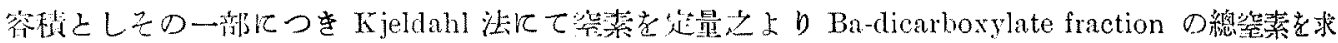
めたり

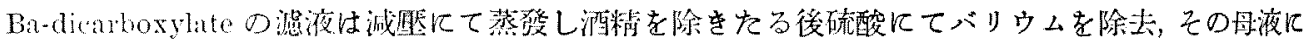
硫酸を㖄へ酸性とし燐タングステン酸にて Diamino acid を沈搌せしめて Monoamino acid と分離せ

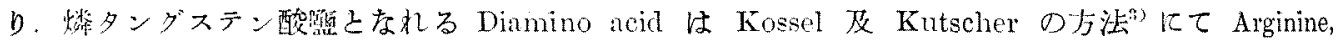
Histidine 及 Lysine t造量せり。

筆五十八柿 Glycinin

\begin{tabular}{|c|c|c|c|c|}
\hline \multirow[b]{2}{*}{ T.X. } & \multicolumn{2}{|c|}{ Van Slyke 法 } & \multicolumn{2}{|c|}{ Kossel-Kutschermg 法 } \\
\hline & $\operatorname{mg}_{292.4}$ & $\%$ & $\begin{array}{r}\text { ing } \\
1070.7\end{array}$ & $\%$ \\
\hline Amide-y & 34.65 & 11.9 & - & - \\
\hline Humin-N & 4.88 & 7.7 & 7.7 & 0.7 \\
\hline Diamino-N T.X. & 70.2 & 24.0 & 259.8 & 24.3 \\
\hline $\mathrm{NH}_{2}-\mathrm{N}$ & 38.1 & - & - & - \\
\hline $\operatorname{Arginin} \cdot N$ & 40.8 & 13.9 & 135.1 & 12.6 \\
\hline Histidine-N & 2.3 & 0.8 & 27.8 & 2.6 \\
\hline Lysin-N & $\ldots 27.1$ & 9.3 & 88.9 & 8.3 \\
\hline Monomnino-X & 181.5 & $6 . .1$ & $515.0^{*}$ & $48.1^{*}$ \\
\hline Dicarboxylit acid-N & - & - & 141.4 & 23.2 \\
\hline Ts rosine-N & 一 & - & 16.4 & 1.5 \\
\hline
\end{tabular}

* Dirarboxylic acid 攻 Tyrosin-N を除く.

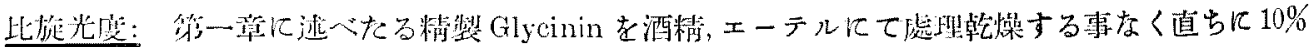

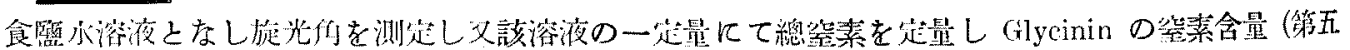
十五主) 上り計算せる係数 5.85 を乘じ溶液の Glycinin 濃度を求め之上り比旋光度を算出せり。

1) 前出. 2) 前出. 3) Hoppe-Syler, Thierfelder：前出, 577 . 


$$
\begin{gathered}
\text { 大豆虽白毁に就 } \\
{[\alpha]_{D}=\frac{-1.72^{\circ} \times 100}{3.38 \times 1}=-51.2^{\circ}}
\end{gathered}
$$

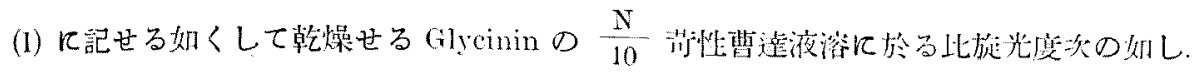

$$
[\alpha]_{\mathrm{D}}=\frac{-2.15^{\circ} \times 100}{3.06 \times 1}=-70.3^{\circ}
$$

3) Glutelin.

\begin{tabular}{|c|c|c|c|c|c|c|c|}
\hline & 試 料 & $\mathrm{CO}_{2}$ & $\mathrm{H}_{2} \mathrm{O}$ & 炏 分 & $C$ & $\mathrm{H}$ & 灰 分 \\
\hline I & $0.2190^{\mathrm{g}}$ & $\cdot 0.4295$ & 0.1423 & $\begin{array}{r}\mathrm{g} \\
0.0007\end{array}$ & $\begin{array}{r}\% \\
53.47\end{array}$ & $\begin{array}{r}\% \\
7.21\end{array}$ & $\begin{array}{r}\% \\
0.33\end{array}$ \\
\hline II & 0.2216 & 0.4342 & 0.1396 & - & 53.43 & 6.99 & - \\
\hline 平 均 & & & & & 53.45 & 7.10 & 0.33 \\
\hline
\end{tabular}

元素分析

符五. 九表 Glutelin

\begin{tabular}{|c|c|c|c|}
\hline & 試 & 登 & 弥 \\
\hline I & $0.191 \frac{9}{\tilde{y}}$ & $\begin{array}{r}\mathrm{mg} \\
29.00\end{array}$ & $\begin{array}{r}\% \\
15.14\end{array}$ \\
\hline Il & 0.116 & 17.56 & 15.10 \\
\hline 平 均 & & & 15.12 \\
\hline
\end{tabular}

總窒素 (Kjeldahl 法)

第 六 十 素 Glutelin

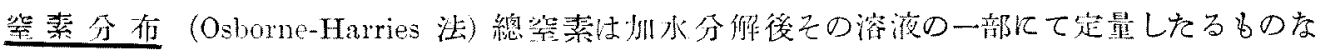

\begin{tabular}{|c|c|c|c|c|c|c|c|c|}
\hline \multirow[b]{2}{*}{ I } & \multirow{2}{*}{$\frac{\text { T.N. }}{\%}$} & \multicolumn{2}{|c|}{ Amide-N } & \multicolumn{2}{|c|}{ Humin-N } & \multicolumn{2}{|c|}{ Diamino-N } & \multirow[t]{3}{*}{ Monoamino-N } \\
\hline & & $\begin{array}{r}\mathrm{mg} \\
18.10\end{array}$ & $\%$ & $\begin{array}{l}\mathrm{mg} \\
6.10\end{array}$ & $\begin{array}{l}\% \\
3.3\end{array}$ & $\begin{array}{l}\mathrm{mg} \\
44.8\end{array}$ & $\begin{array}{r}\% \\
24.1\end{array}$ & \\
\hline II & 186.5 & 17.96 & 8.6 & 8.46 & $4 . \overline{0}$ & 43.3 & 23.3 & \\
\hline 平 均 & & & 9.7 & & 3.9 & & 23.7 & $62.8 \% *$ \\
\hline
\end{tabular}
b.

第六十一表 Glutelin

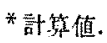

\section{Glycinin に對する過熱水の作用}

1) 反應液 $\mathrm{H}_{3} \mathrm{PO}_{4}, \mathrm{KH}_{2} \mathrm{PO}_{4}, \mathrm{~K}_{\mathrm{gHPO}}$ 及 $\mathrm{KOH}$ の各 $\frac{\mathrm{M}}{10}$ 溶液を作りその混合の割合により種

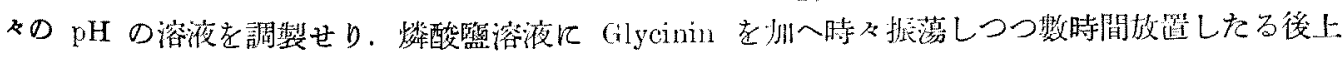
澄液をとりその $\mathrm{pH}$ は水素電極法にて能和監化州里一甘永電板を川ひ電動力 $(\mathrm{E})$ を测定之より算出 せり。 
第 枀十二表

\begin{tabular}{|c|c|c|c|c|c|c|}
\hline & \multicolumn{3}{|c|}{ 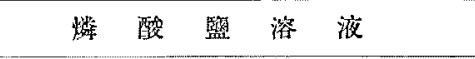 } & \multicolumn{3}{|c|}{ Glycinin+燐酸監溶液 } \\
\hline & $\mathrm{E}$ & 溫 度 & $\mathrm{pH}$ & $\mathbf{E}$ & 溫 度 & $\mathrm{pH}$ \\
\hline 1 & $\begin{array}{l}\mathrm{mv} \\
0.7763\end{array}$ & $31^{\circ}$ & 8.8 & $\mathrm{mv}_{0.7285}$ & $32^{\circ}$ & 8.0 \\
\hline 2 & 0.6563 & $23^{\circ}$ & 7.0 & 0.6418 & $23^{\circ}$ & 6.8 \\
\hline 3 & 0.5179 & $30^{\circ}$ & 4.6 & 0.5454 & $24^{\circ}$ & 5.1 \\
\hline 4 & 0.4033 & $20^{\circ}$ & 2.7 & 0.4689 & $19^{\circ}$ & 3.8 \\
\hline 5 & 0.3765 & $20^{\circ}$ & 2.2 & 0.4619 & $18^{\circ}$ & 3.7 \\
\hline 6 & 0.3667 & $20^{\circ}$ & 2.0 & 0.412 & $19^{\circ}$ & 2.8 \\
\hline 7 & 0.332 & $19^{\circ}$ & 1.4 & 0.346 & $18^{\circ}$ & 1.7 \\
\hline
\end{tabular}

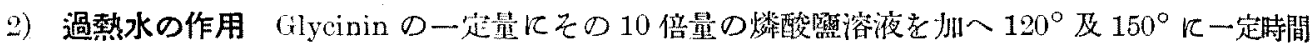

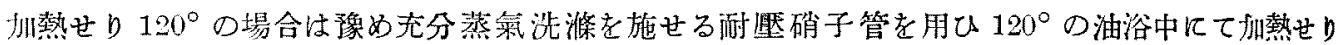

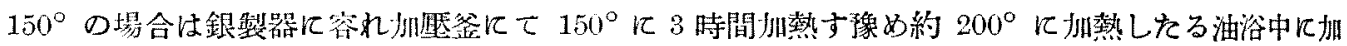

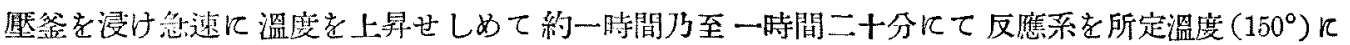
洋せしめ後一定時間該溫度に保てり (油浴溫度 $170 \sim 175^{\circ}$ ).

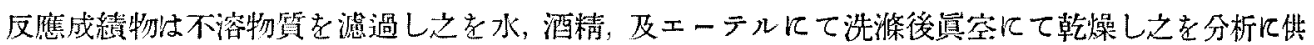
せり，㵂過しその一部にて pH を测定したる後水洗湺液と合し一定容積となしその一部をとり下記 各實驗を行ひたり.

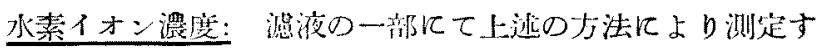

第六十三表＼cjkstart水素イオン濃度

\begin{tabular}{|c|c|c|c|c|c|c|}
\hline \multirow{2}{*}{ 毁驗番號 } & 反 & 供 & $F$ & \multicolumn{3}{|c|}{$\mathrm{pH}$} \\
\hline & 溫 度 & $\mathrm{pH}$ & 時 間 & $\mathrm{E}$ & 溫 度 & $\mathrm{pH}$ \\
\hline 1 & $120^{\circ}$ & 8.0 & 3 & $\begin{array}{r}\mathrm{mv} \\
0.6689\end{array}$ & $28^{\circ}$ & 7.1 \\
\hline 2 & & 8.0 & 6 & 0.6630 & $29^{\circ}$ & 7.0 \\
\hline 3 & & 8.0 & 10 & 0.6551 & $26^{\circ}$ & 6.9 \\
\hline 4 & & 6.7 & 6 & 0.6400 & $19^{\circ}$ & 6.7 \\
\hline 5 & & 5.1 & 6 & 0.5703 & $25^{\circ}$ & 5.5 \\
\hline 6 & & 5.1 & 10 & 0.5761 & $17^{\circ}$ & 5.6 \\
\hline 7 & & 5.1 & 20 & 0.5760 & $26^{\circ}$ & 5.6 \\
\hline 8 & & 3.7 & 6 & 0.5066 & $16^{\circ}$ & 4.4 \\
\hline 9 & & 1.7 & 6 & 0.4350 & $16^{\circ}$ & 3.2 \\
\hline 10 & $150^{\circ}$ & 8.0 & 3 & 0.6442 & $12^{\circ}$ & 6.9 \\
\hline 11 & & 5.1 & 3 & 0.5720 & $9^{\circ}$ & 5.6 \\
\hline 12 & & 1.7 & 3 & 0.4762 & $10^{\circ}$ & 3.9 \\
\hline
\end{tabular}


不溶物質：上述の如く乾燥せる試料につを重量，灰分及總空素を定めたり。

第六十四表不溶物質收量

\begin{tabular}{|c|c|c|c|c|c|c|c|c|}
\hline 潘 號 & 溫 度 & $\mathrm{pH}$ & 時 䦌 & 試 料 & 不 溶 & 物 & 话 牧 & 量 \\
\hline 1 & $120^{\circ}$ & 8.0 & 3 & 10.00 & $\begin{array}{r}\mathrm{g} \\
3.319\end{array}$ & & & $\begin{array}{r}\% \\
33.2\end{array}$ \\
\hline 2 & & 8.0 & 6 & 5.00 & 0.554 & & & 11.1 \\
\hline 3 & & 8.0 & 10 & 5.00 & 0.471 & & & 9.4 \\
\hline 4 & & 6.7 & 6 & 5.00 & 2.169 & & & 43.4 \\
\hline 5 & & 5.1 & 6 & 7.00 & 6.172 & & & 88.2 \\
\hline 6 & & 5.1 & 10 & 21.00 & 18.21 & & & 86.7 \\
\hline 7 & & 5.1 & 20 & 7.00 & 5.617 & & & 80.2 \\
\hline 9 & & 1.7 & 6 & 5.00 & 1.162 & & & 23.2 \\
\hline 11 & $150^{\circ}$ & 5.1 & 3 & 10.0 & 1.110 & & & 11.0 \\
\hline 12 & & 1.7 & 3 & 10.0 & 2.618 & & & 26.2 \\
\hline
\end{tabular}

第六十五瑟不溶物質分析

\begin{tabular}{|c|c|c|c|c|c|c|c|c|c|}
\hline \multirow{2}{*}{ 番號 } & \multicolumn{3}{|c|}{ 反 應 條 件 } & \multicolumn{3}{|c|}{ 總䇪素 (Kjeldahl法) } & \multicolumn{2}{|c|}{ 灰 } & 分 \\
\hline & 㴧 度 & $\mathrm{pH}$ & 間 時 & 試 料 & 笔 & 素 & 馀 粦 & 灰 & 分 \\
\hline 2 & $120^{\circ}$ & 8.0 & 6 & $0.07 \% 5$ & $\begin{array}{r}\mathrm{mg} \\
12.83\end{array}$ & $\begin{array}{r}\% \\
16.6\end{array}$ & 0.3111 & $\begin{array}{l}\mathrm{gm} \\
8.2\end{array}$ & $\begin{array}{r}\% \\
2.6\end{array}$ \\
\hline 4 & & 6.7 & 6 & $\begin{array}{l}0.0878 \\
0.1107\end{array}$ & $\begin{array}{l}14.00 \\
17.87\end{array}$ & $\begin{array}{l}15.9 \\
16.1\end{array}$ & 0.3119 & 6.9 & 2.2 \\
\hline 5 & & 5.1 & 6 & $\begin{array}{l}0.3340 \\
0.1150\end{array}$ & $\begin{array}{l}21.91 \\
19.25\end{array}$ & $\begin{array}{l}16.3 \\
16.7\end{array}$ & 0.5707 & 4.5 & 1.3 \\
\hline 6 & & 5.1 & 10 & $\begin{array}{l}0.1507 \\
0.1636\end{array}$ & $\begin{array}{l}24.60 \\
27.12\end{array}$ & $\begin{array}{l}16.6 \\
16.3\end{array}$ & 0.3378 & 3.0 & 0.9 \\
\hline 7 & & 5.1 & 20 & $\begin{array}{l}0.1402 \\
0.1087\end{array}$ & $\begin{array}{l}23.20 \\
17.74\end{array}$ & $\begin{array}{l}16.6 \\
16.3\end{array}$ & 0.5042 & 5.7 & 1.1 \\
\hline 9 & & 1.7 & 6 & 0.1369 & 19.83 & 14.5 & 0.2752 & 3.3 & 1.3 \\
\hline 11 & $150^{\circ}$ & 5.1 & 3 & 0.1287 & 18.78 & 14.6 & 0.3500 & 22.0 & 6.3 \\
\hline 12 & & 1.7 & 3 & 0.1353 & 19.18 & 14.2 & 0.2778 & 4.4 & 1.6 \\
\hline
\end{tabular}

可溶物質及可溶性穾素：上記溶液の一部をとり湯浴上にて港侵乾固したる後 $105^{\circ}$ に於て恒量之 なるまで乾燥しその重量を求め次にその灰分を定めその装を以て乾燥量とす，可溶性空素は同上の

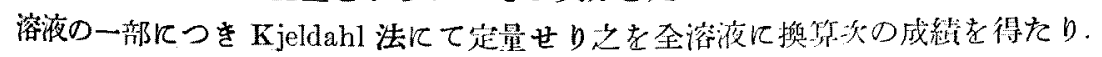


第六十六表可塎物筫

\begin{tabular}{|c|c|c|c|c|c|c|c|c|c|}
\hline \multirow{2}{*}{ 播號 } & \multirow{2}{*}{ 澴 度 } & \multirow{2}{*}{ I HI } & \multirow{2}{*}{ 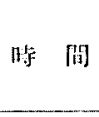 } & \multirow{2}{*}{ 試 料 } & \multicolumn{2}{|c|}{ 可 溶 物 質 } & \multicolumn{3}{|c|}{ 可溶 性 哇 素 } \\
\hline & & & & & & 陚料に對 & & 乾燥量に数 & 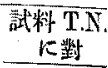 \\
\hline 1 & $120^{\circ}$ & 8.0 & 3 & $10.0^{\mathrm{g}}$ & $\begin{array}{r}g \\
4.554\end{array}$ & $\begin{array}{r}\% \\
45.5\end{array}$ & $\begin{array}{r}\mathrm{gm} \\
794.4\end{array}$ & $\begin{array}{r}\% \\
17.4\end{array}$ & $\begin{array}{r}\% \\
46.4\end{array}$ \\
\hline 2 & & 8.0 & 6 & 5.00 & 3.860 & 77.2 & 786.0 & 17.3 & 78.1 \\
\hline 3 & & 8.0 & 10 & 5.00 & 3.853 & 77.1 & 750.0 & 15.9 & $\pi 1.7$ \\
\hline 4 & & 6.7 & 6 & 5.00 & 2.591 & 51.8 & 410.0 & 15.8 & 47.9 \\
\hline 5 & & 5.1 & 6 & 7.00 & 0.804 & 11.5 & 111.2 & 13.8 & 9.3 \\
\hline 6 & & 5.1 & 10 & 21.0 & 2.823 & 13.4 & 425.7 & 15.1 & 11.8 \\
\hline 7 & & 5.1 & 80 & 7.00 & 1.302 & 18.6 & 207.7 & 15.9 & 17.7 \\
\hline 8 & & 3.7 & 6 & 5.00 & $0.5 \% \overline{0}$ & 11.5 & 88.3 & 10.4 & 10.4 \\
\hline 9 & & 1.7 & 6 & 5.00 & 3.750 & 75.0 & 608.8 & 16.2 & 71.1 \\
\hline 10 & $150^{\circ}$ & 8.0 & 3 & 10.0 & 94.6 & 94.6 & 1562 & 16.5 & 91.3 \\
\hline 11 & & 5.1 & 3 & 10.0 & 84.5 & 84.5 & 1412 & 16.7 & 82.5 \\
\hline 12 & & 1.7 & 3 & 10.0 & 72.4 & 72.4 & 1212 & 16.8 & 70,9 \\
\hline
\end{tabular}

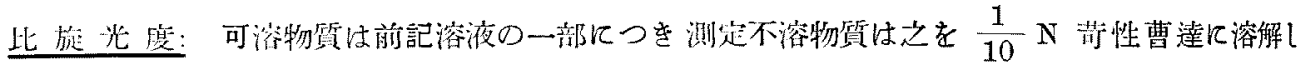
測分せり 。

第六十七衣比旋光庭

\begin{tabular}{|c|c|c|c|c|c|}
\hline \multirow{2}{*}{ 番號 } & \multicolumn{3}{|c|}{ 反 雔 修 件 } & \multicolumn{2}{|c|}{$[\alpha]_{\mathrm{D}}$} \\
\hline & 㬈度 & $\mathrm{pH}$ & 時 閏 & 可溶物 貿 & 不溶物 質 \\
\hline 1 & $120^{\circ}$ & 8.0 & 3 & $\frac{-0.98 \times 100}{2.28 \times 1}=-85.9^{\circ}$ & - \\
\hline 2 & & 8.0 & 6 & $\frac{-0.73 \times 100}{1.93 \times 1}=-75.7^{\circ}$ & $\frac{-0.95 \times 100}{1.23 \times 1}=-77.4^{\circ}$ \\
\hline 3 & & 8.0 & 10 & $\frac{-1.37 \times 100}{3.71 \times 0.5}=-73.9^{\circ}$ & - \\
\hline 4 & & 6.7 & 6 & $\frac{-0.81 \times 100}{2.59 \times 0.5}=-62.5^{\circ}$ & $\frac{-0.40 \times 100}{1.70 \times 1}=-82.4^{\circ}$ \\
\hline$\overline{0}$ & & 5.1 & 6 & $\frac{-0.45 \times 100}{0.80 \times 1}=-56.0^{\circ}$ & $\frac{-1.02 \times 100}{2.43^{\prime} \times 0 . \overline{0}}=-83.9^{\circ}$ \\
\hline 6 & & 5.1 & 10 & $\frac{-0.61 \times 100}{0.94 \times 1}=-64.8^{\circ}$ & $\frac{-1.20 \times 100}{1.6 \times 1}=-65.0^{\circ}$ \\
\hline 7 & & 5.1 & 20 & $\frac{-0.78 \times 100}{1.30 \times 1}=-60.0^{\circ}$ & $\frac{-0.80 \times 100}{1.87 \times 0.5}=-8 \hat{0} .6^{\circ}$ \\
\hline 8 & & 3.7 & 6 & $\frac{-0.34 \times 100}{1.88 \times 1}=-36.2^{\circ}$ & - \\
\hline 9 & & 1.7 & 6 & $\frac{-1.70 \times 100}{1.88 \times 1}=-90.7^{\circ}$ & $\frac{-1.59 \times 100}{1.98 \times 1}=-80.1^{\circ}$ \\
\hline 10 & $150^{\circ}$ & 8.0 & 3 & $\frac{-0.78 \times 100}{3.78 \times 0.5}=-41.3^{\circ}$ & - \\
\hline 11 & & 5.1 & 3 & $\frac{-1.38 \times 100}{3.38 \times 1}=-40.8^{\circ}$ & $\frac{-0.61 \times 100}{1.16 \times 1}=-52.8^{\circ}$ \\
\hline 12 & & 1.7 & 3 & $\frac{-1.39 \times 100}{2.89 \times 1}=-48.1^{\circ}$ & $\frac{-0.40 \times 100}{0.52 \times 1}=-77.5^{\circ}$ \\
\hline
\end{tabular}




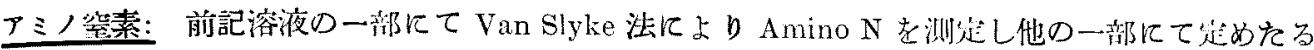
總空素化對し百分率を算出せり。

第六十八表

\begin{tabular}{|c|c|c|c|c|c|c|c|c|}
\hline \multirow{3}{*}{$\begin{array}{c}\text { 番㩆 } \\
\\
1\end{array}$} & \multicolumn{3}{|c|}{ 反應 條 件 } & \multirow{3}{*}{$\begin{array}{r}\text { T.N. } \\
\qquad \begin{array}{r}\mathrm{mg} \\
39.72\end{array}\end{array}$} & \multirow{2}{*}{\multicolumn{2}{|c|}{$\mathrm{N}_{2}$}} & \multirow{2}{*}{\multicolumn{2}{|c|}{ Amino- $N$}} \\
\hline & 溫度 & $\mathrm{pH}$ & 琤 問 & & & & & \\
\hline & $120^{\circ}$ & 8.0 & 3 & & 2.75 & $\left(27^{\circ}, \quad \mathrm{mm}_{757)}\right.$ & $\begin{array}{l}\mathrm{mg} \\
1.53\end{array}$ & $\begin{array}{l}\% \\
3.9\end{array}$ \\
\hline 2 & & 8.0 & 6 & 33.30 & 2.64 & $\left(29^{\circ}, 759\right)$ & 1.45 & 4.4 \\
\hline 3 & & 8.0 & 10 & 29.50 & 1.40 & $\left(22^{\circ}, \quad 761\right)$ & 0.79 & $2 . \pi$ \\
\hline 4 & & 6.7 & 6 & 41.00 & 1.51 & $\left(19^{\circ}, 759\right)$ & 0.86 & 2.1 \\
\hline 5 & & 5.1 & 6 & 22.24 & 1.69 & $\left(25^{\circ}, \quad 761\right)$ & 0.94 & 4.2 \\
\hline 6 & & 5.1 & 10 & 21.29 & 1.94 & $\left(19^{\circ}, 765\right)$ & 1.12 & 5.3 \\
\hline 7 & & 5.1 & 20 & 20.77 & 2.23 & $\left(25^{\circ}, 763\right)$ & 1.24 & 6.0 \\
\hline 9 & & 1.7 & 6 & 80.44 & 2.19 & $\left(10^{\circ}, 763\right)$ & 1.26 & 4.1 \\
\hline 10 & $150^{\circ}$ & 8.0 & 3 & 62.46 & 9.86 & $\left(19^{\circ}, 753\right)$ & 5.60 & 8.9 \\
\hline 11 & & 5.1 & 3 & 56.46 & 7.51 & $\left(19^{\circ}, 762\right)$ & 4.32 & 7.7 \\
\hline 12 & & 1.7 & 3 & 48.46 & 12.17 & $\left(18^{\circ}, 762\right)$ & 6.99 & 14.4 \\
\hline
\end{tabular}

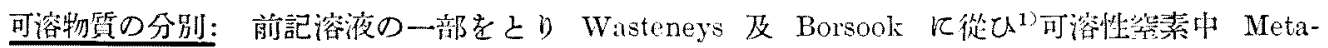

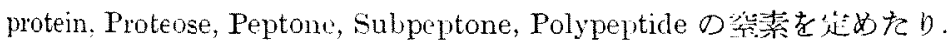

第六十九表

\begin{tabular}{|c|c|c|c|c|c|c|c|c|c|c|c|c|c|c|}
\hline \multirow{2}{*}{ 番號 } & \multicolumn{3}{|c|}{ 反睢條件 } & \multirow{2}{*}{$\frac{\mathrm{T} . \mathrm{N}}{\mathrm{mg}}$} & \multicolumn{2}{|c|}{ Metaprotein $\mathrm{N}$} & \multicolumn{2}{|c|}{ Proteose $N$} & \multicolumn{2}{|c|}{ Peptone N } & \multicolumn{2}{|c|}{$\begin{array}{l}\text { Subpe- } \\
\text { ptone } \mathrm{N}\end{array}$} & \multicolumn{2}{|c|}{ Polypeptide N } \\
\hline & 溫度 & $\mathrm{pH}$ & 時間 & & $\mathrm{nug}$ & $\%$ & $\mathrm{mg}$ & $\%$ & $\mathrm{mg}$ & $\%$ & $\mathrm{mg}$ & $\%$ & $m g$ & $\%$ \\
\hline 1 & $120^{\circ}$ & 8.0 & 3 & 158.9 & 82.9 & 13.6 & 8.6 & 8.6 & & & 13.6 & $8.6^{*}$ & & \\
\hline 2 & & 8.0 & 6 & 139.2 & 101.0 & 75.8 & 19.0 & 14.3 & & & 13.2 & $9.8^{\circ}$ & & \\
\hline 3 & & 8.0 & 10 & 118.0 & 84.2 & 71.4 & 18.9 & 16.0 & & & 14.9 & $12.6^{*}$ & & \\
\hline 4 & & 6.7 & 6 & 164.0 & 126.6 & 77.2 & 19.1 & 11.7 & & & 18.3 & $11.2^{*}$ & & \\
\hline 6 & & 5.1 & 10 & 141.9 & 65.2 & 45.9 & 39.0 & 27.5 & & & 37.7 & $26.6^{*}$ & & \\
\hline 9 & & 1.7 & 6 & 121.8 & 91.56 & 75.2 & 13.4 & 11.0 & & & 16.8 & 13.8 & & \\
\hline 10 & $150^{\circ}$ & 8.0 & 3 & 249.8 & 67.3 & 26.9 & 1,009 & 40.4 & 11.6 & 4.6 & 49.5 & 19.8 & 20.5 & 8.2 \\
\hline 11 & & 5.1 & 3 & 229.3 & 69.5 & 30.2 & 73.0 & 31.8 & 19.6 & 8.5 & 49.6 & 21.6 & 17.6 & 7.7 \\
\hline 12 & & 1.7 & 3 & 242.2 & 27.6 & 36.2 & 67.0 & 39.5 & 31.2 & 16.1 & 42.4 & 21.9 & 35.6 & 18.4 \\
\hline
\end{tabular}

* Peptone, Subpeptone, Polypeptide t合して

1) 前出. 


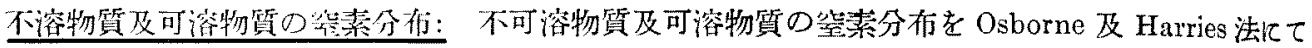
䇥めたり，可溶物質の場合に将前記溶液の他の一定量を加水分解し各種空素を定め之を溶液の他の

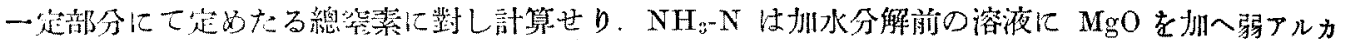
リ性とし蒝溜し溜出する $\mathrm{NH}_{3}$ の学素とす。

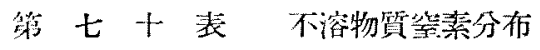

\begin{tabular}{|c|c|c|c|c|c|c|c|c|c|c|c|c|c|}
\hline 番跣 & 温答 & $\mathrm{pH}$ & 時阳 & 試料 & T.N. & \multicolumn{2}{|c|}{ Amide $\mathrm{N}$} & \multicolumn{2}{|c|}{ Humin $N$} & \multicolumn{2}{|c|}{ Diamino $\mathrm{N}$} & \multicolumn{2}{|c|}{ Monoamino N } \\
\hline 2 & $120^{\circ}$ & 8.0 & 6 & $\begin{array}{r}\mathrm{mg} \\
775.0\end{array}$ & $\begin{array}{r}\mathrm{mg} \\
128.3\end{array}$ & $\begin{array}{r}\mathrm{mg} \\
14.74\end{array}$ & 11.5 & $\begin{array}{l}\mathrm{mg} \\
2.18\end{array}$ & $\%$ & $\begin{array}{r}\mathrm{mg} \\
29.20\end{array}$ & $\begin{array}{r}\% \\
22.8\end{array}$ & mg & $\%$ \\
\hline 4 & & 6.7 & 6 & $\begin{array}{r}921.8 \\
1045.0\end{array}$ & $\begin{array}{l}147.9 \\
167.6\end{array}$ & $\begin{array}{l}16.78 \\
18.50\end{array}$ & $\begin{array}{l}11.3 \\
11.0\end{array}$ & $\begin{array}{l}1.94 \\
1.82\end{array}$ & $\begin{array}{l}1.3 \\
1.1\end{array}$ & $\begin{array}{l}33.20 \\
37.50\end{array}$ & $\begin{array}{l}22.5 \\
22.4\end{array}$ & $\begin{array}{r}90.84 \\
102.90\end{array}$ & $\begin{array}{l}61.7 \\
61.4\end{array}$ \\
\hline 5 & & 5.1 & 6 & 973.3 & 160.9 & 20.26 & 12.6 & 2.07 & 1.3 & 38.85 & 24.2 & 101.82 & 63.3 \\
\hline 6 & & 5.1 & 10 & $\begin{array}{l}1030.3 \\
1017.6\end{array}$ & $\begin{array}{l}169.4 \\
167.4\end{array}$ & $\begin{array}{l}21.60 \\
21.57\end{array}$ & $\begin{array}{l}12.7 \\
12.9\end{array}$ & $\begin{array}{l}1.95 \\
1.78\end{array}$ & $\begin{array}{l}1.2 \\
1.1\end{array}$ & $\begin{array}{l}40.72 \\
41.10\end{array}$ & $\begin{array}{l}24.0 \\
24.6\end{array}$ & $\begin{array}{l}103.20 \\
101.95\end{array}$ & $\begin{array}{l}60.9 \\
60.9\end{array}$ \\
\hline 7 & & 5.1 & 20 & 1033.7 & 173.6 & $19.3 \tilde{5}$ & 11.2 & 0.50 & 0.3 & 41.90 & 24.1 & 107.10 & 61.7 \\
\hline 9 & & 1.7 & 6. & $\begin{array}{l}1149.5 \\
1116.8\end{array}$ & $\begin{array}{l}166.4 \\
161.7\end{array}$ & $\begin{array}{l}21.26 \\
20.65\end{array}$ & $\begin{array}{l}12.8 \\
12.8\end{array}$ & $\begin{array}{l}3.35 \\
4.10\end{array}$ & $\begin{array}{l}2.0 \\
2.5\end{array}$ & $\begin{array}{l}37.82 \\
36.00\end{array}$ & $\begin{array}{l}22.7 \\
22.3\end{array}$ & $\begin{array}{r}103.20 \\
-\end{array}$ & $\underset{62.0}{-}$ \\
\hline 11 & $150^{\circ}$ & 5.1 & 3 & $\begin{array}{l}945.0 \\
981.4\end{array}$ & $\begin{array}{l}138.2 \\
143.5\end{array}$ & $\begin{array}{l}7.52 \\
8.35\end{array}$ & $\begin{array}{l}5.4 \\
5.8\end{array}$ & $\begin{array}{l}4.35 \\
4.62\end{array}$ & $\begin{array}{l}3.2 \\
3.2\end{array}$ & $\begin{array}{l}29.60 \\
28.60\end{array}$ & $\begin{array}{l}21.4 \\
19.9\end{array}$ & $\begin{array}{l}93.60 \\
99.48\end{array}$ & $\begin{array}{l}67.7 \\
69.3\end{array}$ \\
\hline 12 & & 1.7 & 3 & 1186.2 & 173.1 & 8.92 & 5.2 & 10.79 & 5.8 & 35.28 & 20.4 & 118.92 & 68.7 \\
\hline
\end{tabular}

第 七十一表 可溶物筫空素分布

\begin{tabular}{|c|c|c|c|c|c|c|c|c|c|c|c|c|}
\hline \multirow{3}{*}{$\begin{array}{c}\text { 潘號 } \\
1 \\
1\end{array}$} & \multicolumn{3}{|c|}{ 反萑條件 } & \multirow{2}{*}{ T.X. } & \multirow{2}{*}{\multicolumn{2}{|c|}{ Amide $\mathrm{N}$}} & \multirow{2}{*}{\multicolumn{2}{|c|}{ Humin $N$}} & \multirow{2}{*}{\multicolumn{2}{|c|}{ Diamino $\mathrm{N}$}} & \multirow{2}{*}{\multicolumn{2}{|c|}{ Monoamino $\mathrm{N}$}} \\
\hline & 溫度 & $\mathrm{pHI}$ & 洔間 & & & & & & & & & \\
\hline & $120^{\circ}$ & 8.0 & 3 & $\begin{array}{r}\mathrm{mg} \\
158.8 \\
158.8\end{array}$ & $\begin{array}{r}\mathrm{mg} \\
22.40 \\
23.30\end{array}$ & $\begin{array}{r}\% \\
14.1 \\
14.0\end{array}$ & $\begin{array}{r}\mathrm{mg} \\
1.63 \\
-\end{array}$ & $\begin{array}{r}\% \\
1.0 \\
\end{array}$ & $\begin{array}{r}\mathrm{gm} \\
31.75 \\
31.85\end{array}$ & $\begin{array}{r}\% \\
20.0 \\
20.1\end{array}$ & $\begin{array}{r}\mathrm{mg} \\
99.30 \\
-\end{array}$ & $\begin{array}{r}\% \\
62.7 \\
-\end{array}$ \\
\hline 2 & & 8.0 & 6 & 133.2 & 18.00 & 13.6 & 0.87 & 0.7 & 28.50 & 21.4 & 85.74 & 63.5 \\
\hline 3 & & 8.0 & 10 & $\begin{array}{l}118.0 \\
118.0\end{array}$ & $\begin{array}{l}18.05 \\
17.92\end{array}$ & $\begin{array}{l}15.3 \\
15.2\end{array}$ & $\begin{array}{l}1.40 \\
1.48\end{array}$ & $\begin{array}{l}1.0 \\
1.0\end{array}$ & $\begin{array}{l}26.20 \\
25.10\end{array}$ & $\begin{array}{l}22.1 \\
21.3\end{array}$ & 74.40 & 63.1 \\
\hline 4 & & 6.7 & 6 & $\begin{array}{l}115.0 \\
115.0\end{array}$ & $\begin{array}{l}19.60 \\
19.60\end{array}$ & $\begin{array}{l}17.0 \\
17.1\end{array}$ & $\begin{array}{l}1.28 \\
1.48\end{array}$ & $\begin{array}{l}1.1 \\
1.3\end{array}$ & $\begin{array}{l}20.13 \\
20.99\end{array}$ & $\begin{array}{l}17.51 \\
18.3\end{array}$ & $72 . \overline{00}$ & $\overline{62.6}$ \\
\hline 6 & & 5.1 & 10 & 141.9 & 29.42 & 20.6 & 2.64 & 1.9 & 33.00 & 23.2 & 78.96 & 55.6 \\
\hline 9 & & 1.7 & 6 & 121.76 & 17.71 & 14.6 & 2.03 & 1.3 & 27.10 & 22.3 & 75.90 & 623 \\
\hline 10 & $150^{\circ}$ & 8.0 & 3 & $\begin{array}{l}156.2 \\
156.2\end{array}$ & $\begin{array}{l}26.30 \\
27.08\end{array}$ & $\begin{array}{l}16.8 \\
17.3\end{array}$ & $\begin{array}{l}2.95 \\
2.82\end{array}$ & $\begin{array}{l}1.9 \\
1.8\end{array}$ & $\begin{array}{l}31.25 \\
31.98\end{array}$ & $\begin{array}{l}20.0 \\
20.5\end{array}$ & $\begin{array}{l}93.90 \\
94.08\end{array}$ & $\begin{array}{l}60.1 \\
60.3\end{array}$ \\
\hline 11 & & 5.1 & 3 & $\begin{array}{l}225.8 \\
225.8\end{array}$ & $\begin{array}{l}38.89 \\
39.02\end{array}$ & $\begin{array}{l}17.2 \\
17.3\end{array}$ & $\begin{array}{l}2.82 \\
2.92\end{array}$ & $\begin{array}{l}1.3 \\
1.3\end{array}$ & $\begin{array}{l}50.70 \\
51.34\end{array}$ & $\begin{array}{l}22.5 \\
22.7\end{array}$ & $\begin{array}{l}133.08 \\
134.88\end{array}$ & $\begin{array}{l}58.9 \\
59.7\end{array}$ \\
\hline 12 & & 1.7 & 3 & $\begin{array}{l}193.8 \\
193.8\end{array}$ & $\begin{array}{l}40.07 \\
40.20\end{array}$ & $\begin{array}{l}20.7 \\
20.7\end{array}$ & $\begin{array}{l}1.84 \\
2.80\end{array}$ & $\begin{array}{l}1.0 \\
1.4\end{array}$ & $\begin{array}{l}40.90 \\
39.35\end{array}$ & $\begin{array}{l}21.1 \\
20.3\end{array}$ & 109.20 & 56.4 \\
\hline
\end{tabular}


第七十二表アンモニア瑟素

\begin{tabular}{|c|c|c|c|c|c|c|}
\hline 番虏 & 罝度 & $\mathrm{pH}$ & 時間 & T.N. & \multicolumn{2}{|c|}{ Ammonia $\mathrm{N}$} \\
\hline 1 & $120^{\circ}$ & 8.0 & 3 & $\begin{array}{r}\mathrm{mg}^{\mathrm{g}} \\
29.72\end{array}$ & $\begin{array}{r}\mathrm{mg} \\
1.85\end{array}$ & $\begin{array}{r}\% \\
4.7\end{array}$ \\
\hline 2 & & 8.0 & 6 & 33.30 & 1.87 & 5.6 \\
\hline 3 & & 8.0 & 10 & 29.50 & 1.60 & 5.4 \\
\hline 4 & & 6.7 & 6 & 36.06 & 2.10 & 5.8 \\
\hline 6 & & 5.1 & 10 & 70.90 & 6.83 & 1.5 \\
\hline 9 & & 1.7 & 6 & 30.44 & 1.30 & 4.3 \\
\hline 10 & $150^{\circ}$ & 8.0 & 3 & 124.92 & 13.20 & 10.6 \\
\hline 11 & & 5.1 & 3 & 112.92 & 17.66 & 15.6 \\
\hline 12 & & 1.7 & 3 & 96.92 & 16.03 & 16.5 \\
\hline
\end{tabular}

3) Metaprotein, Proteose 及 Peptone 窒素分布 前記 (2) 亿於当ると同核の條件沉於て Glycinin

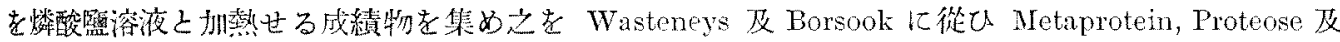

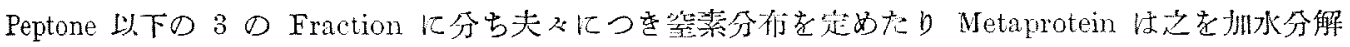

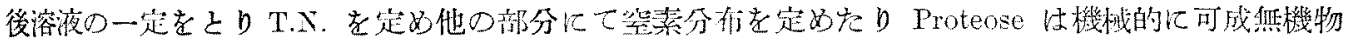

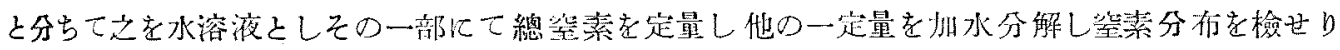

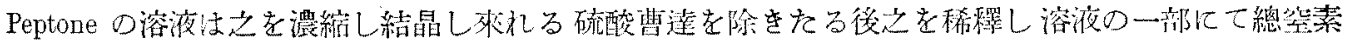
を他の部分にて䇪素分布を定量せり $\mathrm{NH}_{3}-\mathrm{N}$ は Proteose 或は Peptone 溶液につをその一定量をりを

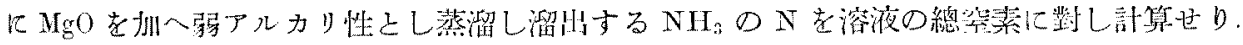

籍七十三表 空素分们

\begin{tabular}{|c|c|c|c|c|c|c|c|c|c|c|c|}
\hline 菜號 & 反漹绦件 & Fractions & T.N. & \multicolumn{2}{|c|}{ Amide $\mathrm{N}$} & \multicolumn{2}{|c|}{ Humm $N$} & \multicolumn{2}{|c|}{ Diamino $\mathrm{N}$} & \multicolumn{2}{|c|}{ Monoamino $\mathrm{N}$} \\
\hline \multirow{3}{*}{13} & $120^{\circ}$ & Metaprotein & $\left\{\begin{array}{r}\mathrm{mg} \\
122.2 \\
122.2\end{array}\right.$ & $\begin{array}{r}\mathrm{mg} \\
13.70 \\
13.62\end{array}$ & $\begin{array}{r}\% \\
11.2 \\
11.2\end{array}$ & $\begin{array}{l}\operatorname{mg} \\
2.25 \\
2.50\end{array}$ & $\begin{array}{l}\% \\
1.8 \\
2.1\end{array}$ & $\begin{array}{r}\mathrm{mg} \\
26.18 \\
27.00\end{array}$ & $\begin{array}{r}\% \\
21.4 \\
22.5\end{array}$ & $\begin{array}{r}\text { ng } \\
80.04 \\
80.88\end{array}$ & $\begin{array}{r}\% \\
65.5 \\
66.2\end{array}$ \\
\hline & $\mathrm{pH}=8.0$ & Proteose & $\left\{\begin{array}{l}116.8 \\
116.8\end{array}\right.$ & $\begin{array}{l}15.38 \\
15.18\end{array}$ & $\begin{array}{l}13.2 \\
13.1\end{array}$ & $\overline{1.01}$ & $\overrightarrow{0.9}$ & $\begin{array}{l}28.43 \\
28.40\end{array}$ & $\begin{array}{l}24.5 \\
24.4\end{array}$ & $\begin{array}{l}67.50 \\
68.82\end{array}$ & $\begin{array}{l}58.1 \\
59.3\end{array}$ \\
\hline & 6 侍間 & Peptone & $\begin{array}{l}91.8 \\
91.8\end{array}$ & $\begin{array}{l}51.45 \\
51.72\end{array}$ & $\begin{array}{l}56.1 \\
56.3\end{array}$ & $\begin{array}{l}0.53 \\
0.82\end{array}$ & $\begin{array}{l}0.6 \\
0.9\end{array}$ & $\begin{array}{l}5.90 \\
6.41\end{array}$ & $\begin{array}{l}6.4 \\
7.0\end{array}$ & $\begin{array}{l}30.87 \\
31.29\end{array}$ & $\begin{array}{l}34.0 \\
34.1\end{array}$ \\
\hline \multirow{3}{*}{14} & $120^{\circ}$ & Metaprotein & $\begin{array}{l}147.2 \\
147.2\end{array}$ & $\begin{array}{l}16.30 \\
16.38\end{array}$ & $\begin{array}{l}11.1 \\
11.1\end{array}$ & $\begin{array}{l}7.40 \\
7.95\end{array}$ & $\begin{array}{l}5.0 \\
5.4\end{array}$ & $\begin{array}{l}30.08 \\
28.70\end{array}$ & $\begin{array}{l}20.4 \\
19.5\end{array}$ & $\begin{array}{l}87.50 \\
92.58\end{array}$ & $\begin{array}{l}59.7 \\
62.2\end{array}$ \\
\hline & $\mathrm{pH}=5.1$ & Proteose & 166.9 & 22.65 & 13.6 & 6.54 & 3.9 & 38.05 & 22.8 & 102.24 & 61.3 \\
\hline & 10 時閑 & Peptone & 222.6 & 101.60 & 48.3 & 1.80 & 0.8 & 11.06 & 4.97 & 103.32 & 46.4 \\
\hline \multirow{3}{*}{15} & $120^{\circ}$ & Metaprotein & 85.0 & 10.45 & 12.3 & 2.00 & 2.4 & 18.36 & 21.6 & 53.16 & 62.5 \\
\hline & $\mathrm{pH}=1 . \bar{t}$ & Proteose & $\begin{array}{l}191.5 \\
191.5\end{array}$ & $\begin{array}{l}16.84 \\
16.92\end{array}$ & $\begin{array}{l}8.8 \\
6.8\end{array}$ & $\begin{array}{l}1.40 \\
1.68\end{array}$ & $\begin{array}{l}0.7 \\
0.9\end{array}$ & $\begin{array}{l}50.20 \\
63.28\end{array}$ & $\begin{array}{l}30.9 \\
33.0\end{array}$ & $\begin{array}{l}112.80 \\
107.16\end{array}$ & $\begin{array}{l}58.9 \\
56.0\end{array}$ \\
\hline & 6 洔閏 & Peptone & 149.0 & $63.66^{\circ}$ & 42.7 & 1.84 & 1.2 & 15.98 & 10.7 & 64.26 & 43.1 \\
\hline
\end{tabular}


第七十四表学素分布

\begin{tabular}{|c|c|c|c|c|c|c|c|c|c|c|c|}
\hline 乘號 & 反照修件 & Fraction & T.N. & \multicolumn{2}{|c|}{ Amide $\mathrm{N}$} & \multicolumn{2}{|c|}{ Humin $N$} & \multicolumn{2}{|c|}{ Diamino $\mathrm{N}$} & \multicolumn{2}{|c|}{ Monoamino $\mathrm{N}$} \\
\hline \multirow{3}{*}{16} & $150^{\circ}$ & Metaprotein & $\left\{\begin{array}{r}\mathrm{mg} \\
184.9 \\
184.9\end{array}\right.$ & $\begin{array}{l}\mathrm{mg} \\
11.75 \\
11.79\end{array}$ & $\begin{array}{l}\% \\
6.4 \\
6.4\end{array}$ & $\begin{array}{l}\mathrm{mg} \\
6.30 \\
5.98\end{array}$ & $\begin{array}{l}\% \\
3.4 \\
3.2\end{array}$ & $\begin{array}{r}\mathrm{mg} \\
41.35 \\
41.48\end{array}$ & $\begin{array}{r}\% \\
22.4 \\
22.4\end{array}$ & $\begin{array}{r}\mathrm{mg} \\
121.86 \\
123.00\end{array}$ & $\begin{array}{r}\% \\
65.9 \\
66.5\end{array}$ \\
\hline & $\mathrm{pH}=8.1$ & Proteose & $\left\{\begin{array}{l}156.3 \\
156.3\end{array}\right.$ & $\begin{array}{l}14.56 \\
14.68\end{array}$ & $\begin{array}{l}9.3 \\
9.4\end{array}$ & $\begin{array}{l}2.18 \\
2.26\end{array}$ & $\begin{array}{l}1.4 \\
1.5\end{array}$ & $\begin{array}{l}41.20 \\
43.10\end{array}$ & $\begin{array}{l}26.4 \\
27.6\end{array}$ & $\begin{array}{l}102.60 \\
103.98\end{array}$ & $\begin{array}{l}64.6 \\
665\end{array}$ \\
\hline & 2 洔閐 & Peptone & 165.3 & 55.89 & 33.8 & 3.00 & 1.8 & 18.40 & 11.1 & 83.83 & 50.7 \\
\hline \multirow{3}{*}{17} & $150^{\circ}$ & Metaprotein & $\left\{\begin{array}{l}160.6 \\
160.6\end{array}\right.$ & $\begin{array}{l}10.11 \\
10.08\end{array}$ & $\begin{array}{l}6.3 \\
6.3\end{array}$ & $\begin{array}{l}4.82 \\
4.98\end{array}$ & $\begin{array}{l}2.7 \\
3.1\end{array}$ & $\begin{array}{l}37.80 \\
37.28\end{array}$ & $\begin{array}{l}23.5 \\
23.2\end{array}$ & $\begin{array}{l}106.65 \\
108.48\end{array}$ & $\begin{array}{l}66.4 \\
67.6\end{array}$ \\
\hline & $p H=5.1$ & Proteose & $\left\{\begin{array}{l}120.0 \\
120.0\end{array}\right.$ & $\begin{array}{l}10.20 \\
10.16\end{array}$ & $\begin{array}{l}8.3 \\
8.5\end{array}$ & $\begin{array}{l}1.82 \\
2.00\end{array}$ & $\begin{array}{l}1.5 \\
1.7\end{array}$ & $\begin{array}{l}29.90 \\
28.70\end{array}$ & $\begin{array}{l}24.9 \\
23.9\end{array}$ & 77.08 & $\begin{array}{r}64.7 \\
-\end{array}$ \\
\hline & 3 眐绩 & Peptone & $\begin{array}{l}1: 34.3 \\
134.9\end{array}$ & $\begin{array}{l}49.50 \\
49.25\end{array}$ & $\begin{array}{l}36.9 \\
36.7\end{array}$ & $\begin{array}{l}1.74 \\
1.20\end{array}$ & $\begin{array}{l}1.3 \\
0.9\end{array}$ & $\begin{array}{l}17.12 \\
17.85\end{array}$ & $\begin{array}{l}12.8 \\
13.3\end{array}$ & $\begin{array}{l}66.72 \\
63.80\end{array}$ & $\begin{array}{l}49.7 \\
47.6\end{array}$ \\
\hline \multirow{3}{*}{18} & $150^{\circ}$ & Metiprotein & 81.7 & $5.70^{\prime}$ & 7.0 & 3.80 & 4.6 & 16.22 & 19.9 & 55.20 & 67.56 \\
\hline & $\mathrm{pH}=1.7$ & Proteose & $\left\{\begin{array}{l}170.1 \\
170.1\end{array}\right.$ & $\begin{array}{l}10.70 \\
10.94\end{array}$ & $\begin{array}{l}6.3 \\
6.4\end{array}$ & $\begin{array}{l}9.42 \\
2.75\end{array}$ & $\begin{array}{l}1.4 \\
1.6\end{array}$ & $\begin{array}{l}48.45 \\
48.40\end{array}$ & $\begin{array}{l}28.5 \\
28.5\end{array}$ & $\begin{array}{l}108.24 \\
107.70\end{array}$ & $\begin{array}{l}63.6 \\
63.3\end{array}$ \\
\hline & 3 時間 & Peptone & $\left\{\begin{array}{l}150.3 \\
150.3\end{array}\right.$ & $\begin{array}{l}62.80 \\
62.98\end{array}$ & $\begin{array}{l}41.8 \\
42.0\end{array}$ & $\begin{array}{l}1.60 \\
1.66\end{array}$ & $\begin{array}{l}1.1 \\
1.1\end{array}$ & $\begin{array}{l}18.32 \\
18.64\end{array}$ & $\begin{array}{l}12.2 \\
12.4\end{array}$ & $\begin{array}{l}70.80 \\
69.12\end{array}$ & $\begin{array}{l}47.1 \\
46.0\end{array}$ \\
\hline
\end{tabular}

第七十五表 アンモニア䇺素

\begin{tabular}{|c|c|c|c|c|c|c|c|}
\hline 潘躆 & 㵋度 & $\mathrm{pH}$ & 時 閒 & Fraction & T.N. & \multicolumn{2}{|c|}{ Ammonia $\mathrm{N}$} \\
\hline \multirow{2}{*}{13} & \multirow{6}{*}{$120^{\circ}$} & \multirow{2}{*}{8.0} & \multirow{2}{*}{6} & Proteose & $\begin{array}{r}\mathrm{mg} \\
46.80\end{array}$ & $\begin{array}{l}\mathrm{m} g \\
0.30\end{array}$ & $\begin{array}{r}\% \\
0.75\end{array}$ \\
\hline & & & & Peptone & 16.32 & 4.98 & 30.5 \\
\hline \multirow{2}{*}{14} & & \multirow{2}{*}{5.1} & \multirow{2}{*}{10} & Proteose & 122.94 & 2.76 & 2.2 \\
\hline & & & & Peptone & 73.38 & 29.45 & 41.4 \\
\hline \multirow{2}{*}{15} & & \multirow{2}{*}{1.7} & \multirow{2}{*}{6} & Proteose & 76.60 & 0.08 & 0.1 \\
\hline & & & & Peptone & 29.80 & 12.09 & 40.6 \\
\hline 16 & $150^{\circ}$ & 8.0 & 3 & Peptone & 66.12 & 18.48 & 27.9 \\
\hline \multirow{2}{*}{17} & & \multirow{2}{*}{5.1} & \multirow{2}{*}{3} & Proteose & 60.6 & 1.21 & 2.0 \\
\hline & & & & Peptone & 53.72 & 16.70 & 31.1 \\
\hline \multirow{2}{*}{18} & & \multirow{2}{*}{1.7} & \multirow{2}{*}{3} & Proteose & 85.05 & 0.8 & 0.9 \\
\hline & & & & Peptone & 75.16 & 30.92 & 41.1 \\
\hline
\end{tabular}

4）分解生成物のアミノ酸 $\mathrm{pH}=2$ 及 8 にて Glycinin t $150^{\circ}$ 亿 3 㭙間州熱し成續物支上述の 如く不溶物项，Metaprotein, Proteose, Peptone (Polypeptide t合む) に分别L Glycinin の場合之同㥞

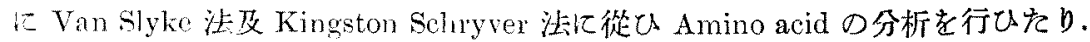


第七十六裴 Van Slyke 法化々る分析

\begin{tabular}{|c|c|c|c|c|c|}
\hline \multirow{2}{*}{$\frac{\mathrm{pH}}{\text { Fraction }}$} & \multicolumn{2}{|c|}{ 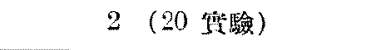 } & \multicolumn{3}{|c|}{8 (茫瞼 20) } \\
\hline & Insol. sub. & Proteose & Metaprotein & Proteose & Peptone \\
\hline T.N. & $\begin{array}{c}\mathrm{mg} \\
534.4\end{array}$ & $\begin{array}{l}\mathrm{mgg} \\
380.0\end{array}$ & $\begin{array}{l}\mathrm{mg} \\
276.9\end{array}$ & $\begin{array}{l}m g \\
227.8\end{array}$ & $\begin{aligned} \mathrm{mg} \\
454.4\end{aligned}$ \\
\hline Amide $\mathrm{N}$ & 28.72 & 25.90 & 16.22 & 16.42 & 195.9 \\
\hline Humin $\mathrm{N}$ & 16.73 & 3.70 & 6.58 & 5.10 & - \\
\hline \multicolumn{6}{|l|}{ Diamino $N$} \\
\hline T.N. & 123.4 & 113.7 & 62.2 & 58.4 & 44.2 \\
\hline $\mathrm{NH}_{2}-\mathrm{N}$ & 68.5 & 63.4 & 35.3 & 31.8 & 28.6 \\
\hline Arginine $N$ & 69.1 & 64.2 & 36.3 & 32.8 & 15.8 \\
\hline Histidine $\mathrm{N}$ & 4.5 & 3.2 & 0.4 & 3.0 & 5.6 \\
\hline Lysine $\mathrm{N}$ & 49.7 & 46.3 & 25.4 & 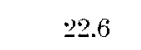 & 22.8 \\
\hline Monoamino $\mathrm{N}$ & 347.1 & 9320 & 191.1 & 147.6 & 214.6 \\
\hline Amide $\mathrm{X}$ & 5.4 & 6.8 & 5.9 & 7.2 & $\begin{array}{r}\% \\
43.1\end{array}$ \\
\hline Humin $\mathrm{N}$ & 3.1 & 1.0 & 2.4 & 2.2 & - \\
\hline Diamino $\mathrm{N}$ & 23.1 & 29.9 & 22.5 & 25.6 & 9.7 \\
\hline Arginine $N$ & 13.0 & 16.9 & 13.1 & 144 & 3.5 \\
\hline Histidien $N$ & 0.8 & 0.8 & 0.2 & 1.3 & 1.2 \\
\hline Lysine $\mathrm{N}$ & 9.3 & 12.2 & 9.2 & 9.9 & 5.0 \\
\hline Monoamino $\mathrm{N}$ & 65.0 & 61.1 & 69.0 & 64.8 & 47.2 \\
\hline
\end{tabular}

第七十七琵 Kingston Schryver 分析

\begin{tabular}{|c|c|c|c|c|}
\hline \multirow{2}{*}{$\frac{\mathrm{pH}}{\text { Fraction }}$} & \multicolumn{2}{|c|}{ 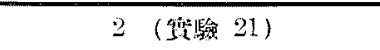 } & \multicolumn{2}{|c|}{ 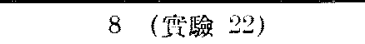 } \\
\hline & Proteose & Peptone & Proteose & Peptone \\
\hline T.N. & $\begin{array}{r}m g \\
2788.0\end{array}$ & $\begin{array}{r}\mathrm{mg} \\
2553.0\end{array}$ & $\begin{array}{r}\mathrm{mg} \\
1984.0\end{array}$ & $\begin{array}{r}\mathrm{mg} \\
1560.6\end{array}$ \\
\hline Amide $\mathrm{N}$ & - & 973.1 & 128.1 & 245.8 \\
\hline Humin $N$ & 7.3 & - & 6.1 & 4.7 \\
\hline Dicarboxylic acid $\mathrm{N}$ & 168.0 & 159.0 & 158.3 & 79.7 \\
\hline Tyrosine $\mathrm{N}$ & 25.1 & 0.6 & 30.5 & 1.1 \\
\hline Diamino $\mathrm{N}$ & 860.5 & 241.3 & 506.0 & 280.0 \\
\hline Arginine 2 & 375.2 & 75.8 & 230.0 & 101 \\
\hline Histidine $\mathrm{N}$ & 72.7 & 41.1 & 58.5 & 37.3 \\
\hline Lysine N & 241.3 & 99.1 & 205.0 & - \\
\hline Monoamino $\mathrm{N}$ & 1432.5 & 959 & 1070 & 624.5 \\
\hline Amide $N$ & $\%$ & $\begin{array}{r}\% / n \\
38.1\end{array}$ & $\%$ & $\begin{array}{r}\% \\
3 \%\end{array}$ \\
\hline Humin $\mathrm{X}$ & 0.3 & - & 0.3 & 0.3 \\
\hline Dicarboxylic acid $N$ & 6.0 & 6.2 & 7.9 & 5.1 \\
\hline Tyrosine $\mathrm{N}$ & 0.9 & 0.0 & 1.5 & 0.1 \\
\hline Diamino $N$ & 30.9 & 9.5 & 25.5 & 17.9 \\
\hline Arginine $\mathrm{N}$ & 13.5 & 3.0 & 11.6 & $6 . \tilde{0}$ \\
\hline Histidine $\mathrm{N}$ & 3.0 & 1.6 & 2.9 & 2.4 \\
\hline Lysine $\mathrm{N}$ & 8.0 & 3.9 & 10.5 & $9.0^{*}$ \\
\hline Monoamino $\mathrm{N}^{* *}$ & 51.4 & 37.5 & 52.8 & 40.7 \\
\hline
\end{tabular}

* Diamino $\mathrm{N}$-(Arginine $\mathrm{N}+$ Histidine N) として計算.

** Dicarboxylic aeid N 及 Tyrosine $\mathrm{N}$ を除々。 


\section{Metaprotein 及 Proteose に對する過熱水の作用}

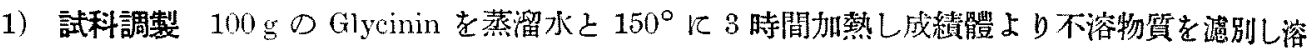

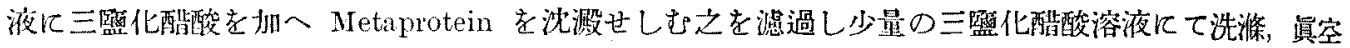

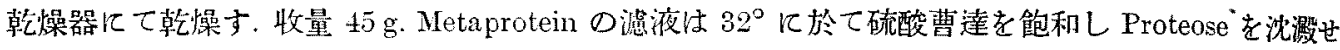
しめ上澄液を倾斜し去り沈澱は之を水に溶解し同上の力法により硫酸曹達にて再沈澱せしめ之を道 に水に溶解し $100 \mathrm{cc}$ とす その一部をとり乾燥量, 灰分, 總辢素及䇪素分布を定め他の一部にて過 蓺水の作用を貫驗せり。

第七十八表

\begin{tabular}{|c|c|c|c|}
\hline & & Metaprotein & Proteose \\
\hline \multirow[b]{2}{*}{ 總 永素 } & 試粦 & $0.1061 \mathrm{~g}$ & $0.0811 \mathrm{~g}$ \\
\hline & T.X. & $\begin{array}{l}13.98 \mathrm{mg} \\
13 .: \%\end{array}$ & $\begin{array}{l}12.24 \mathrm{mg} \\
15.9 \%\end{array}$ \\
\hline \multirow{3}{*}{ } & T.S. & $26.4 \mathrm{mg}$ & $24.5 \mathrm{mg}$ \\
\hline & $\mathrm{N}_{2}$ & $\begin{array}{c}1.8 \mathrm{cc} \\
\left(20^{\circ}, \quad 761 \mathrm{~mm}\right)\end{array}$ & $\begin{array}{c}2.8 \mathrm{cc} \\
\left(29^{\circ}, 757 \mathrm{~mm}\right)\end{array}$ \\
\hline & $\mathrm{NH}_{z-\mathrm{N}}$ & $\begin{array}{l}0.79 \mathrm{mg} \\
3.0 \%\end{array}$ & $\begin{array}{l}1.51 \mathrm{mg} \\
6.2 \%\end{array}$ \\
\hline
\end{tabular}

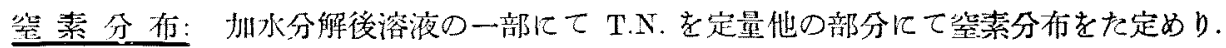

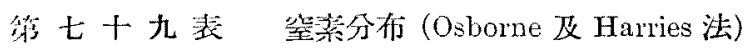

\begin{tabular}{|c|c|c|c|c|}
\hline \multirow[b]{2}{*}{ T.X. } & \multicolumn{2}{|c|}{ Metaprotein } & \multicolumn{2}{|c|}{ Proteose } \\
\hline & $\underset{136.1}{\mathrm{mg}}$ & $\%$ & $\underset{146.9}{\mathrm{mg}}$ & $\%$ \\
\hline Amide $X$ & 9.68 & 7.1 & 12.72 & 8.7 \\
\hline Humin $\mathrm{N}$ & 2.28 & 1.7 & 1.99 & 1.4 \\
\hline Diamino $N$ & 28.90 & 21.2 & 36.68 & 25.0 \\
\hline Monoanino $\mathrm{X}$ & 95.9 & 70.5 & 89.2 & 60.8 \\
\hline
\end{tabular}

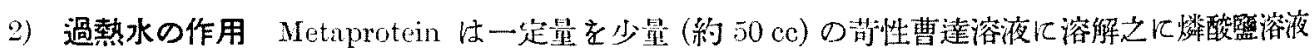

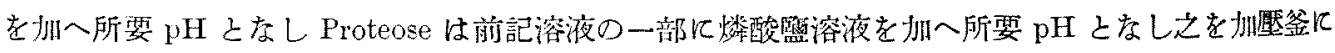
て加熱せ り試料㵋度は Metaprotein の場合 6〜7\%, Proteose の場合 3〜4\%なり反應成縝の處理分 析法は Glycinin の場合と同樣とす即ち不溶物質を滤過し水，酒精，エーテルにて洗湺し真空影器器

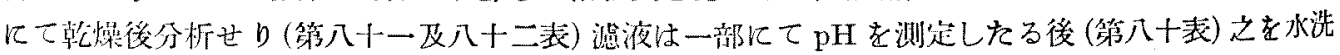
滌液と合し一定容積としその中の一定量をとり夫々可溶物質乾燥量, 總空素 (第八十一表) アミ)等

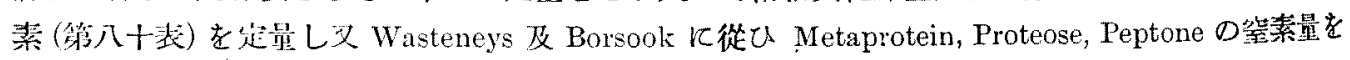
定めたり (第八十三表) 又不溶物質，可溶物質，及可溶物質中各 Fraction の空素分布を Osborne 及 Harries に從ひ定量せり (第八十四表) 不溶物質及各 Fractionの總器素は加水分解後溶液の一部につ

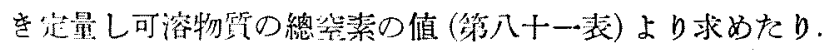




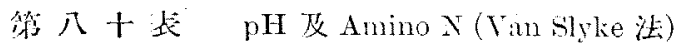

\begin{tabular}{|c|c|c|c|c|c|c|c|c|c|c|c|}
\hline \multirow{2}{*}{ 試料 } & \multirow{2}{*}{ 番㩆 } & \multirow{2}{*}{$\mathrm{pH}$} & \multicolumn{3}{|c|}{ 反盟成縝物 $\mathrm{pH}$} & \multicolumn{6}{|c|}{ Amino $\mathrm{N}$} \\
\hline & & & \multirow{2}{*}{$\frac{\mathrm{E}}{\mathrm{mg}}$} & \multirow{2}{*}{$\frac{\text { 溫慗 }}{23^{\circ}}$} & \multirow{2}{*}{$\frac{\mathrm{pH}}{6.4}$} & \multirow{2}{*}{$\begin{array}{r}\text { T.N. } \\
\begin{aligned} \\
25.14\end{aligned}\end{array}$} & \multicolumn{3}{|c|}{$\mathrm{N}$} & \multicolumn{2}{|c|}{ Amino $\mathrm{N}$} \\
\hline 象 & 23 & 8.0 & & & & & $\begin{array}{r}c e \\
4.8\end{array}$ & $\left(2 r^{\circ}\right)$ & $\min _{762)}$ & $\begin{array}{r}m g \\
2.64\end{array}$ & $\begin{array}{r}\% \\
10.5\end{array}$ \\
\hline 迹: & 24 & 5.1 & 0.4685 & $21^{\circ}$ & 3.8 & 19.32 & 4.9 & $\left(2^{-}{ }^{\circ}\right.$, & $762)$ & 2.65 & 13.6 \\
\hline$\sum_{i}^{2}$ & 25 & 2.0 & 0.3958 & $22^{\circ}$ & 2.6 & 20.44 & 7.6 & $\left(24^{\circ}\right.$, & $764)$ & 2.37 & 20.8 \\
\hline \multirow{3}{*}{$\begin{array}{l}0 \\
0 \\
0 \\
0 \\
0 \\
0 \\
0\end{array}$} & 26 & 8.4 & 0.6252 & $24^{\circ}$ & 6.5 & 15.22 & 43 & $\left(26^{\circ}\right.$ & $758)$ & 2.37 & 15.5 \\
\hline & $2 \pi$ & 4.8 & 0.5460 & $25^{\circ}$ & 5.1 & 15.60 & 4.3 & $\left(29^{\circ}\right.$ & $760)$ & 1.90 & 12.2 \\
\hline & 28 & 1.8 & 0.3964 & $25^{\circ}$ & 2.6 & 1203 & 5.4 & $\left(27^{\circ}\right.$ & $756)$ & 2.95 & 34.5 \\
\hline
\end{tabular}

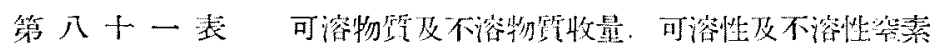

\begin{tabular}{|c|c|c|c|c|c|c|c|c|c|c|}
\hline 試料 & 要號 & $\mathrm{pH}$ & 武料 & 試料總管素 & 川溶物佸 & 不溶物得 & \multicolumn{2}{|c|}{ 叮溶性等素 } & \multicolumn{2}{|c|}{ 不溶性䇪素 } \\
\hline \multirow{3}{*}{ 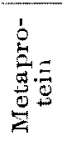 } & 23 & 8.0 & 10.0 & $\begin{array}{r}\mathrm{mg} \\
1317\end{array}$ & $9.0 \stackrel{\underline{x}}{1}$ & $\underline{g}$ & $\begin{array}{r}n g \\
1257 \\
1257\end{array}$ & 95.4 & $\begin{array}{r}\mathrm{mg} \\
63.4\end{array}$ & $\begin{array}{r}\mathrm{g} \\
\times \\
.8\end{array}$ \\
\hline & 24 & 5.1 & 10.0 & 1317 & 7.38 & 1.82 & 966 & 73.4 & 245.8 & 18.6 \\
\hline & 25 & 2.0 & 10.0 & 1317 & 7.83 & 1.69 & 1022 & 73.6 & 208.5 & 15.4 \\
\hline \multirow{3}{*}{ 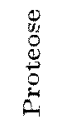 } & 26 & 8.4 & 4.06 & 612 & 3.83 & - & 609 & 49.5 & 8.3 & 0.5 \\
\hline & 27 & 4.8 & 4.06 & 612 & - & - & 624 & 102 & 3.8 & 0.6 \\
\hline & 28 & 1.8 & 3.24 & 490 & 3.56 & - & 481 & 98.2 & 5.8 & 1.2 \\
\hline
\end{tabular}

第八十二表 Netaprotein より生成せる不溶物質

\begin{tabular}{|c|c|c|c|c|}
\hline 番號 & $\mathrm{pH}$ & 試 & & \\
\hline \multirow{3}{*}{24} & \multirow{3}{*}{5.1} & $\frac{g}{0.1425}$ & $\begin{array}{r}\mathrm{mg} \\
19.28\end{array}$ & $\begin{array}{r}\% \\
13.53\end{array}$ \\
\hline & & 0.1074 & 14.24 & 13.24 \\
\hline & & 0.0973 & 13.23 & 13.60 \\
\hline \multirow{3}{*}{25} & \multirow{3}{*}{2.0} & 0.1041 & 12.37 & 11.88 \\
\hline & & 0.1660 & 20.20 & 12.17 \\
\hline & & 0.1583 & 19.18 & ]. 2.12 \\
\hline
\end{tabular}

第八十三表 可泬物筫分別 (Westeneys 及 Borsook 法)

\begin{tabular}{|c|c|c|c|c|c|c|c|c|c|}
\hline 試料 & 藩號 & $\mathrm{pH}$ & T.N. & \multicolumn{2}{|c|}{ Metaprotein $\mathrm{N}$} & \multicolumn{2}{|c|}{ Proteose N } & \multicolumn{2}{|c|}{ Peptone N } \\
\hline \multirow{3}{*}{ 总 } & 23 & 8.0 & 100.6 & $\begin{array}{l}\mathrm{mg} \\
37.0\end{array}$ & $\begin{array}{r}\% \\
36.8\end{array}$ & $\begin{array}{l}\operatorname{mg} \\
32.7\end{array}$ & $\begin{array}{r}\% \\
32.5\end{array}$ & $\begin{array}{l}\operatorname{mg} \\
30.9\end{array}$ & $\begin{array}{r}\% \\
30.7\end{array}$ \\
\hline & 24 & 5.1 & 77.3 & 8.3 & 10.7 & 29.3 & 37.9 & 39.7 & 51.4 \\
\hline & 25 & 2.0 & 81.8 & 4.0 & 4.9 & 38.8 & 47.4 & 390 & 47.7 \\
\hline \multirow{3}{*}{ 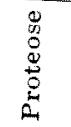 } & 26 & 8.4 & 60.9 & 1.0 & 1.6 & 524 & 86.0 & 7.45 & 12.4 \\
\hline & 27 & 4.8 & 62.4 & 2.3 & 3.7 & 35.9 & 57.5 & 24.2 & 38.8 \\
\hline & 28 & 1.8 & 48.1 & 0 & 0 & 20.6 & 43.8 & 27.5 & 56.2 \\
\hline
\end{tabular}


第八十四婊 空素分布

\begin{tabular}{|c|c|c|c|c|c|c|c|c|c|c|c|c|}
\hline 試料 & 潘跟 & $\mathrm{pH}$ & Fraction & T.N. & Amid & & Humi & & Diami & $\circ \mathrm{N}$ & Monoan & $10 \mathrm{~N}$ \\
\hline \multirow{13}{*}{ 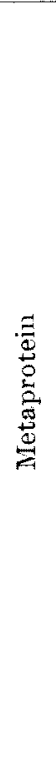 } & \multirow{3}{*}{23} & \multirow{3}{*}{8.0} & Soluble subs. & $\begin{array}{r}\mathrm{mg}_{1} \\
125.7\end{array}$ & $\begin{array}{r}\mathrm{mg} \\
12.70\end{array}$ & $\begin{array}{r}\% \\
10.1\end{array}$ & $\begin{array}{r}\mathrm{mg} \\
2.82\end{array}$ & $\begin{array}{r}\% \\
2.2\end{array}$ & $\begin{array}{r}\mathrm{mg} \\
24.22\end{array}$ & $\begin{array}{r}\% \\
19.3\end{array}$ & \begin{tabular}{r|}
$\mathrm{mg}$ \\
85.3
\end{tabular} & $\begin{array}{r}\% \\
67.9\end{array}$ \\
\hline & & & Metaprotein & 111.4 & 5.62 & 5.1 & - & - & 21.90 & 19.7 & 788 & 70.7 \\
\hline & & & Proteose & 127.8 & 7.40 & 5.8 & 5.20 & 4.1 & 34.15 & 26.7 & 81.0 & 63.4 \\
\hline & \multirow{5}{*}{24} & \multirow{5}{*}{5.1} & Insol. subs. & 100.8 & 4.47 & 4.4 & 6.18 & 6.1 & 21.88 & 21.8 & 67.5 & 67.0 \\
\hline & & & Soluble subs. & 96.6 & 10.77 & 4.4 & 3.27 & 3.4 & 18.65 & 19.3 & 61.8 & 64.0 \\
\hline & & & Metaprotein & 77.2 & 4.20 & 5.4 & 4.66 & 6.0 & 16.10 & 20.9 & 50.2 & 65.0 \\
\hline & & & Proteose & 179.9 & 10.18 & 5.7 & 4.10 & 2.3 & 53.05 & 29.5 & 113.6 & 63.2 \\
\hline & & & Peptone & 133.1 & 36.60 & 23.7 & 1.64 & 1.2 & 13.90 & 104 & 82.4 & 61.9 \\
\hline & \multirow{5}{*}{25} & \multirow{5}{*}{2.0} & Insol. subs. & 119.0 & 4.67 & 3.9 & 7.86 & 6.6 & 18.70 & 15.7 & 86.0 & 72.3 \\
\hline & & & Soluble subs. & 102.2 & 12.43 & 12.2 & 2.26 & 2.2 & 23.44 & 22.9 & 63.5 & 62.1 \\
\hline & & & Metaprotein & 40.6 & 1.60 & 3.9 & 2.53 & 6.2 & 9.00 & 22.2 & 27.2 & 70.0 \\
\hline & & & Proteose & 130.4 & 5.59 & 4.2 & 2.45 & 1.7 & 39.52 & 30.3 & 83.0 & 63.7 \\
\hline & & & Peptone & 146.3 & 41.05 & 28.1 & 1.86 & 1.3 & 24.70 & 16.9 & 77.2 & 52.7 \\
\hline \multirow{6}{*}{ 范 } & \multirow{2}{*}{26} & \multirow{2}{*}{8.4} & Proteose & 99.7 & 7.63 & 7.7 & 3.14 & 3.2 & 22.78 & 22.9 & 65.2 & 65.4 \\
\hline & & & Peptone & 96.5 & 21.72 & 22.5 & 1.55 & 1.6 & 15.70 & 16.3 & 56.4 & 58.5 \\
\hline & \multirow{2}{*}{27} & \multirow{2}{*}{4.8} & Proteose & 106.6 & 7.00 & 6.6 & 2.70 & $2 . \overline{0}$ & 23.95 & 22.5 & 66.3 & 62.7 \\
\hline & & & Peptone & 78.4 & 16.25 & 20.7 & 1.12 & 1.4 & 16.15 & 20.6 & 44.0 & 56.1 \\
\hline & \multirow{2}{*}{28} & \multirow{2}{*}{1.8} & Proteose & 81.5 & 3.80 & 4.7 & 1.48 & 1.8 & 19.80 & 24.4 & 54.9 & 67.4 \\
\hline & & & Peptone & 90.3 & 16.60 & 17.9 & 2.07 & 2.2 & 21.6 & 23.2 & 49.0 & 51.5 \\
\hline
\end{tabular}

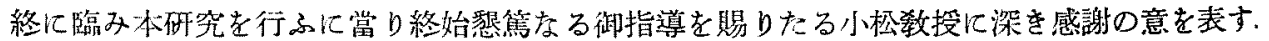

（昭和八年三月＼cjkstart京都帝國大學理學部有機生物化學教室） 